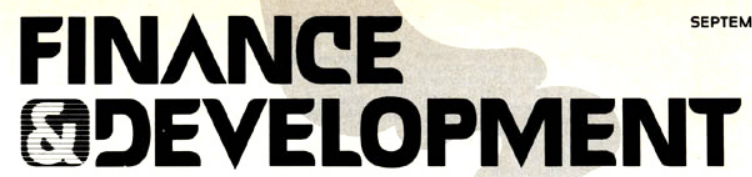

A QUARTERLY PUBLICATION OF THE INTERNATIONAL MONETARY FUND AND THE WORLD BANK

\title{
industrialization and trade
}


EDEVELOPMENT is published quarterly in English, Arabic Chinese, French, German, Portuguese, and Spanish by the International Monetary Fund and the International Bank for Reconstruction and Development, Washington, DC 20431, USA (USPS 123-250). Second class postage is paid at Washington, DC and at additional mailing offices. - English edition printed at Lancaster Press, Lancaster, PA. - English edition ISSN 0015-1947. - Opinions expressed in articles and other material are those of the authors; they do not necessarily reflect Fund or Bank policy. - New readers who wish to receive Finance \& Development regularly should apply in writing to Finance \& Development, International Monetary Fund, Washington DC 20431 USA, specifying the language edition and briefly stating the reasons for their request. - The contents of Finance \& Development are indexed in Business Periodicals Index, Public Affairs Information Service (PAIS), and Bibliographie Internationale des Sciences Sociales. An annual index of articles and book reviews is carried in the December issue.
Bahram Nowzad EDITOR

Shuja Nawaz MANAGING EDITOR

Rachel Weaving ASSISTANT EDITOR

Maxine Stough ASSISTANT EDITOR

Richard Stoddard ART EDITOR
ADVISORS TO THE EDITOR

Mark Allen

Vinod Dubey

Gregory Ingram

Paul Isenman

Arturo Israel

Anthony Lanyi

Claudio Loser

J.C. Peter Richardson

Alexander Shakow

Alan Tait

U Tun Wai

David Williams
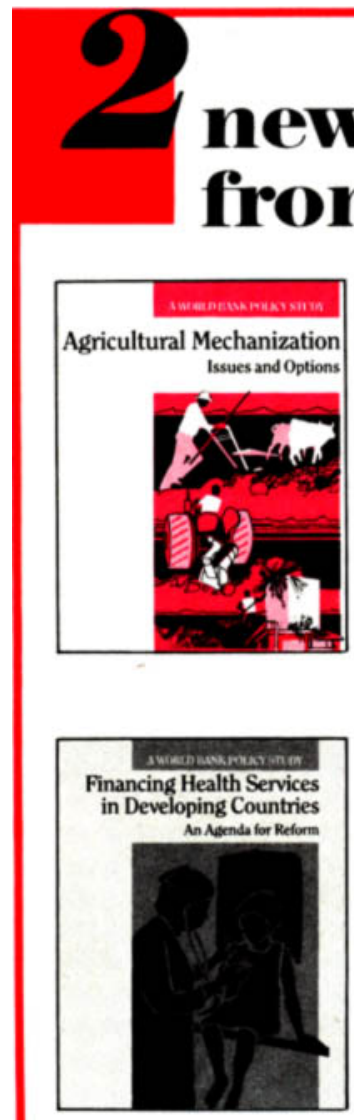

\section{Agricultural Mechanization: Issues and Options}

Analyzes patterns of mechanization and explores its effects on efficiency. Discusses the distortions introduced when policies encourage high capital-labor ratios and accelerate mechanization too rapidly. Includes recommendations for developing countries to bring their mechanization policies in line with overall development objectives. 90 pages/81/2/2 x 11/ISBN 0-8213-0903-X/US\$7.50

\section{Financing Health Services in Developing Countries: An Agenda for Reform}

Proposes an alternative approach to financing health care: relieve government of the burden of spending public resources on health care for the rich in order to make more public resources available for the poor. Draws on examples from World Bank experience to illustrate the successful application of policy alternatives in various countries.

104 pages/81/2 x 11/ISBN 0-8213-0900-5/US\$7.50

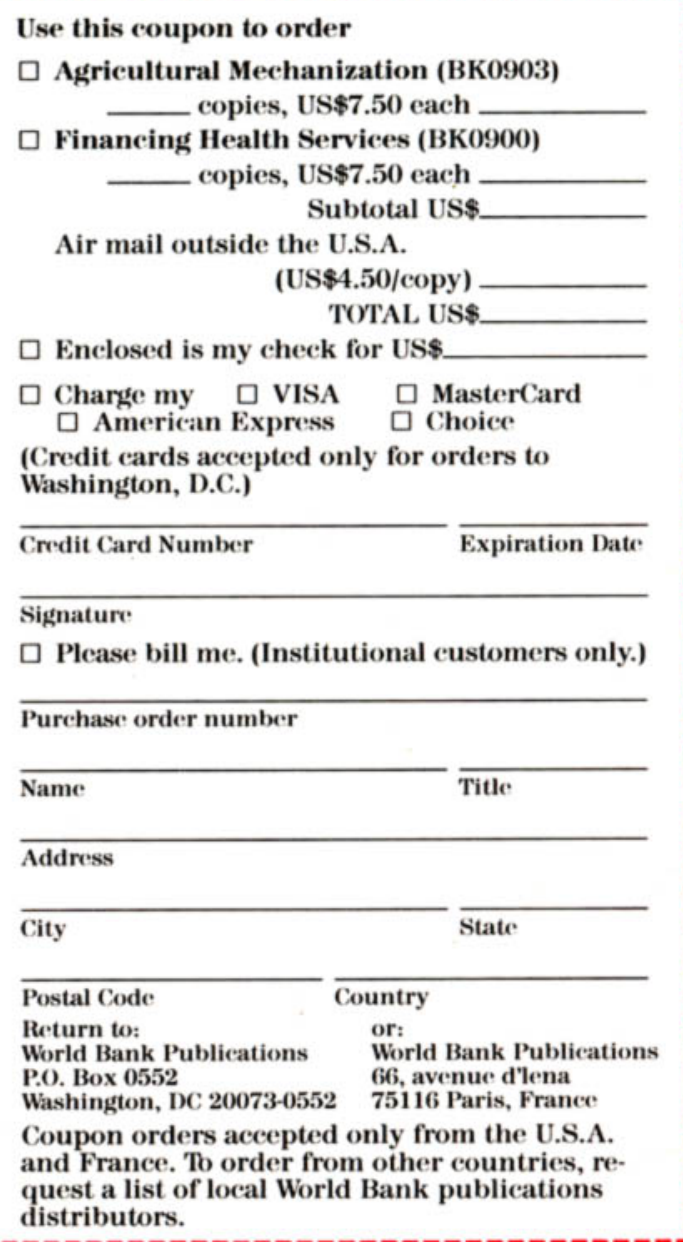


World Development Report 198

Industrialization and Foreign Trade

Critical issues in their inter-relationship and effects on growth

Adjustment at Work

Enhancing the Fund's Structural Adjustment Facility

Charles Gardner

6

Turkey's Adjustment Experience, 1980-85

George Kopits

National success bolstered by international assistance

Growth and Adjustment in South Asia

Bijan Aghevli, In-Su Kim, 12

Lessons from four countries

Trade Liberalization in Chile and Hubert Neiss

The anatomy of a major reform effort

WDR 1987

Structural Adjustment in Nigeria

Nils Borje Tallroth

Widespread reform in progress; the challenge ahead

Raising Resources for IDA: the Eighth Replenishment

Alexander Fleming and

23

Changes in key policies; higher financing Mary Oakes Smith

Issues in Capital Flows to Developing Countries

Anthony Lanyi

Factors affecting supply and demand in the 1980s

Financial Liberalization in Developing Countries

Michael Dooley and

Improving inefficient financial markets

Donald Mathieson

The European Community: On the Road to Integration

Augusto Lopez-Claros

The first 30 years; future prospects

\section{Managing the Budget}

A. Premchand

The US budget process explained

Why the World Current Account Does Not Balance

$\ldots$ and how to improve global accounting systems

\section{World Bank Reorganization}

World Economy in Transition

Pattern of central government outlays 1972-84

\section{Books}

Toward World Prosperity by Irving Friedman

Monetarism and Liberalization by Sebastian Edwards \& Alexandra Cox Edwards

The Keynesian Revolution and its Critics by Gordon A. Fletcher

Elitism and Meritocracy in Developing Countries by Robert Klitgaard

Multinationals of the South edited by Khushi M Khan, and

Multinationals, Governments and International Technology Transfer edited by A.E. Safarian and Gilles Y. Bertin

Macro-Policies for Appropriate Technology in Developing Countries edited by Frances Stewart

Books in Brief

Anthony Lanvi

Claudin Loser

Bahram Nowzad

Stephen Hevneman

Saniava Lall

Graeme Donovan

The Editor welcomes views and comments from readers on the contents of the journal.

The contents of Finance \& Development may be quoted or reproduced without further permission. Due acknowledgement is requested 


\title{
Industrialization and Foreign Trade
}

\section{What is the relationship between industrialization, trade, and economic performance?}

\author{
Sarath Rajapatirana
}

I n the first decades following World War II, economists viewed industrialization as an essential stage in reaching rapid economic development. But the real question is not how fast an economy can industrialize but how its industrial sector can be structured to support sustained growth. In other words, the aim is to seek ways of achieving efficient industrialization. This quest for efficient industrialization relates directly to foreign trade. Foreign trade allows countries to realize gains by subjecting domestic production to foreign competition and by providing access to a wider market to achieve economies of scale. At the national level, trade has allowed countries to specialize between industry and other sectors, between different branches of industry, and increasingly even between different stages in production. Trade has provided access to critical industrial inputs, including technology, for countries incapable of producing them. In turn, the advent of new technologies has shaped the pattern of specialization, and hence the pattern of trade. Trade has also meant expanded demand for exports which itself can spur technological development, and thus smooth the way for industrialization.

This article, based on the World Development Report, 1987, (see box on publication) examines three critical issues in the relationship between industrialization and foreign trade. These are:

- Factors that determine the pace and efficiency of industrialization, in particular the role of the government in that process.

- The impact of different trade strategies on industrialization and economic performance in developing countries.

- Lessons from trade policy reforms.

\section{Factors in industrialization}

There has been no single path to industrialization. It involves the interaction of technology, specialization, and trade, bringing about structural change within economies and leading to high investment and employment. At the heart of the process has been the role of the government in influencing both the pace and the efficiency of industrialization. A broad view of the history of industrialization reveals five factors that have shaped this process.

Initial conditions. A country with a large domestic market is in a better position to establish industrial plants that take advantage of economies of scale. Since distance between countries in many cases confers natural protection to domestic firms, everything else being equal, a country with a larger domestic market, in terms of area and population, can begin industrializing earlier than one with a smaller domestic market. But size is not the only factor necessary for industrialization, as shown by the cases of Japan and the United Kingdom. A rich endowment of natural resources may provide a country with the financial means to import foreign technology and its high income level may support a large domestic market for industrial products.

The World Development Report 1987 was prepared by a team led by Sarath Rajapatirana and comprising Yaw Ansu, Thorkild Juncker, Alasdair MacBean, Chong-Hyun Nam, Vikram Nehru, and Geoffrey Shepherd. The Bank's Economic Analysis and Projections Department, prepared the main projections and statistical materials. Anne O. Krueger played a principal role in the initial stages of the preparation of the Report. The work was carried out under the general direction of Benjamin B. King and Constantine Michalopoulos.

For information on ordering copies, see advertisement on back cover.

Domestic and foreign trade policies. The transition from a primarily agricultural and trading economy to an industrial economy has required, at least in the initial stages, an increase in the skills of the labor force. More than general education is required, but high achievement at the frontiers of science is not necessary for this transition.

State support for technical education made significant contributions to French and German industrialization. The United States broadly emulated the German system, with government financial support for research in universities. Private industry also maintained research laboratories that sometimes received public support. In Japan today most industrial research is carried out within private firms, but in the early period of industrialization the government helped to promote technological change, for example by setting up demonstration factories that were later sold to the private sector.

Transport and communications. Transport and communications networks integrated domestic and foreign markets into the global economy, making it easier for exporters to compete. But transport and communications networks are very capital-intensive and therefore expensive during the early stages of industrialization. They demand direct or indirect government support.

A stable institutional and macroeconomic enoironment. Laws and institutions that allow markets to function efficiently-property rights, standardized weights and measures, patent laws, and so forth-have all helped to promote faster and efficient industrialization. Such laws and institutions help promote long-term investment and risk taking. Yet they should also be flexible enough to allow institutional innovation.

Industrialization, especially in its early stages, requires large investment in machines 
and infrastructure. Moreover, one of the most important means by which technological innovation has been incorporated in production has been investment in new machines. Macroeconomic policies in the countries that were industrializing in the nineteenth century encouraged domestic savings and foreign finance required for investment.

Role of government. Markets and governments complement each other on the path to industrialization. Markets, while effective in pricing and sifting through investments, are rarely perfect. Government must sometimes intervene to achieve an efficient outcome. First, governments have to set the "rules of the game" to define the use, ownership, and conditions of transfer of physical, financial, and intellectual assets. Irrespective of the type of economy-whether it favors private enterprise or is a command economy-these rules impinge on economic activity. The more they are certain, well defined, and well understood, the more smoothly the economy can function. When these rules are unclear, interpreted in unpredictable ways, and managed by a cumbersome bureaucracy, they raise the costs of doing business and thereby discourage the increase in the number of transactions that are essential for industrial specialization.

As experience has shown, governments must continue to be the main providers of certain services to facilitate industrialization:

- All governments play a dominant role in education, especially in providing the basic skills of literacy and numeracy that are vital to a modern industrial labor force.

- Most governments provide the physical infrastructure of industry: transport, communications, and power systems.

- Most governments provide economic information and regulate such standards as weights, measures, and safety at work.

- Governments in the industrial economies promote scientific and technological research.

- State-owned enterprises are often established to carry out some of these tasks.

Governments also intervene somewhat less directly in the running of their economies. This indirect role creates the policy environment. Trade policy, fiscal incentives, price controls, investment regulations, and financial and macroeconomic policies are the main instruments available to governments. Capital-market failures and externalities are the justifications most often cited for direct intervention. Capital market failures arise when entrepreneurs cannot borrow adequate amounts or at opportunity costs that allow them to undertake investments. Externalities arise when the beneficial effects of an investment cannot be recouped by the in- vestor himself. Both concepts have been used, for example, to defend policies toward new, or "infant" industries.

Different forms of intervention will have different effects on the economy. Indeed, in most cases the important question often is not whether to intervene, but how. Quantitative restrictions on imports, for example, may be used to protect domestic infant industries. But these will raise social costs more than a tariff, because they encourage unproductive activities and may lead producers to avoid the controls. Tariffs, on the other hand, raise prices to consumers. Subsidies to the infant industry could give the same assistance without raising prices-but they raise public spending and add to budgetary deficits.

\section{Trade, industry, and growth}

Economists and policymakers in the developing countries have long agreed on the role of government in providing infrastructure, promoting market efficiency, and maintaining stable macroeconomic policies. But they have disagreed on trade strategies that have enabled countries to attain high growth and develop their industrial potential

outwourd-and inward-oriented policies. Trade policies can be characterized as outward oriented or inward oriented. An outwardoriented strategy provides incentives which are neutral between production for the domestic market and exports. Because international trade is not positively discouraged, this approach is often, though somewhat misleadingly, referred to as export promotion. In fact, the essence of an outward-oriented strategy is neither discrimination in favor of exports nor bias against import substitution. An inward-oriented strategy, on the other hand, is one in which trade and industrial incentives are biased in favor of domestic production and against foreign trade. This approach is often referred to as an importsubstitution strategy.

An inward-oriented strategy usually involves overt and high protection. This makes exports uncompetitive by raising the costs of the foreign inputs used in their production. Moreover, an increase in the relative costs of domestic inputs may also occur through inflation-or because of an appreciation of the exchange rate-as the quantitative import restrictions are introduced. Industrial incentives are administered by an elaborate and extensive bureaucracy.

Outward-oriented policies favor tariffs over quantitative restrictions. These tariffs are usually counterbalanced by other measures, including production subsidies and the provision of inputs at free trade prices. Governments seek to keep the exchange rate at a level that maintains equal incentives to produce exports and import substitutes. Overall protection is lower under an outwardoriented strategy than under inward orientation; equally important, the spread between the highest and lowest rates of protection is narrower.

Which policy has fostered greater success? An analysis of 41 economies by Bank staff explored the relationship over 1963-85 of trade strategies to economic performance. The results of the study indicate that outward-oriented economies have performed better than inward-oriented ones (see chart).

Some economies which did not fall clearly in either the outward- or inward-oriented category showed mixed results. There was no strictly discernible relationship between trade orientation and economic and industrial performance. This is not surprising, since factors other than trade strategy influence economic performance.

\section{Lessons of policy reforms}

If outward-oriented strategies are associated with better economic performance than inward-oriented strategies, why are policymakers in developing countries generally hesitant to undertake trade policy reforms to achieve such strategies? One reason is that there are many unresolved issues in the area of trade reform that economic research is only just beginning to answer. Another is that many trade reforms have had to be reversed, leading to the perception that they entail high costs and produce limited benefits.

The shift toward outward orientation inevitably involves transitional costs. Major shifts in resources accompany trade reforms aimed at liberalizing the trade regime, as some activities contract and others expand in response to the changes in prices. If the economy is highly distorted to begin with, the changes that are likely to be necessary are very large. One visible cost is increased unemployment, though recent research on trade reform shows that this is more the result of poor macroeconomic policies than of the trade reforms themselves.

More often than not, trade liberalization comes in the wake of economic crises, usually associated with budget and balance of payments deficits and inflation. Such crises may create the political will for change-an important ingredient for undertaking trade reforms -but reforms undertaken in a crisis atmosphere may not be sustainable. So a government's long-term commitment to reform needs to be substantial and credible if economic agents are to respond to the incentives the reform creates. Moreover, a strong initial shift in policy can quickly boost exports, enough to create vested interests in support of further liberalization. Stable 

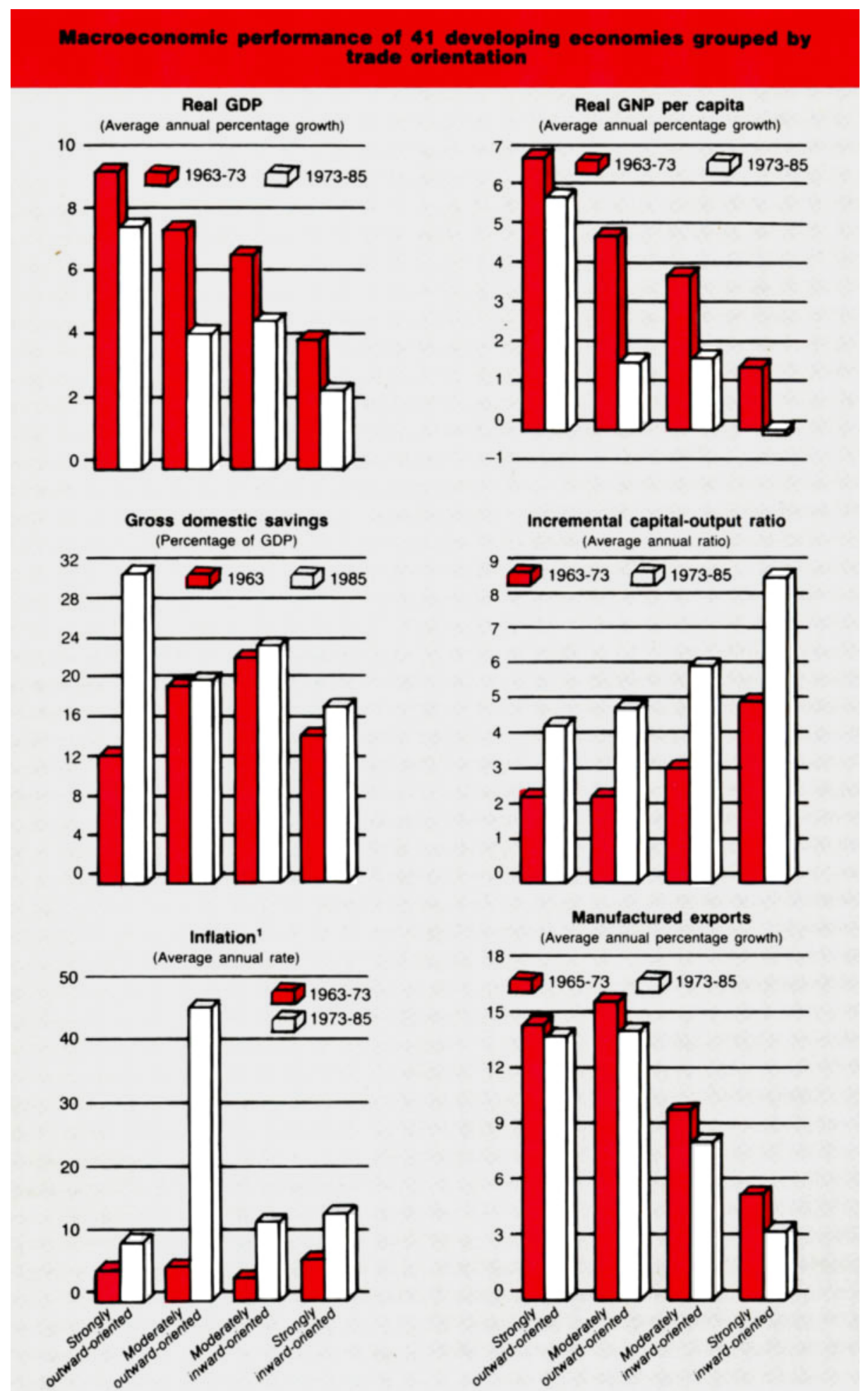

Note: Averages are weighted by each country's share in the group total for each indicator inflation rates are measured by the implicit GDP deflator. Values are group medians

macroeconomic policies, to reduce inflation and prevent currency appreciation, are also crucial for the success of trade reforms. The fate of the reforms, once undertaken, often rests mainly with what happens to the balance of payments-and this is determined by macroeconomic policy.

Experience suggests that export per-
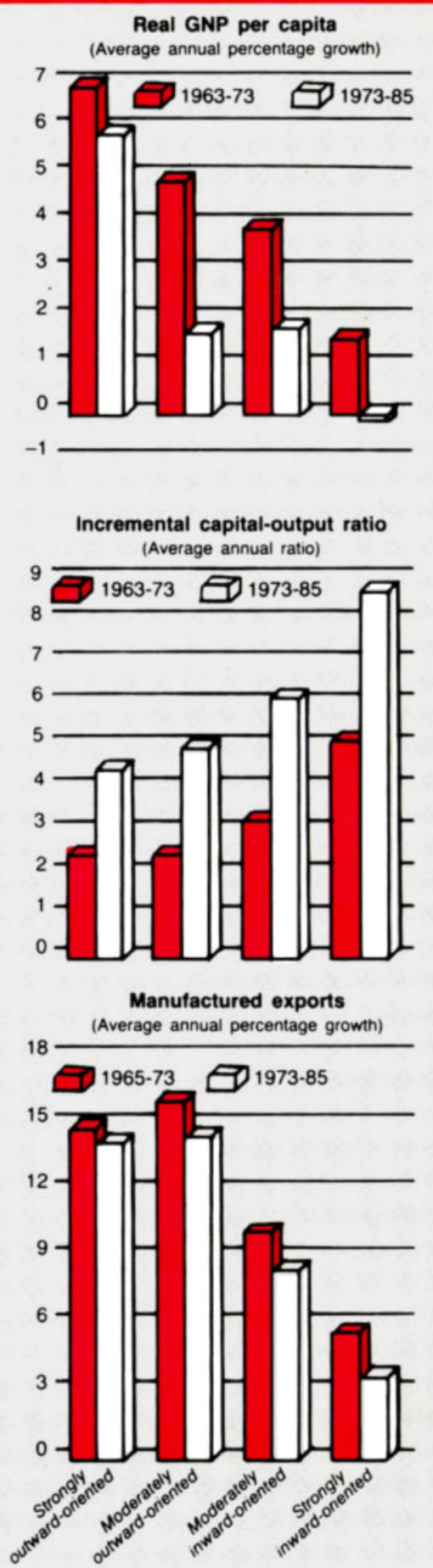

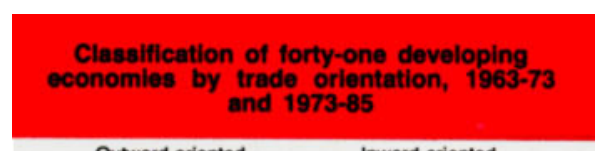

\begin{tabular}{|c|c|c|c|}
\hline \multicolumn{2}{|c|}{ Outward-oriented } & \multicolumn{2}{|c|}{ Inward-oriented } \\
\hline Strongly & Moderately & Moderately & Strongly \\
\hline \multicolumn{4}{|c|}{$1963-73$} \\
\hline $\begin{array}{l}\text { Hong Kong } \\
\text { Korea, } \\
\text { Rep. of } \\
\text { Singapore }\end{array}$ & $\begin{array}{l}\text { Brazil } \\
\text { Cameroon } \\
\text { Colombia } \\
\text { Costa Rica } \\
\text { Cote d'lvoire } \\
\text { Guatemala } \\
\text { Indonesia } \\
\text { Israeel } \\
\text { Malaysia } \\
\text { Thailand }\end{array}$ & $\begin{array}{l}\text { Bolivia } \\
\text { El Salvador } \\
\text { Honduras } \\
\text { Kenya } \\
\text { Madagascar } \\
\text { Mexico } \\
\text { Nicaragua } \\
\text { Nigeria } \\
\text { Philippines } \\
\text { Senegal } \\
\text { Tunisia } \\
\text { Yugosivia }\end{array}$ & $\begin{array}{l}\text { Argentina } \\
\text { Bangladesh } \\
\text { Burundi } \\
\text { Chile } \\
\text { Dorninican Rep. } \\
\text { Ethiopia } \\
\text { Ghana } \\
\text { India } \\
\text { Pakistan } \\
\text { Peru } \\
\text { Sri Lanka } \\
\text { Sudan } \\
\text { Tanzania } \\
\text { Turkey } \\
\text { Uruguay } \\
\text { Zambia }\end{array}$ \\
\hline \multicolumn{4}{|c|}{$1973-85$} \\
\hline $\begin{array}{l}\text { Hong Kong } \\
\text { Korea, } \\
\text { Rep. of } \\
\text { Singapore }\end{array}$ & $\begin{array}{l}\text { Brazil } \\
\text { Chile } \\
\text { Israel } \\
\text { Malaysia } \\
\text { Thailand } \\
\text { Tunisia } \\
\text { Turkey } \\
\text { Uruguay }\end{array}$ & $\begin{array}{l}\text { Cameroon } \\
\text { Colombia } \\
\text { Costa Rica } \\
\text { Cote d"lvoire } \\
\text { El Salvador } \\
\text { Guatemala } \\
\text { Honduras } \\
\text { Indonesia } \\
\text { Kenya } \\
\text { Mexico } \\
\text { Nicaragua } \\
\text { Pakistan } \\
\text { Philippines } \\
\text { Senegal } \\
\text { Sri Lanka } \\
\text { Yugoslavia }\end{array}$ & $\begin{array}{l}\text { Argentina } \\
\text { Bangladesh } \\
\text { Bolivia } \\
\text { Burundi } \\
\text { Dominican Rep. } \\
\text { Ethiopia } \\
\text { Ghana } \\
\text { India } \\
\text { Madagascar } \\
\text { Nigeria } \\
\text { Peru } \\
\text { Sudan } \\
\text { Tanzania } \\
\text { Zambia }\end{array}$ \\
\hline
\end{tabular}

offset the incentives for increasing the production of exports and import substitutes. Large capital inflows were in some cases the result of an ill-timed or uncoordinated liberalization of the financial markets in which domestic interest rates rose very sharply. This provoked heavy borrowing from abroad. Thus, poor macroeconomic policy was more to blame than the trade reforms for the crisis that followed. Trade reforms, however, fell into some disrepute because of their guilt-byassociation with poor macroeconomic policies.

The design of trade policy reform. A review of the recent history of trade policy reform suggests that three elements seem to matter most in the design of such efforts. The first is the move from quantitative restrictions to tariffs. This links domestic prices to foreign prices and allows greater access to foreign inputs while increasing competition. The second is the narrowing of the variation in rates of protection even as its overall level is reduced. The third is direct promotion of exports to offset the effects of import tariffs. Specific measures to promote exports risk acquiring a permanent status, however, and lead to the postponement of more fundamental changes relating to the exchange rate. They also contravene rules of the General Agreement on Tariffs and Trade (GATT), create domestic lobbies that will oppose their removal, and risk countervailing duties from trading partners.

Trade reforms alone cannot lead to efficient industrialization and improved economic performance without addressing a number of 


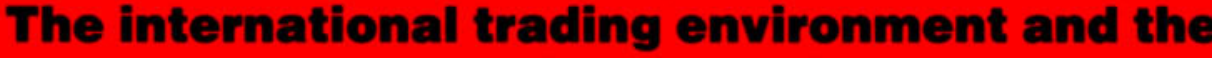 developing countries}

While the lessons from trade policy reforms show that the process is manageable under certain conditions, the benefits from trade liberalization can be -increased if the world trading environment is free. Such an environment will also make it politically viable for developing countries to undertake trade reforms. But in recent years there has been a resurgence of protection in the form of nontariff barriers. The proportion of North American and European Community imports affected by various nontariff restrictions has risen by more than 20 percent from 1981 to 1986 . These restrictions cover large volumes of imports and particularly affect exports of developing countries. Nontariff barriers in clothing and footwear have proved porous, so some developing countries have been able to increase their exports to the industrial economies even as gaps in these barriers are being plugged.

Costs of protection to industrial countries

There are several ways of measuring the costs of protection. These methods generally underestimate the costs due to the negative effects of restraining competition on managerial efficiency, acquisition of new techniques, economies of scale, and savings and investments.

- Costs to the consumers. Protection of apparel in the United States is estimated to have cost US companies in 1984 between $\$ 8.5$ billion and $\$ 18.0$ billion; of steel, between $\$ 7.3$ billion and $\$ 20$ billion; and of automobiles, around $\$ 1.1$ billion.

- Welfare costs. This concept covers the extra cost to the economy as a whole of producing more of the goods domestically rather than importing them. Normally the welfare cost is considerably less than the consumer cost--particularly for tariffs or quotas. Even so, the estimates for textiles and apparel range from $\$ 1.4$ billion to $\$ 6.6$ billion in the European Community and the United States and nearly $\$ 2$ billion for steel in the United States.

- The cost of preserving a job. Each protected job often ends up costing consumers more than the worker's salary. For example, each job preserved in the automobile industry in Britain is estimated to have cost consumers between $\$ 19,000$ and $\$ 48,000$ a year. In the United States the cost was between $\$ 40,000$ and $\$ 108,500$ a year. Looked at another way, the cost to consumers of preserving one worker in automobile production in the United Kingdom was equivalent to four workers earning the average industrial wage in other industries. In the US automobile industry, the equivalent cost would be the wages of six ordinary industrial workers. The voluntary export restraints by foreign steel producers cost US consumers $\$ 114,000$ per protected job each year.

\section{Costs to developing countries}

Developing countries bear heavy costs emerging from their own highly protective policy environments. But they also suffer costs from the protection in industrial countries.

Few studies exist of the latter. The available studies attempt to measure only the increase in export earnings for developing countries that would arise from reductions in the tariffs and nontariff barriers which face them. Studies by the World Bank, the Fund, and the Commonwealth Secretariat show that the result would be substantial export gains-worth several billion dollars a year. More detailed studies have been made for individual countries such as the Republic of Korea. Restrictions on Korean exports of carbon steel cut sales to the United States by 33 percent, or $\$ 211$ million; but Korea had offsetting gains in the form of higher prices and increased sales to other markets.

The costs of protection are high for both industrial and developing countries. They bear heavily on the latter, however. Protective structures in industrial countries discriminate more against developing countries than each other.

\section{The international environment}

Given their high unemployment, slowing growth, and the increased competition that they face from developing countries manufactures, there is the danger that industrial countries will increase barriers to manufactures from developing countries. This may mean more discriminatory nontariff barriers, more effectively administered. Such steps would further undermine the integrity of the GATT system and would restrict the growth of exports from developing countries. Many developing countries are already heavily in debt, so a reduction in their export earnings would aggravate the problems of world debt. Protectionist acts will have very serious implications for resource growth and maintaining orderly foreign exchange and capital markets in the world. These developments could produce widespread disillusionment with the outward-oriented trade strategies which have proved so successful for the newly industrializing countries in recent years.

If industrial countries become more protectionist, developing countries would be forced into exploring other, second-best, options. These would include trying to expand trade with the centrally planned economies and with other developing countries on a discriminatory basis. But the prospects of greatly improved trade in either of these directions are not good. Neither could replace trade with the industrial market economies. areas that constrain domestic supply response. Among these, four areas are particularly important.

- Reduction of price controls. Such controls are pervasive in developing countries and are usually aimed at protecting consumers from monopolies and helping industry by restraining increases in prices of inputs. They restrict supply and distort relative prices, however, causing inefficiency and retarding indoustrial growth.

- Investment licensing regulations. These regulations are imposed to influence the pattern of private investment in line with government priorities. If designed poorly, however, they distort patterns of prices and incentives, discourage foreign private investment, and encourage foreign investments, if any, in activities with low social returns.
- Financial market reforms. Interest rate and portfolio controls can discourage savings and distort investment patterns. Reforms are needed to let resources move from one activity to another in line with the incentives created by trade reforms.

- Labor market reforms. Some of these regulations also distort factor prices, technology choices, and lead to lower employment. Labor market flexibility is also an important ingredient in trade reform.

The combination of trade and domestic market reforms can make countries move from inward-oriented to outward-oriented trade strategies. This, of course, presupposes that the other ingredients of industrialization and growth--physical infrastructure, education, and legal and institutional factors--are adequate for the task. But benefits from trade reforms can be increased only if the international trading environment is freer than it is now (see box) and protection is both low and relies more on price measures than quantitative restrictions.

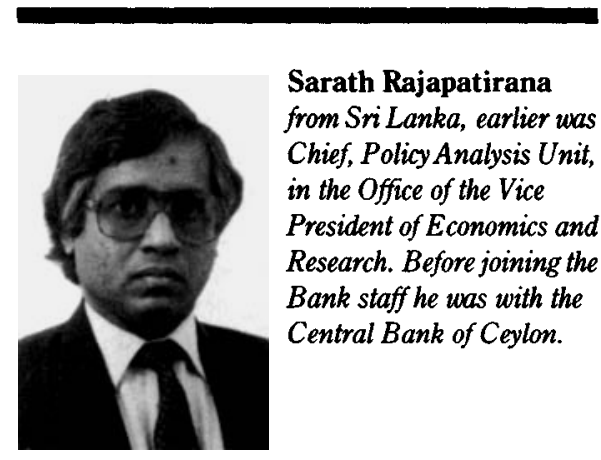

Finance \& Development / September 1987 


\title{
8 \\ Enhancing the Fund's Structural Adjustment Facility
}

\author{
Charles S. Gardner \\ Deputy Director, Extermal Relations Department, IMF
}

In n its April 1987 meeting, the Fund's Interim Committee highlighted the plight of the low-income countries, and outlined a strategy for their recovery. It emphasized that it is crucial for these countries to implement reforms which, to be fully effective, will need to be accompanied by the timely provision of additional financing on appropriate concessional terms to support these reforms. The Committee also called upon creditor governments to grant exceptional relief with respect to official credits in highly indebted low-income countries including, in particular, Sub-Saharan Africa, where such relief is necessary to support and encourage far-reaching economic reforms.

In calling for more finance from bilateral and multilateral donors, the Committee emphasized the catalytic role of the Fund's new Structural Adjustment Facility (SAF), under which a number of arrangements with SAFeligible countries have now been put in place to support growth-oriented adjustment efforts.

The Managing Director of the Fund, Michel Camdessus, has proposed a tripling in SAF resources for the three years $1988-90$ to a total of SDR 9 billion (about $\$ 11.5$ billion at current exchange rates). In their economic summit meeting in Venice, the heads of state or government of the seven major industrial countries and the representative of the European Community recognized that the "uniquely difficult" problems of some of the poorest countries, primarily in Sub-Saharan Africa, need special treatment. In this connection, they welcomed the proposal for a significant increase in the resources of the
SAF and urged the completion of related discussions before the end of 1987 . While encouraged by the support of the participants in the Venice meeting, Mr. Camdessus has emphasized his hope that all countries in a position to do so would add to SAF resources, and thus "show their solidarity with countries poorer than themselves."

\section{Establishment of the SAF}

The SAF was established by the Fund's Executive Board in March 1986 to provide financial assistance on concessional terms in support of the balance of payments adjustment efforts of eligible countries. SAF loans are provided at an interest rate of $1 / 2$ of 1 percent annually, and have a repayment period of $51 / 2-10$ years. Financing under the Fund's other facilities has market-related interest rates and repayment periods ranging from 3-5 years up to 4-10 years. The first arrangement under the SAF (for Burundi) was approved in August 1986. As of end-June 1987, SAF arrangements involving commitments of some SDR 777 million had been concluded with 15 countries. Discussions are under way, and in some cases quite advanced, with many of the remaining 47 eligible countries.

Eligibility for the SAF is confined to low-income countries. SAF loans are provided to countries facing protracted balance of payments problems in support of their medium-term programs of macroeconomic and structural adjustment aimed at fostering growth and strengthening the balance of payments position. The initial financing for the SAF was provided by repayments of Trust
Fund loans, which are scheduled to continue to be received by the Fund through April 1991. The original Trust Fund loans, made in 1976-81 to 55 low-income developing countries, had been financed from part of the proceeds of the sale of some of the Fund's gold holdings and by contributions from a number of donor countries.

Loans under the SAF are made in proportion to a member's quota in the Fund. For the benefit of other eligible countries with lower quotas, the two eligible countries with the largest quotas, China and India, have indicated that they do not intend to avail themselves of the facility. As a result, the Executive Board was able at the time the SAF was established to authorize SAF loans equivalent to 47 percent of a country's quota. The loans would be made over the three-year period of a SAF arrangement, with 20 percent of quota to be disbursed in the first year and 13.5 percent in each of the second and third years. Recently, the Board reviewed the first year's experience with the SAF, and decided to enlarge the three-year total access to 63.5 percent of quota and to raise the amount available to a member during the second year of the three-year arrangement to 30 percent of quota. These increases were based on expected Trust Fund repayments and interest earned and do not take into account the increase in SAF resources that has been proposed by $\mathrm{Mr}$. Camdessus.

\section{Innovative features}

The SAF was conceived with at least three major innovative features. First, SAF arrangements require a comprehensive three-year 
policy framework which incorporates more explicitly than in most previous Fund facilities the structural policy elements of a member's reform program. Second, the process of collaboration with the World Bank was formalized through the requirement of joint assistance to a member country in the formulation of the policy framework paper (PFP) and of common negotiation of the final arrangement, as well as through involvement of the World Bank Executive Board in its review. Third, there was an expectation that the PFP and SAF process would be a catalyst for additional financial resources including, possibly, matching resources from the World Bank and associated resources from other multilateral and bilateral sources, over and above what would have been available in the absence of SAF-supported programs.

SAF programs approved so far have emphasized substantial increases in domestic investment, stressing an improvement in public sector finances and private sector savings. They have generally aimed for a higher rate of growth over the three years of the arrangement than the country had been achieving. On structural reform, all programs have aimed to improve productivity and the financial viability of public investment projects. Typically, SAF programs include tax

\begin{tabular}{|c|c|c|c|}
\hline \multicolumn{4}{|c|}{$\begin{array}{l}\text { Structural Adjustment Facility arrangements, } \\
\text { as of June 30, } 1987 \\
\text { (In millions of SDRs) }\end{array}$} \\
\hline Member & $\begin{array}{l}\text { Date of } \\
\text { three-year } \\
\text { arrangement }\end{array}$ & $\begin{array}{c}\text { Total } \\
\text { amount }\end{array}$ & $\begin{array}{l}\text { Amount } \\
\text { drawn' }\end{array}$ \\
\hline Bangladesh & Feb. 6, 1987 & 182.56 & 57.50 \\
\hline Bolivia & Dec. 15,1986 & 57.59 & 18.14 \\
\hline Burundi & Aug. 8, 1986 & 27.11 & 8.54 \\
\hline Central African Republic & June 3,1987 & 19.30 & 6.08 \\
\hline Dominica & Nov. 26, 1986 & 2.54 & 0.80 \\
\hline The Gambia & Sept. 17, 1986 & 10.86 & 3.42 \\
\hline Haiti & Dec. 17,1986 & 28.00 & 8.82 \\
\hline Mauritania & Sept. 22, 1986 & 21.53 & 6.78 \\
\hline \multicolumn{4}{|l|}{ Mozambique, People's } \\
\hline Republic of & June 9, 1987 & 38.73 & 12.20 \\
\hline Niger & Nov. 17,1986 & 21.40 & 6.74 \\
\hline Senegal & Nov. 10, 1986 & 54.04 & 17.02 \\
\hline Sierra Leone & Nov. 14,1986 & 36.77 & 11.58 \\
\hline Somalia & June 30, 1987 & 28.07 & 8.84 \\
\hline Uganda & June 17,1987 & 63.25 & 19.92 \\
\hline Zaïre & May 15,1987 & 184.78 & 58.20 \\
\hline Total & & 776.53 & 244.58 \\
\hline
\end{tabular}

Source: IMF.
'The amounts drawn are 20 percent of the member's quota, from present total access amounting to 63.5 percent of quota. Access limits will be reviewed again by May 31,1988 .
The amo and public enterprise reform, improvement of the agricultural sector, and strengthening of pricing policies, as well as trade liberalization and tariff reform, and civil service and financial sector reforms.

The effort to improve the integration of macroeconomic and structural policies under SAF programs involves close collaboration between the Fund and the Bank, to assist borrowing countries in formulating their medium-term strategies for achieving improved growth with substantial progress toward a viable balance of payments position over the three-year SAF period. As part of the SAF process, policy framework papers are developed by member countries with the help of the staffs of the Fund and the Bank, and reviewed by the Executive Boards of both the Fund and the Bank before specific lending arrangements are approved. Annual disbursements under the SAF are tied to approval of annual arrangements by the Fund's Executive Board, in light of the longer-term strategy articulated in the PFP and the more detailed objectives of the adjustment program for the year.

The catalytic role of the SAF process and associated activities has been enhanced by recent actions of the Paris Club creditors. Early in 1987, Paris Club creditors decided to tie reschedulings, on an exceptional and case-by-case basis, to SAF arrangements; the reschedulings for Mozambique and Uganda in June 1987 were the first such reschedulings. Also, in both instances, creditors agreed to go beyond the traditional terms by extending the rescheduling period.

\section{The Managing Director's initiative}

Mr. Camdessus has proposed a tripling of the resources available under the SAF to a total of SDR 9 billion. The resources currently available for lending in support of SAF arrangements, in his view, were insufficient in relation to the need to support with appropriate financing the adoption and pursuit by SAF-eligible member countries of strong growth-oriented adjustment programs. A tripling of SAF resources is estimated to be essential to cover these financing requirements, even after assuming generous Paris Club reschedulings, a continuation of growing bilateral aid flows, and a rapid implementation of the agreed eighth replenishment of the World Bank's International Development Association. A portion of the IDA replenishment of $\$ 12.4$ billion is intended to be used to support structural adjustment efforts. The Managing Director has emphasized the importance that the resources added to SAF be truly additional to currently available assistance, and that the terms be no less favorable than those on current SAF loans.

Addressing the annual meeting of the UN Economic and Social Council in Geneva in June 1987, Mr. Camdessus outlined the details and rationale of his proposal for the enhancement of the SAF. He observed that since becoming Managing Director in January, he had been struck not only by the efforts that many of the poorest countries have been seeking to make to adjust their economies, but also by the "truly daunting task that they face," given the deeply depressed prices for their exports and slow growth of their external markets, on top of their structural handicaps. The Managing Director warned that such difficulties were "leading governments in some of these countries to doubt the possibility of reversing these negative trends and making them increasingly reluctant to embark on forceful adjustment programs oriented to growth."

The SAF has the potential to be a catalyst for promoting programs of structural reform in the poorest countries, Mr. Camdessus told the ECOSOC session. Such programs are essential, he said, and it is therefore imperative that the international community give renewed hope to these countries by showing its willingness to provide increased aid and exceptional financial help in support of their efforts to strengthen their economies. 


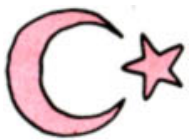 \\ Turkey's \\ Adjustment Experience, 1980-85}

\section{Economic growth and stabilization, achieved through outward-looking policies, implemented in a favorable sociopolitical climate and supported by external assistance on a large scale}

\section{George Kopits}

B eset by a severe economic crisis, social unrest, and political instability, in 1980 Turkey launched a far-reaching stabilization and structural reform effort, which set the stage for a rapid export-led economic recovery and a significant correction of external and domestic imbalances. Although not yet completed, the Turkish adjustment-traced through 1985 in the present articleillustrates that the success of such an effort depends not only on the adequacy of economic policies but also on the sociopolitical climate and external assistance. In Turkey, on balance, these three fundamental criteria appear to have been met.

\section{Background}

In the early 1970s Turkey achieved rapid economic growth, while maintaining a moderate rate of inflation and a surplus in the external current account. In the wake of the first oil crisis, the government persevered with an ambitious inward-looking development strategy and sought to shelter the economy from the deterioration in the terms of trade. During 1973-76 the growth of real GNP averaged almost 8 percent a year, paced by an increase in real fixed investment of some 16 percent yearly. This was achieved, however, at the cost of mounting internal and external imbalances. The deterioration in public finances was particularly acute: in 1977 the public sector borrowing requirement had

This article draws on the author's Structural Reform, Stabilization, and Growth in Turkey, published by the Fund as Occasional Paper No. 52 (May 1987), price \$7.50. reached the equivalent of more than 11 percent of GNP, compared with 2 percent of GNP in 1973. Excess demand, fueled by expansionary fiscal and monetary policies, contributed to a considerable weakening in the balance of payments and to a rise in inflationary pressures. The current account moved from a surplus of $\$ 0.7$ billion in 1973 to a deficit of $\$ 3.1$ billion in 1977 , reflecting the sharp rise in the oil import bill coupled with stagnation in exports and workers' remittances. The deficits were financed mainly with short-term borrowing. With rapidly shrinking external reserves, Turkey became less and less able to meet mounting import and debt-service payments, which resulted in the accumulation of arrears and a virtual drying up of normal sources of financing.

In 1978-79 the authorities made several attempts to arrest the deterioration of economic conditions. In spite of debt reschedulings and the provision of some external assistance, these attempts met with little success. The operating losses of state economic enterprises (SEEs) rose sharply and the public sector borrowing requirement remained high. Wage settlements likewise were excessive. Adjustments of the exchange rate and interest rates, meanwhile, failed to keep up with a sharp acceleration in the rate of inflation; external competitiveness weakened further and financial disintermediation (whereby money assets were replaced by nonfinancial assets) proceeded apace. In these circumstances, the narrowing of the current account deficit by more than one half between 1977 and 1978-79 was forced by the lack of external financing and accomplished chiefly through a drastic curtailment of imports. In turn, widespread shortages of essential inputs led to a drop in industrial output and exacerbated the rate of inflation. In 1979, the average rate of inflation escalated to more than 70 percent, while real GNP fell for the first time in more than two decades.

Parallel with the economic deterioration, Turkey underwent a major political and social crisis. Weak left-of-center and right-of-center coalition governments rapidly succeeded one another, unable to cope with growing labor strife and urban terrorism.

\section{Sociopolitical conditions}

It was against this background that in January 1980 a two-month old minority government unveiled a comprehensive economic policy package based on an outwardand market-oriented approach, breaking with the inward-looking étatist strategy of the previous five decades. However, civil unrest continued through most of 1980 , as evidenced by close to 200 politically motivated murders a month, while labor negotiations became increasingly confrontational, often involving prolonged strikes and lockouts.

The breakdown of law and order was halted by a military takeover in September 1980 . From the outset, the military government endorsed the economic policies of the previous government (retaining key members of the former economic team) and announced its intention to return the country to civilian rule at the earliest opportunity. In November 1982, a new constitution was approved by referendum, and as mandated by the constitution, a president was elected for a sevenyear term with extensive authority. Despite some limitations on political parties and candidates, in November 1983 the first 
parliamentary elections were held since the advent of military rule. The new government -which since then has withstood additional electoral tests in the context of an apparently broader political participation-stepped up the pace of structural reform.

In spite of a temporary suspension of some civil liberties, in particular immediately after the military intervention, since September 1980 Turkey has enjoyed a considerable degree of political and social stability. Since its inception in January 1980, successive administrations-both civilian and militaryhave been firmly committed to the adjustment program, notwithstanding occasional slippages in implementation. Economic policies have been subject to intense public debate; however, except for groups adversely affected by certain measures, the program seems to have been supported, or at least tolerated, by large segments of the population.

\section{External assistance}

In support of the program, in June 1980 the Fund approved a three-year stand-by arrangement for SDR 1,250 million (625 percent of Turkey's quota at that time) which was fully utilized, followed by a one-year stand-by for SDR 225 million (75 percent of quota); the latter was cancelled and replaced in April 1984 by another arrangement of the same magnitude. In all, over the period 1980-85, the Fund made available SDR 1.7 billion (of which SDR 1.5 billion was utilized), while the World Bank extended $\$ 1.6$ billion in five consecutive structural adjustment loansbesides sizable project loans. Turkey also received concessional balance of payments credits in excess of $\$ 1.5$ billion from official sources, under the auspices of the Organisation for Economic Co-operation and Development (OECD) and from Saudi Arabia. Over the program period, balance of payments assistance from the Fund, the Bank, and bilateral sources totaled more than $\$ 5$ billion. In addition, more than $\$ 6.5$ billion in short-and medium-term obligations, including interest payments, falling due in 1980-84 (some of them restructured previously) were restructured through the OECD and by private creditors.

\section{Structural reform}

Domestic pricing. In 1980 the government freed private sector prices and sharply adjusted prices of basic commodities and services produced by SEEs and state monopolies. Except for a few items whose prices continued to be subsidized, SEEs were instructed to set prices on the basis of cost developments. Subsidies on agricultural products and inputs were also reduced considerably.
Interest rates. After several small increments, time deposit rates were decontrolled in July 1980, allowing commercial banks to determine rates by agreement among themselves. Since December 1983, the central bank has reviewed and set ceilings on deposit rates at least every three months taking into account fluctuations in the rate of inflation; on the lending side, banks were allowed to set nonpreferential rates freely. Since around mid-1981 and except for parts of 1983 and 1984, key time deposit and lending rates have been positive in real terms.

Wage determination. In September 1980 the authorities introduced an incomes policy that has been followed until the present. Centrally determined wage increases on the basis of yearly inflation targets-but lagging behind actual price developments-became mandatory for the public sector and have been used as guidelines in the private sector.

Exchange rate policy. Following a 33 percent devaluation of the Turkish lira in January 1980 , the central bank began to adjust the exchange rate with increasing frequency so as to compensate for differences in inflation rates at home and in major industrial partner countries; since May 1981 adjustments in the nominal rate have taken place daily. Over the 1981-85 period, the lira was depreciated in real terms on average by about 4 percent a year, although subject to some short-run fluctuations connected with efforts to dampen inflationary pressures--particularly in the later part of 1984.

Foreign trade and investment. By the end of the $1970 \mathrm{~s}$, Turkey had a highly restrictive import regime characterized by quotas, licensing, tariffs, tariff-like charges, and an advance deposit requirement. These restrictions were relaxed significantly in $1980-81$, and a further major liberalization took place in 1984 when most imports were freed from licensing. By the end of 1985, quantitative restrictions had been removed, many tariff rates were lowered, and deposit requirement rates reduced to a low level. Fiscal and financial export subsidies, which had been intensified in the initial phase of the adjustment program, were trimmed starting in 1984; also, export restrictions (licensing and price controls) were abolished in 1984. Restrictions on direct investment inflows were eased considerably.

Exchange and payments. Early in the program, most multiple currency practices and bilateral payments agreements were terminated, and foreign exchange regulations affecting commercial banks and exporters were eased. In January 1984, the exchange and payments system was liberalized in several important respects: domestic banks were allowed to engage in foreign exchange operations within broad limits; the surrender requirement was reduced substantially on export earnings; foreign exchange deposits, yielding market interest rates, could be opened and used without limits; and restrictions on foreign travel and other invisible transactions were eased and simplified.

Financial sector. Between 1983 and 1985, the liquidity and reserve requirement system was simplified and made more effective: legally required ratios were unified and lowered, the time period permitted for compliance was shortened, and interest payments on reserves were abolished. Preferential credit facilities were reduced. Major banking reform legislation was completed in April 1985, with provisions on capital requirements, contingency reserves, accounting and reporting standards, deposit insurance, branch banking, and ownership and management requirements. Also, a number of institutional measures were taken to develop capital markets.

Nonfinancial public enterprises. From the outset of the program, the authorities acted not only to adjust the prices of SEEs toward covering production costs, but also enforced a hiring freeze and slowdown of wage increases. The concomitant reduction in financing needs permitted a sharp cutback in bank lending and budgetary transfers to SEEs. In October 1983, the legal basis for SEE reform was established, requiring SEEs to be run along commercial lines. By the end of 1984, SEEs had lost almost all preferences accorded previously as regards taxes, tariffs, and credits. In May 1986, the government obtained legislative authority to sell SEEs to the private sector.

Tusution. In 1981, personal income tax brackets were raised sharply to compensate for inflation, while marginal tax rates were restructured providing for a gradual reduction of all rates over a four-year period. The corporation income tax was unified for all corporate taxpayers, including SEEs. In 1984, there were substantial cuts in the rates of withholding taxes on financial income and transactions. In January 1985, Turkey substituted a 10 percent value-added tax for production taxes and other duties.

\section{Demand management}

Whereas steady and significant progress was made in implementing structural measures, demand management was applied unevenly. Following a restrictive stance in 1981-82, financial policies were relaxed until 1985 when they became somewhat tighter again.

As a result both of expenditure restraint and of some rise in tax effort, the ratio of the consolidated central government budget deficit to GNP was more than halved between 


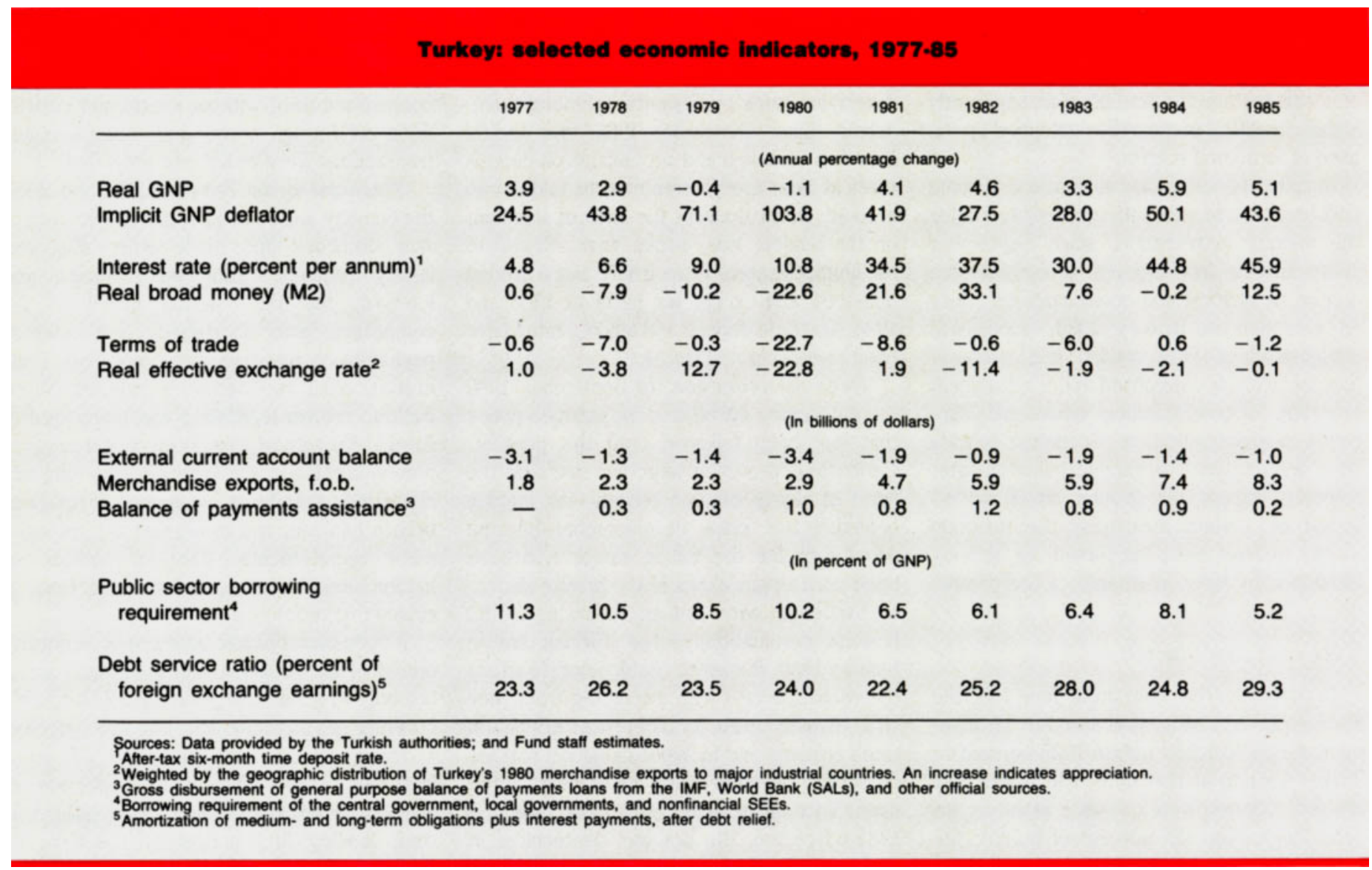

1980 and 1982, from over 5 percent to 2 percent. The financial position of SEEs also improved. Thus, the public sector borrowing requirement fell by more than 4 percent of GNP, facilitating a tight monetary policy stance. In the latter part of 1982, however, financial policies began to ease. In the wake of a financial crisis in the middle of that year-brought about largely by interest-rate deregulation in the absence of safeguards against unsound financial practices and protection of bank deposits-monetary control was eased. Encouraged by a temporary deceleration in the rate of inflation, in 1983 the authorities lowered time deposit rates significantly.

As inflation reaccelerated, from the end of 1983 onwards, on various occasions the authorities sought to reinstate monetary tightness through a more active interest rate policy, reductions in rediscount operations and increments in the legal liquidity ratio. These steps, however, were not sufficient to offset the liquidity injection associated with the improved balance of payments position, rapid accumulation of newly opened foreign exchange deposits-left outside the scope of monetary control-and ongoing financial innovations.

The main obstacle to sterilizing the liquidity buildup stemming from external sources and from financial reforms was the deterioration in public sector finances. Failure to take adequate budgetary action to compensate for the impact of tax rate cuts led the consolidated budget deficit to rebound to nearly 5 percent of GNP by 1984 . The slippage in the budget was largely corrected in 1985 , when the introduction of the value-added tax contributed to a reduction in the budget deficit to the equivalent of around 2 percent of GNP. Meanwhile, there were further gains in the profitability of nonfinancial SEE operations, with the operating surplus of enterprises rising from virtually nil in 1980 to about 4 percent of GNP in 1985, while the net inflow from the consolidated budget (i.e., transfers less direct taxes), in excess of 4 percent of GNP, turned into a small net outflow.

\section{Economic results}

Restrictive demand management led to a rapid deceleration of the inflation rate from 104 percent in 1980 to about 28 percent in 1982. Spurred by the decontrol of time deposit rates and the downturn in the rate of inflation, real broad money balances increased by two thirds between 1980 and 1982 . The revival of financial intermediation facilitated a significant recovery of fixed capital formation and output. Following a two-year contraction, real GNP growth exceeded 4 percent in both 1981 and 1982; real private fixed investment rose above 5 percent in the latter year.
Despite a marked deterioration in Turkey's terms of trade and weakening in import demand abroad, the external current account deficit was cut from $\$ 3.4$ billion in 1980 to $\$ 0.9$ billion in 1982 , as export volume more than doubled and workers' remittances and other income from services increased significantly. The foreign balance contributed almost one half of real GNP growth in 1981-82.

In 1983 there was a setback in overall performance. Real GNP growth fell by more than 1 percentage point and the external current account deficit rose to $\$ 1.9$ billion owing in part to a weather-related shortfall in agricultural production and a weakening of export prices. In addition, relaxation of financial policies contributed to an acceleration of domestic demand growth, thus exacerbating the external imbalance, while some necessary price adjustments were postponed until after the November elections.

In 1984, the delayed price adjustments in combination with a stepped-up depreciation of the lira, removal of export restrictions and sustained surge in domestic demand, resulted in an inflation rate in excess of 50 percent. Real GNP growth rebounded to nearly 6 percent partly on the strength of an exportled expansion of industrial output. With the enhanced competitiveness of the lira and the liberalization of the trade regime, the external 
current account deficit fell to $\$ 1.4$ billion. By the end of 1984, gross foreign exchange reserves of the banking system had reached an unprecedented level of $\$ 3.1$ billion, equivalent to nearly four months of imports.

In 1985-the first year without debt relief and without a stand-by arrangement with the Fund since 1978-Turkey made further progress toward adjustment. Buoyed by a continued rise in merchandise exports and a strong growth in tourism, the current account deficit was reduced further, to $\$ 1$ billion or 2 percent of GNP, while economic growth remained at 5 percent. The introduction of the value-added tax contributed to a surge in the annualized rate of inflation to close to 60 percent in the first quarter; however, by the end of the year, the rate of inflation fell below 40 percent. At end-1985, total external debt stood at $\$ 25.4$ billion (equivalent to almost one half of GNP), of which $\$ 6.6$ billion constituted short-term obligations-one half in the form of emigrants' deposits.

Overall, the Turkish recovery was underpinned by a dramatic growth and diversification of exports of goods and services (construction, transport, and tourism). Between 1980 and 1985, the share of merchandise exports in GNP had more than tripled, to an unprecedented 15 percent. Although aided to an extent by Turkey's geographical location, successful market penetration can be ascribed chiefly to the application of appropriate policies--notably, a flexible exchange rate and external liberalization. The share of Turkish exports in total exports of non-oil developing countries to industrial countries rose from less than 1 percent to near 2 percent and to Middle East partner countries from 4 percent to 20 percent during this period.
International capital markets reacted favorably to Turkey's external performance. In addition to project-related borrowing and trade credits, Turkey obtained spontaneous medium-term balance of payments support loans totaling $\$ 1$ billion over the period 1983-85 from commercial banks abroad. At the same time, however, multinational firms did not expand operations significantly in Turkey; in spite of the liberalized treatment of incoming foreign investment, their perception seemed to be that the economic environment was not yet sufficiently stable.

The least tractable aspect of the adjustment effort centers on the program's social consequences. Here, data are limited. Arguably the increase in the recorded rate of unemployment (from about 15 percent to over 16 percent) between 1980 and 1985 stemmed largely from a structural decline in agricultural employment and a marked deceleration in the growth of demand for Turkish workers abroad, rather than from economic policies. Indeed, during the program period, the annual growth in nonagricultural employment averaged almost 3 percent, notwithstanding the freeze on public sector hiring. Further, while average gross real wages are estimated-on the basis of data on a limited sample of the workforce-to have fallen more than 3 percent yearly since 1980 , the real take-home pay of workers (after taxes and transfers) is estimated to have increased yearly by about 3 percent in the private sector and by close to 5 percent in the public sector.

\section{Conclusion}

The adjustment program adopted by Turkey in $\mathbf{1 9 8 0}$ has been reasonably successful in reducing the external disequilibrium, bringing down the rate of inflation and restoring a satisfactory growth rate, despite a sharp deterioration in the terms of trade and weakening in foreign demand. This performance-when compared with a number of less successful experiences elsewhere-is attributable to the combination of three basic elements that were present in the Turkish case. First, apart from some slippages in policy implementation-in particular as regards demand management in 1983-84-the Turkish program consisted of a fairly comprehensive, consistent, and well-sequenced set of stabilization and structural measures. Second, these economic policies were implemented in a stable social and political climate that evolved shortly after the beginning of the program; moreover, with minor exceptions, the authorities were deeply committed, while the population, albeit with some reservations, tacitly endorsed the adjustment program. Third, the program was supported with external assistance by multilateral institutions, official sources, and commercial banks, in an amount broadly commensurate with the financing need and the policy effort.

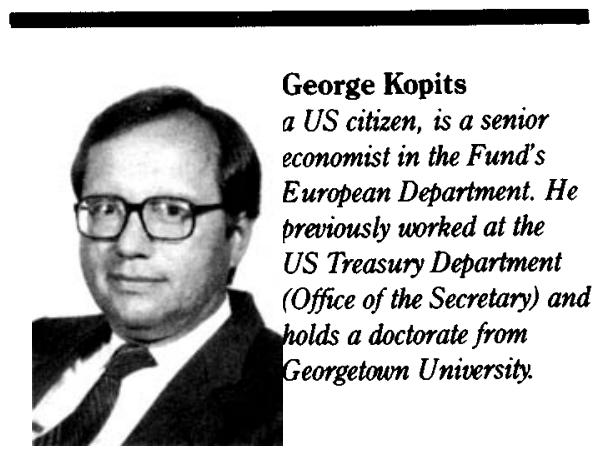

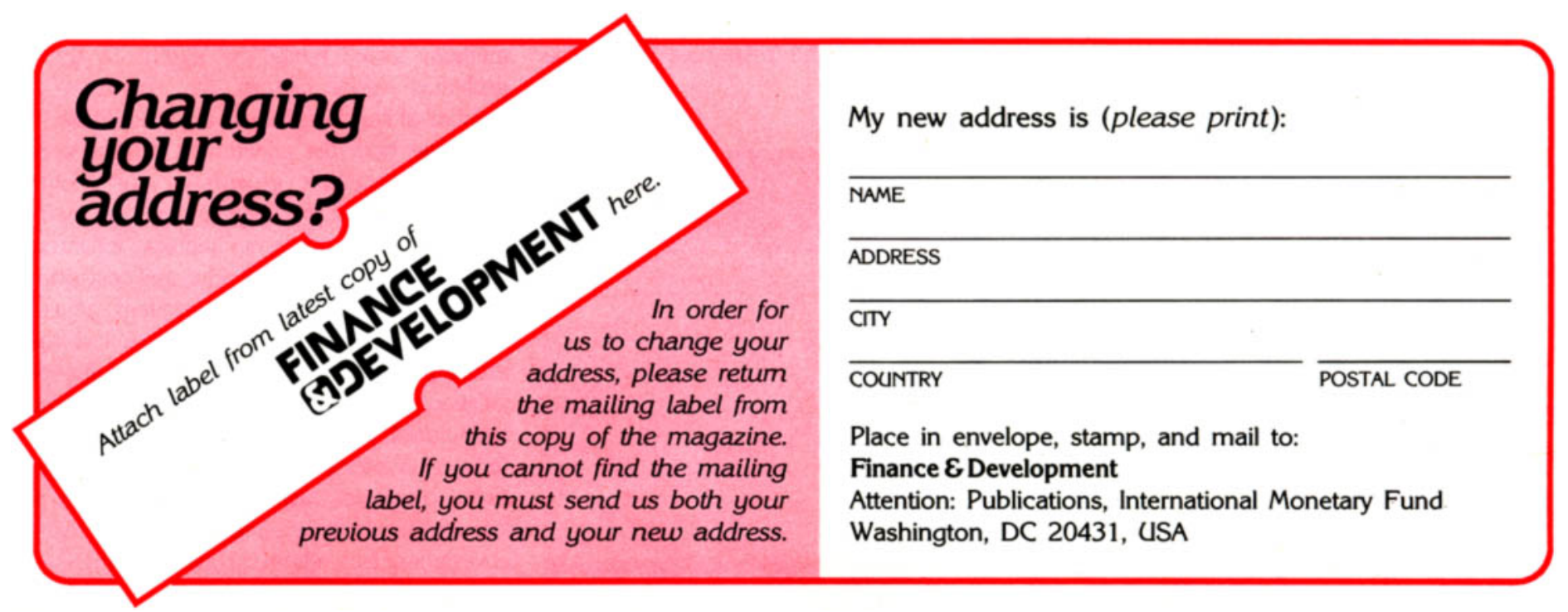




\title{
Growth and Adjustment in South Asia
}

\section{Experiences of Bangladesh, India, Pakistan, and Sri Lanka in implementing adjustment programs supported by the extended Fund facility}

\author{
Bijan B. Aghevli, In-Su Kim, and Hubert Neiss
}

D uring the late 1970 s and early $1980 \mathrm{~s}$, the international economy experienced the reemergence of serious payments imbalances, primarily reflecting the sharp increases in oil prices and the precipitous decline in commodity prices. These imbalances were particularly pronounced in the non-oil developing countries, which suffered not only from the marked deterioration in their terms of trade, but also from the ensuing recession in the industrial countries and the sharp rise in international interest rates. The severe external payments difficulties facing these countries led to a substantial increase in the number of adjustment programs supported by Fund resources under stand-by and extended arrangements, from 54 (with a total commitment of SDR 8 billion) during 1976-78, to 88 (committing SDR 24 billion) during 1979-81.

This increase in Fund-supported programs was accompanied by a growing emphasis on

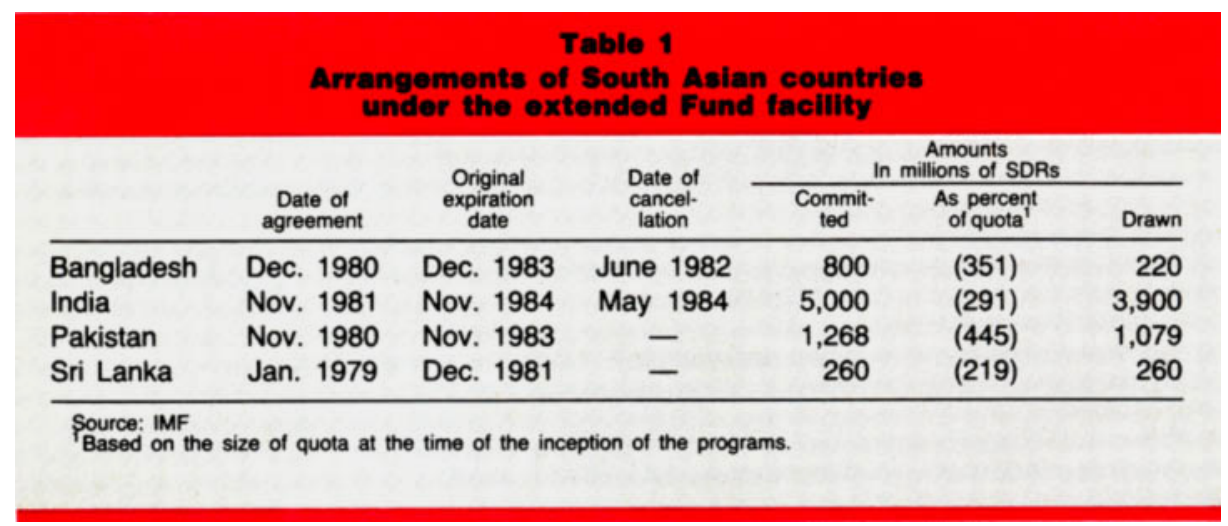

structural adjustment to strengthen productive capacity and foster growth. In view of the substantial payments imbalances and the apparent persistence of the shift in the terms of trade, the adjustment strategy generally attempted to supplement traditional demandoriented policies with more comprehensive structural polices. These policies were designed to improve resource allocation, promote domestic investment and savings, and strengthen external competitiveness. This shift in the adjustment strategy was reflected in a marked increase in member countries' recourse to extended arrangements with the Fund, which were designed to provide medium-term assistance to cope with structural imbalances. Among the members that entered into such arrangements were four South Asian countries-Bangladesh, India, Pakistan, and Sri Lanka-which together accounted for more than half of the total commitment of Fund resources under the extended facility during 1979-81 (Table 1).

This article reviews the design and implementation of the growth-oriented adjustment programs adopted by the four South Asian countries, and attempts to analyze the impact of both policy and exogenous variables on actual developments during the program periods.

\section{Background}

The four countries initiated adjustment efforts in the late 1970 s before the introduction of the extended arrangements with the Fund. Except in India, these efforts to counter a deteriorating external position were supported by regular stand-by arrangements with the Fund. However, despite the progress made in achieving economic adjustment, the four countries continued to face a number of deep-rooted structural problems that required sustained reform efforts over the medium term. While the extent of these problems varied across the countries, a number of common factors are identifiable.

At the time the adjustment efforts were launched economic growth in most South Asian countries was hampered by inefficiencies in key economic sectors, industrial and infrastructure bottlenecks, and cost-price distortions arising from infrequent adjustments of both administered prices and the exchange rate in the face of domestic inflation. Further, adverse weather disrupted agricultural production and, in the case of India, also interfered with power generation. Fiscal conditions remained weak because of low and inelastic revenue and rapidly rising government expenditure propelled by increas- 
ing social and development needs. The fiscal imbalance was a primary reason for excessive monetary expansion, and consequent inflationary pressures.

Meanwhile, weak production bases, together with inadequate producer incentives, continued to constrain the countries' export capacities. At the same time, rising domestic demand led to strong import demand, which was suppressed through tight exchange and import controls at the expense of economic efficiency. These strains on the domestic economies and the balance of payments positions were intensified by the marked deterioration in the terms of trade and the subsequent slowdown in export markets.

\section{Design of extended programs}

The adjustment strategy adopted by the countries under review was to strengthen productive capacity and promote economic expansion in a climate of financial and external stability. Higher economic growth rates were to be realized by supply-side measures designed to raise both domestic investment and savings and to improve the efficiency of production and resource allocation. The latter goals were to be achieved primarily by correcting cost-price distortions, relaxing restrictive industrial regulations, and liberalizing trade policies. All these policies were to be accompanied by restrained financial management aimed at maintaining price stability in order to facilitate structural adjustment. In view of the relatively long gestation period of structural programs, the external current account position was expected to improve only gradually.

Underlying the supply-oriented adjustment strategy was the recognition that there was substantial scope for export growth and import substitution in these economies through the removal of structural imbalances and bottlenecks. The strategy was also consonant with the urgent developmental need to provide employment for the growing labor forces and to alleviate poverty. The adjustment programs were, to varying degrees, incorporated into national development plans.

The adjustment programs of all four countries envisaged a substantial increase in domestic investment. In view of the major role of the public sector in these countries, the government was expected to take the lead in expanding investment. In general, public sector investment programs were to be reviewed and reoriented in close consultation with the World Bank to improve infrastructure, exploit comparative advantage, and avoid projects with excessively long gestation periods. Most programs foresaw a broadened role for private investment, encouraged by the adoption of policies conducive to liberal industrial and import licensing arrangements and to foreign collaboration.

The increase in domestic investment was to be financed by greater domestic resource mobilization, mainly through the public sector. The government budget was expected to generate larger savings through tax reforms, reductions in subsidies, and restraint in wage outlays. Substantial savings were also to be generated by nonfinancial public enterprises primarily through flexible pricing policies and the rationalization of their operations. The programs also generally stressed the need for encouraging private savings through flexible interest rate policies, introduction of new financial instruments, and strengthening of financial intermediation.

The alleviation of cost-price distortions was seen to be essential for improving resource allocation and stimulating production. Procurement prices were to be increased substantially, particularly for those agricultural commodities that were either exportable or import substitutes. Administered prices for industrial outputs were also to be adjusted more flexibly to reduce distortions. Furthermore, increased financial incentives were designed to improve the profitability and external competitiveness of the export sector, which had been adversely affected by heavy indirect taxes and inflationary pressures. A flexible exchange rate policy responding to developments in domestic and external prices would support these measures.

A crucial element of the adjustment programs was the liberalization of restrictive industrial and import regulations which had been pervasive. In order to encourage private sector production and facilitate modernization, the programs called for the simplification of licensing approval procedures and for the easing of regulatory restraints on capacity utilization and expansion, particularly in India. The liberalization of imports was aimed primarily at ensuring increased access to raw materials and intermediate goods so as to alleviate supply bottlenecks and improve international competitiveness. Imports of capital goods were also to be liberalized in order to improve the efficiency of domestic production and investment. The program in Pakistan envisaged a shift from quantitative restrictions to tariffs for regulating imports and protecting domestic industry.

Notwithstanding the emphasis on structural measures, prudent demand management remained a principal element of the adjustment programs, as financial and price stability was viewed as a fundamental prerequisite for successful economic adjustment. A major policy objective was the strengthening of the budgetary position through measures to increase revenue and restrain expenditure. The programs sought to reduce substantially the overall budget deficit and thus government recourse to bank borrowing. At the same time, they envisaged restraints on the growth of liquidity and domestic credit to moderate inflationary pressures while supporting economic growth and private sector activity.

\section{Performance under programs}

The performance of the four economies with respect to growth, inflation, and external adjustment was uneven: India and Pakistan broadly achieved the original objectives of the programs, while Sri Lanka and Bangladesh were less successful in meeting all their targets. Generally, the average economic growth during the program period was broadly in line with program targets (Table 2). In the case of India and Pakistan, a favorable growth outcome was accompanied by relative financial and price stability and a larger-than-anticipated improvement in the external current account deficit. In contrast, Sri Lanka suffered from both intensified inflation and a marked deterioration in its current account balance. In the case of Bangladesh, program objectives in terms of both growth and inflation were not met and the reduction in the current account deficit was made possible only through a drastic cut in the issuance of import licenses. The Fund's extended arrangement with Bangladesh became inoperative during its first year.

The path and pace of adjustment in these economies were influenced significantly by unanticipated developments in exogenous factors and policies. Droughts during the programs adversely affected growth in Bangladesh, India, and Sri Lanka. The task of adjustment was further complicated by the prolonged international recession and by a precipitous decline in export prices that reinforced emerging fiscal difficulties, especially in Bangladesh and Sri Lanka. On the other hand, all four countries benefited from higher-than-expected remittances particularly from oil exporting countries, and from only moderate increases in oil prices (which were especially important for India).

The extent of policy implementation also varied across the four programs. On the whole, significant progress was made in the area of pricing policy: incentives to agricultural producers were raised, subsidies were reduced, and the financial position of public enterprises was improved. The price adjustments, however, did not eliminate certain costly subsidies or mobilize sufficient resources for investment in some cases. However, implementation of structural measures, especially those aimed at increasing 


\begin{tabular}{|c|c|c|c|c|}
\hline \multicolumn{5}{|c|}{$\begin{array}{c}\text { Table } 2 \\
\text { Selected economic indicators of four } \\
\text { (In percent) }\end{array}$} \\
\hline & \multirow[b]{2}{*}{ Pre-program } & \multicolumn{2}{|c|}{$\begin{array}{c}\text { Program annual } \\
\text { average }\end{array}$} & \multirow{2}{*}{$\begin{array}{c}\text { Post-program } \\
\text { annual average }\end{array}$} \\
\hline & & Targets & Outcome & \\
\hline \multicolumn{5}{|l|}{ Bangladesh } \\
\hline Reál GDP growth & 3.5 & 7.2 & 3.7 & 3.1 \\
\hline Inflation (Consumer Price Index) & 18.5 & 11.5 & 14.4 & 10.2 \\
\hline \multicolumn{5}{|l|}{ External current account as } \\
\hline proportion of GDP & -11.5 & -12.09 & -10.6 & -8.1 \\
\hline Exports (In billions of dollars) & 2.4 & 0.9 & 0.7 & 0.8 \\
\hline Imports (In billions of dollars) & 2.4 & 2.8 & 2.5 & 2.4 \\
\hline \multicolumn{5}{|l|}{ India } \\
\hline Real GDP growth & 7.8 & 4.8 & 5.3 & 4.0 \\
\hline Inflation (Wholesale Price Index) & 18.2 & 9.3 & 6.1 & 6.4 \\
\hline External current account as & & & & \\
\hline proportion of GDP & -1.6 & -2.1 & -1.6 & -1.4 \\
\hline Exports (In billions of SDRs) & 6.6 & 9.5 & 7.6 & 8.6 \\
\hline Imports (In billions of SDRs) & 12.3 & 15.4 & 13.2 & 13.3 \\
\hline \multicolumn{5}{|l|}{ Pakistan } \\
\hline Real GDP growth & 7.3 & 5.7 & 6.5 & 5.3 \\
\hline Inflation (Consumer Price Index) & 10.7 & 10.0 & 8.4 & 8.0 \\
\hline External current account as & & & & \\
\hline proportion of GDP & -4.5 & -4.6 & -3.3 & -4.2 \\
\hline Exports (In billions of dollars) & 2.4 & 3.2 & 2.6 & 2.5 \\
\hline Imports (In billions of dollars) & 4.9 & 6.2 & 5.6 & 6.0 \\
\hline \multicolumn{5}{|l|}{ Sri Lanka } \\
\hline Real GDP growth & 5.8 & 6.0 & 6.0 & 5.1 \\
\hline Inflation (GDP deflator) & 7.8 & 11.7 & 18.1 & 15.1 \\
\hline External current account as & & & & \\
\hline proportion of GDP & -5.5 & -10.8 & -14.9 & -10.4 \\
\hline Exports (In billions of SDRs) & 0.7 & 0.9 & 0.8 & 1.1 \\
\hline Imports (In billions of SDRs) & 0.8 & 1.2 & 1.4 & 1.8 \\
\hline \multicolumn{5}{|c|}{$\begin{array}{l}\text { Source: IMF } \\
\text { Note: dates for pre-program, program, and post-progam periods are defined as follows: }\end{array}$} \\
\hline $\begin{array}{l}\text { Pre.Program } \\
\text { period }\end{array}$ & \multicolumn{2}{|c|}{$\begin{array}{c}\text { Program } \\
\text { period }\end{array}$} & \multicolumn{2}{|c|}{$\begin{array}{l}\text { Post-program } \\
\text { period }\end{array}$} \\
\hline $\begin{array}{l}\text { India } \\
\text { Pakistan } \\
\text { Sri Lanka } \\
\text { Bangladesh } \\
\text { 'Partly preliminary. }\end{array}$ & \multicolumn{2}{|c|}{$\begin{array}{l}1981 / 82-1983 / 84 \\
1980 / 81-1982 / 83 \\
1979-1981 \\
1980 / 81-1981 / 82\end{array}$} & \multicolumn{2}{|c|}{$\begin{array}{l}1984 / 85-1985 / 86 \\
1983 / 84-1984 / 85 \\
1982-1984 \\
1982 / 83-1984 / 85\end{array}$} \\
\hline
\end{tabular}

tax revenue, mobilizing private savings, and relaxing industrial and import controls, was weaker than envisaged. Measures taken to promote exports were also modest. Financial policies were generally restrained in India and Pakistan, but they turned out to be expansionary in Bangladesh and Sri Lanka.

Production, investment, and prices. The favorable growth performance achieved by India, Pakistan, and Sri Lanka was generally associated with higher agricultural production. This reflected the effects of policies to increase the area under irrigation and to stimulate the spread of modern production techniques and inputs, particularly fertilizer; the use of fertilizer was encouraged by reducing its price and by strengthening support services to farmers (India and Paki- to a substantial reduction in oil imports in the former.

Domestic investment relative to GDP was below target in both India and Pakistan. Public investment in these countries was lower than expected because of limited resource mobilization by the public sector. In India, private investment was constrained by weak domestic and external demand in the aftermath of the oil price increases and by uncertainties over the relaxation of industrial regulations and import controls. Sri Lanka was successful in achieving the program growth target, but at the expense of excessive expansion of public sector investment; private investment in the country also remained buoyant, aided by monetary and fiscal concessions and low prices for imported capital goods.

Despite the importance attached to domestic resource mobilization, savings fell short of program targets in all four countries. Shortfalls were registered by both the public and private sectors in the case of India. In India and Sri Lanka, private savings were adversely affected by drought-induced declines in agricultural income, a sharp fall in the terms of trade, higher energy prices, and weak policy initiatives. Weaker than expected domestic resource mobilization, however, was partly offset by buoyant workers' remittances in most South Asian countries.

Inflation subsided broadly in line with program targets in India and Pakistan, as restrained financial policies and improved supplies more than offset the increases in administered prices. In Sri Lanka, however, the rapid expansion in domestic credit, combined with a sharp increase in international oil prices, gave rise to strong inflationary pressures, and the program targets were exceeded by a wide margin. Inflationary pressures were also strong in Bangladesh.

External developments. The cumulative current account deficit in India and Pakistan over the program period was substantially smaller than targeted. Bangladesh also kept its current account deficit below target, primarily through a substantial tightening of import licensing. In contrast, the current account deficit in Sri Lanka exceeded the program target because of higher imports and poor export performance.

Stronger net exports of services (workers) and private transfers (remittances) helped limit the deficits in India and Pakistan. In the former, a significant decline in imports, mainly because of reduced oil imports, also contributed to the lower deficit. The growth of non-oil imports was generally slower than expected in these countries, largely because of the improved domestic availability of key agricultural commodities and industrial inputs.

Exports were considerably below expecta- 
tions in all four countries. The cumulative shortfall in export earnings largely offset the gains achieved in lowering imports in India and Pakistan. In most countries, the average growth rate of export volume was below that achieved by non-oil developing countries during the corresponding period. The disappointing export growth performance reflected the severe international recession, lingering domestic impediments to export development, and generally weak external competitiveness.

\section{Post-program developments}

During the program period, the South Asian countries stepped up their efforts at structural adjustment. The progress made in this area, however, was relatively limited, partly because of the intensity of structural imbalances before the programs, but also because of delays in policy implementation and the lags before policies become effective. In order to sustain the structural adjustment efforts, most countries introduced follow-up measures after the Fund-supported structural adjustment program came to an end.

In India, significant liberalization measures were taken during 1985 in the areas of industrial licensing, import policy, and tax and financial reforms. The coverage of antimonopoly legislation was reduced considerably through a substantial increase in the asset limit and the exemption of a large number of industrial groups from restrictions on capacity expansion. In addition, most of the exempted industries were no longer required to operate under licenses and large companies were permitted to diversify their operations. Regulations applying to foreign collaboration and investment were liberalized with a view to facilitating import of technology. Substantial progress was made toward a more liberal import regime through the removal of licensing requirements, simplification of procedures, and the termination of monopoly imports by public corporations for a wide range of materials and components. In the area of tax policy, the structure of direct tax was rationalized, with a substantial reduction in tax rates and an increase in the exemption limit for personal income tax, in order to foster private sector growth and reduce tax evasion. Steps were also taken to alleviate rigidities in the interest rate structure through an increase in interest rates on government securities. Complementary action is now under consideration for further financial sector reform.

In Bangladesh, an adjustment program was reinstated in 1982/83 and supported by a new stand-by arrangement. Under the new program, the fiscal position was improved by increasing taxes, reducing subsidies, and adjusting key administered prices. At the same time, exchange rate policy was conducted more flexibly and a more liberal import policy was pursued with a view to improving the efficiency of the economy, especially that of the export sector. Adjustment efforts were stepped up in 1985/86 supported by another stand-by arrangement, in order to deal with a re-emerging deterioration in the balance of payments and weakening in growth performance.

The authorities in Pakistan continued to pursue flexible pricing policies for petroleum and gas, leading to a significant increase in petroleum production and to the containment of petroleum subsidies. However, further progress toward structural adjustment was needed in key areas, including tax reform, liberalization of import controls, and promotion of manufactured exports.

The pace of structural adjustment in Sri Lanka was slowed by the deterioration in national security, while the need for urgent action was softened by a marked boom in export prices of key primary commodities in 1983/84. The authorities, however, have

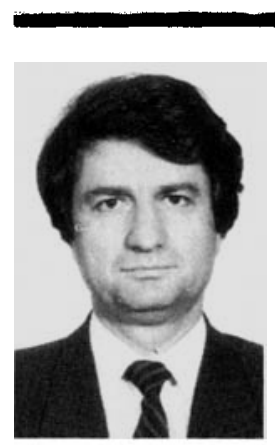

Bijan B. Aghevli from Iran, is Assistant Director in the Asian Department of the Fund. He holds a $P h D$ in Economics from Brown University and taught at the London School of Economics before joining the Fund staff.

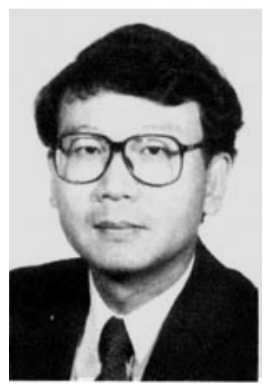

In-Su Kim from the Republic of Korea, is an Economist working on India in the Asian Department of the Fund.

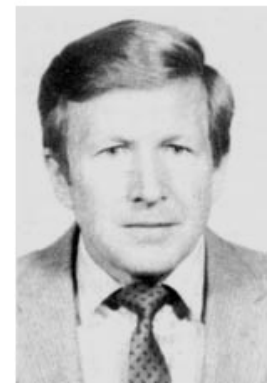

Hubert Neiss from Austria, worked at the Austrian Institute for Economic Research in Vienna before joining the Fund staff in 1967; he is Deputy Director in the Asian Department. been cognizant of the need to overcome the long-standing structural weaknesses in the economy, especially the diminishing growth potential of the narrowly based export sector, a weak budgetary process, and the poor performance of public enterprises. The first step in a phased program of tariff reform was undertaken in late 1984.

Notwithstanding the further steps some of them have taken, continued adjustment efforts remain essential in the South Asian countries, particularly in the areas of export development, economic efficiency, and public finance. During the post-program period, export volume growth has remained generally low, partly reflecting slow improvement in economic efficiency. With the exception of Sri Lanka, the fiscal deficit has widened, as expenditure has risen rapidly in the face of stagnant revenues; in the case of Sri Lanka, a large cutback in current expenditure resulted in a substantial decline in the fiscal deficit. The weak management of public enterprises has remained a source of low productivity and financial instability in most countries.

\section{Conclusions}

The adjustment strategy of Fund-supported programs underwent a major shift in the late 1970 s in response to the change in economic environment arising from the sharp rise in oil prices and the associated imbalances in members' payments positions. Adjustment programs placed greater emphasis on structural measures to promote domestic resource mobilization, alleviate price distortions, ensure increased access to imports, and reorder investment priorities in countries that sought Fund assistance.

The adjustment programs adopted by the four South Asian countries, which have much in common in the way of economic legacy and structures, were framed against this emerging shift in the Fund's adjustment strategy. Under the programs, these countries were generally successful in achieving their growth objectives, despite a deepening of the international recession and adverse weather conditions. Notwithstanding this growth performance, the extent of structural adjustment achieved in key areas was below expectations. Public sector resource mobilization was constrained by inadequate returns from improvements in the tax systems and by rising current expenditure.

The most disappointing development for all four countries was the continued weakness in export performance. Export growth was below that achieved by other developing countries, mainly because of low productivity growth and inadequate financial incentives. Despite some progress in liberalizing trade 
regimes, the continuing tight control on imports constrained improvements in economic efficiency and export growth. Although there appears to be further scope for external adjustment through efficient import substitution in these countries, the strong development of the export sector is crucial for achieving external viability over the medium term. In these circumstances, continued progress in liberalizing industrial and import controls and in improving the profitability and external competitiveness of the export sector remains essential.

The experience of the South Asian countries during the program periods confirms that restrained financial management plays a major role not only in improving the balance of payments but also in facilitating structural adjustment. The cases of Bangladesh and Sri Lanka demonstrate that, in the absence of financial stability, it is difficult for the authorities to focus their attention on structural adjustment. In addition, financial instability tends to exacerbate existing cost-price distortions, resulting in inappropriate investment patterns and inadequate savings. In view of the dominant role of fiscal operations, success in demand management will inevitably require bold actions to reform the tax systems and limit the excessive expansion in current expenditure.

The slower-than-expected progress in undertaking structural adjustment was primarily attributable to delays in policy implementation. These delays were associated both with long and careful preparations required for most of the structural measures and with weaknesses in administrative capacity for effective policy implementation. These technical and administrative constraints were compounded by social and political resistance to structural reforms. In view of the lengthy process of forming a political consensus for reform, the required measures were implemented only gradually in these countries.

In conclusion, our review of the structural adjustment experiences of Bangladesh, India, Pakistan, and Sri Lanka suggests that successful reforms require considerable preparation so that they can be implemented swiftly when the conditions are ripe. Further structural adjustment can only be successful if the momentum of economic reforms that are initiated under a Fund-supported program is sustained beyond the period of the program. Ultimately, it is the commitment of governments to reforms that determines the pace and intensity of structural adjustment. It is, therefore, encouraging that in all four countries structural efforts have been continued and, in some areas, intensified following the Fund-supported adjustment programs.

\section{Trade Liberalization in Chile}

\author{
How one Latin American economy \\ undertook far-reaching reforms
}

\begin{abstract}
$\mathbf{F}$ F or decades many of the Latin American economies suffered large fiscal deficits, balance of payments problems, runaway inflation, and distorted financial systems. The depression of the 1930s and the enforced self-reliance of World War II gave an impetus to import substitution. This became the region's dominant industrial strategy in the 1950s.

Several limited experiments in stabilization and liberalization were carried out in the 1960s, notably in Brazil and Chile from 1964 and in Colombia from 1967. These countries adopted more realistic exchange rate policies-partly through domestic stabilization effortsand tried to reduce the bias against manufactured exports. They made less progress, however, in reducing import protection. Brazil and Colombia-whose reforms were more extensive than Chile's--saw much improved export performance.
\end{abstract}

\section{Southern Cone experiments}

The most significant experiments in trade liberalization in the 1970s took place in the countries of the Southern Cone of Latin America: Argentina, Chile, and Uruguay. These countries tried to stabilize and liberalize their highly controlled economies against an international background of recession, inflation, declining terms of trade, and the

This text and charts are based on World Development Report 1987. The Chilean experience has also been the subject of a recent book by Sebastian Edwards and Alexandra Cox Edwards, reviewed in this issue by Claudio Loser. 
volatile capital flows which helped to provoke the international debt crisis of the 1980s. New governments came to power in the mid-1970s in all three countries and designed farreaching liberalization programs. These radical reforms were undertaken in the face of entrenched political opposition to economic reform, which had grown out of the failure of several earlier attempts.

All three countries carried out an initial stabilization program of reduced public expenditure and devaluation, together with a program of economic liberalization measures which included removing quantitative restrictions, cutting the highest tariffs, reducing price controls, and reforming the financial system. But important differences in the emphasis and sequencing of policies in the three countries contributed to different outcomes for the three experiments. Chile attached great importance to a radical reform of trade policy, and this reform was achieved before the liberalization of capital account transactions. Argentina and Uruguay liberalized the capital account comparatively early and made less progress in reducing pro- tection. In the early 1980 s all three countries faced severe economic crises that were the result partly of international conditions but largely of their own mistakes, particularly in pursuing policies that encouraged a real appreciation of the exchange rate. Chile, whose trade reforms survived the crisis, and Argentina, whose reforms did not, provide an instructive contrast.

\section{Trade reforms}

Chile's trade liberalization was unprecedented for its speed and breadth. Trade

\section{Chart 1 \\ Major economic Ilberalization policies in Chile, 1972-86}

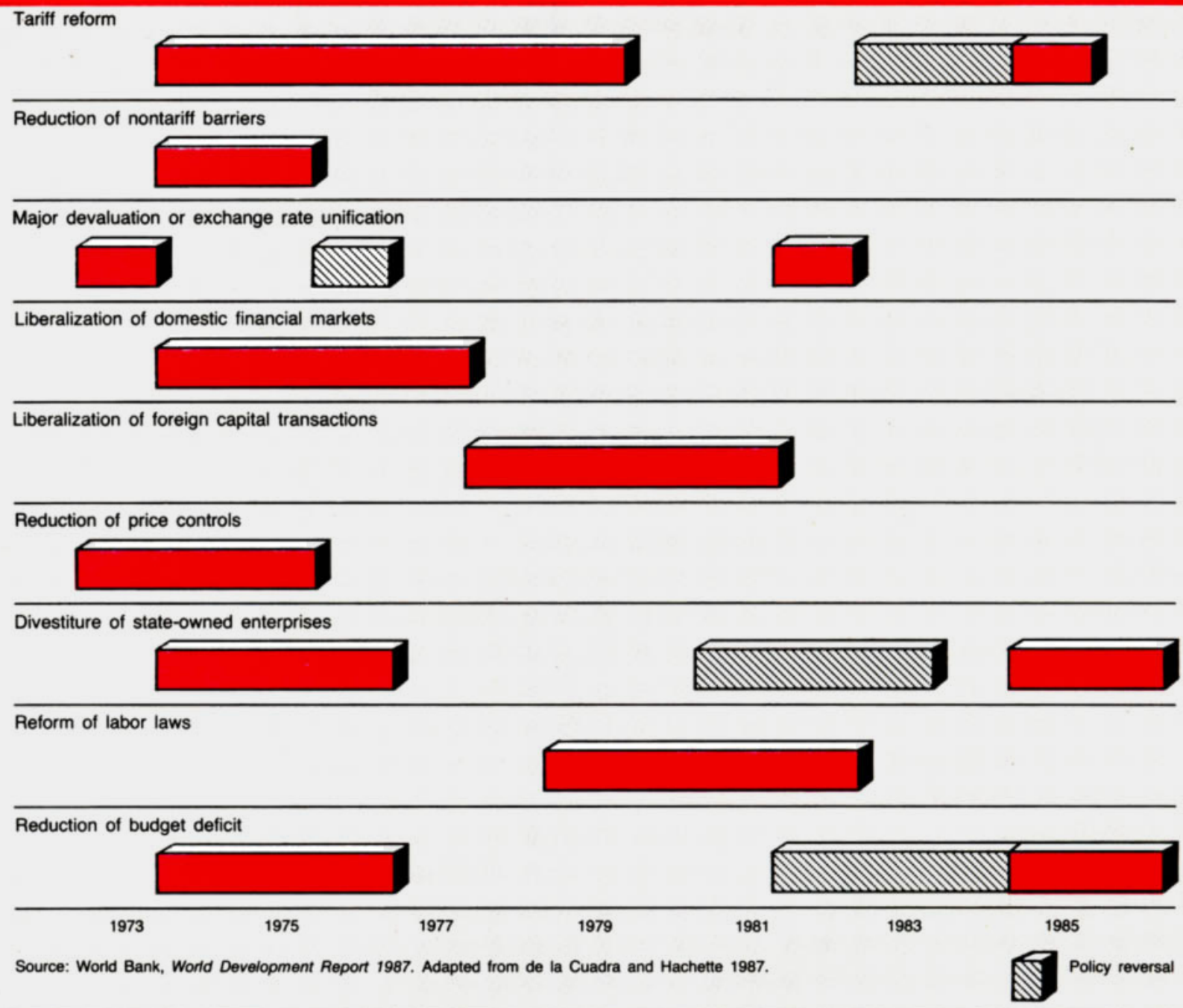


reforms followed in the immediate wake of other major reforms (see Chart 1). These included the virtual elimination of a large budget deficit (starting in 1974); the elimina- tion of multiple exchange rates (1973-76); a large real devaluation (in 1973), followed by the adoption of a crawling peg exchange rate; the removal of price controls (from 1973);
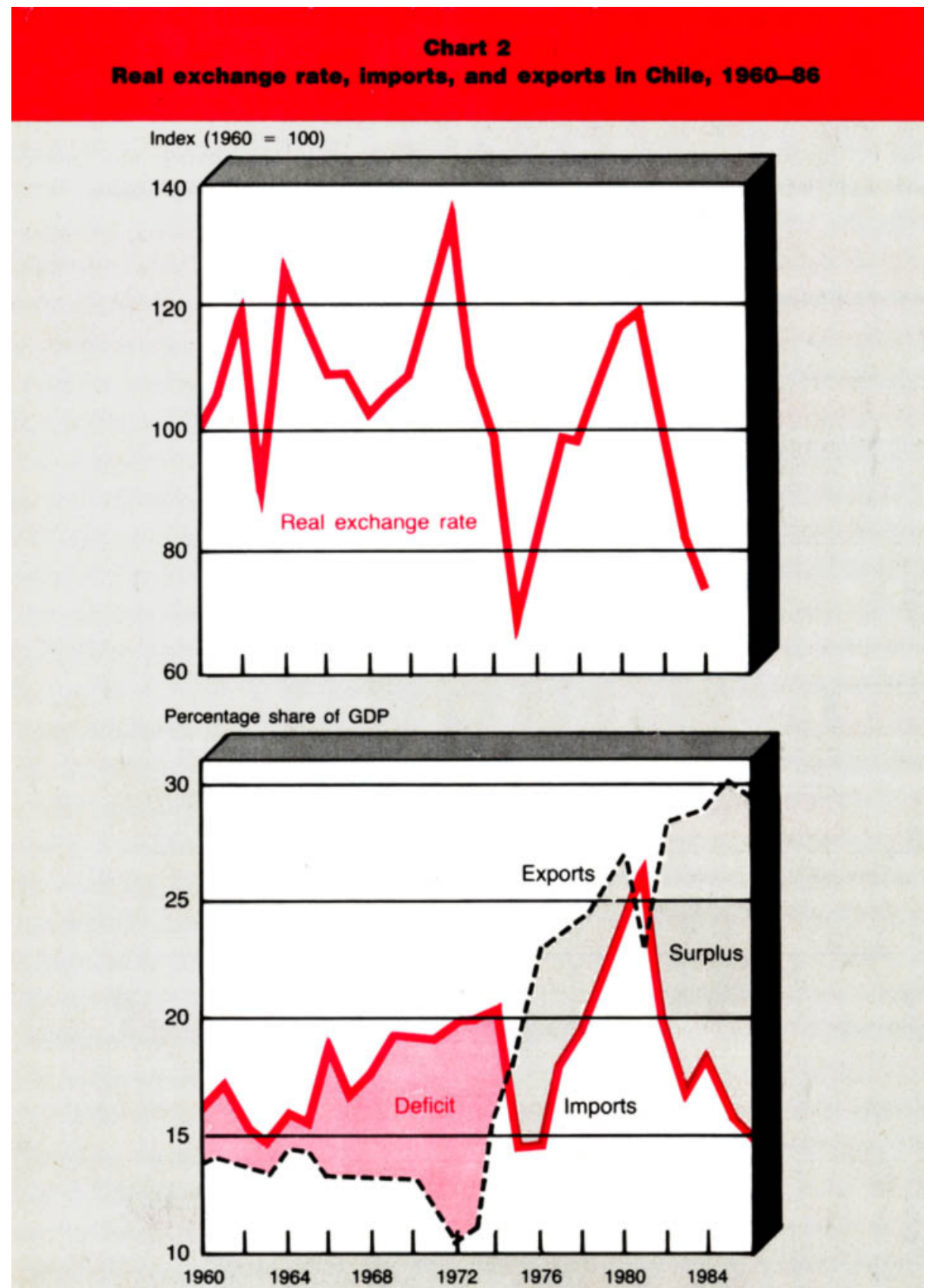

Source: World Bank, World Development Report 1987.

Note: A rise in the index of the real exchange rate indicates an appreciation, and a fall indicates a depreciation.

divestiture of public enterprises (from 1974); and liberalization of domestic financial markets (from 1974). In 1974-75 the government removed quantitative restrictions on imports. It had already started to introduce a series of progressively more liberal tariff reforms, and by 1979 it had achieved a uniform tariff of 10 percent. Exports were neither taxed nor subsidized (although an import duty without a corresponding export subsidy is equivalent to a tax on exports).

Inflation, although much reduced, still persisted after the stabilization, and the government began in 1976 to use the exchange rate in its fight against inflation. Its use of the exchange rate became more systematic from 1978 on when it adopted a crawling peg exchange rate that entailed a series of pre-announced nominal devaluations at less than the differential between domestic and international rates of inflation. This system, intended to fight inflation expectations, in fact contributed, with the continued indexation of wages and the lifting of controls on capital inflows, to a gradual appreciation of the real exchange rate. This eroded much of the substantial real depreciation that had occurred since 1973 (see Chart 2). Nonetheless, the real exchange rate in the years following 1974 was on average far more favorable to the production of tradables than that for the decade preceding 1973.

After a recession in 1975-the result of stabilization measures adopted since 1973 and an adverse movement in the terms of trade from 1974-the economy responded clearly to liberalization. From 1976 to 1981 , GDP grew by 8 percent a year. Trade grew even faster-exports after 1973 and imports after 1976-until the beginning of the 1980 s, by which time the effects of the real appreciation of the peso were being felt in earnest. In the 1970s Chile began to send new products abroad-for example, fruits, vegetables, and forestry products. Its share in world exports grew, although this was also helped by favorable international markets for its nontraditional products until the beginning of the 1980s.

Chile's unemployment rate increased to 10 percent in 1974. The 1975 recession helped make the rate higher, and it remained high (between 13 and 17 percent) for the rest of the decade. Effective import barriers came 
down significantly only after 1976 . According to one estimate, trade liberalization in isolation did not lead to net job displacement: lower import protection cut employment in manufacturing, but this was offset by employment gains caused by trade liberalization elsewhere in the economy, particularly agriculture. Jobs were lost as firms went out of business or were taken over; other firms survived by achieving large gains in productivity. This rationalization was achieved with little additional investment.
An exchange rate policy that led to real appreciation, post-1977 measures to liberalize exchange controls, and high domestic interest rates all contributed to heavy borrowing from abroad. The peso's appreciation was particularly marked from 1979 to 1981 . Exports became uncompetitive, and the trade deficit soared. By late 1981 a domestic recession was setting in, and in 1982 the peso was substantially devalued. The recession was so deep that unemployment reached 25 percent (in June 1982), and the financial sector was virtually bankrupted. The uniform import tariff was raised to 35 percent in 1984 , but came down to 20 percent in 1985 . Thus trade reform survived the crisis, and the rationalization it had fostered left Chile's industrial sector in a far stronger position to withstand the shocks of the 1980 s. In recent years the economy has grown strongly, and unemployment has come down to under 10 percent. Economic liberalization clearly contributed to this recovery.

\section{Can governments ease the trade reform process?}

Governments are seldom able to bring about economic reform at the stroke of a pen. They first have to overcome the opposition of groups which fear they may be adversely affected.

\section{Transparency and persuasion}

There is sometimes a bias in government decisionmaking: pressure groups can noisily voice their narrow interests, but when benefits are spread widely across the community no single group sees that it has much to gain. For example, it is easier to grasp the costs of closing down an inefficient car manufacturing plant than to see the benefits of cheaper cars and employment opportunities spread across the rest of the economy.

Another bias can arise when governments, to accommodate tensions between a sectional interest and the public interest, pass laws so vague that they appear to satisfy both. The law must then be implemented by administrative decision, and the special interest groups will attempt to influence the relevant administrators.

One way to promote public understanding of the public interest is to set up a "transparency" agency whose job would be to provide an overview of government intervention. The aim would be to help the government and the public see sectoral proposals in an economy-wide framework. Tariff commissions, established in such countries as Australia, Canada, New Zealand, the Philippines, Sri Lanka, and the United States, are intended to carry out this role, but the results have been mixed. The commissions have often spent much of their time working on highly technical questions such as whether an industry has suffered "damage" or "injury," whether it can be attributed to imports, and whether these imports are unfair in some sense.

Transparency agencies can, in fact, claim some real successes, but the problems they face should not be underestimated. On top of the sheer difficulty of predicting the future, governments are always under pressure to mute their role by diluting their terms of reference.

A possible defense against this kind of pressure would be to make full review a legislative requirement. With sufficient independence and investigative powers a transparency agency could influence other branches of the bureaucracy. A bipartisan agreement that such review would be mandatory could serve as a kind of legislative constraint on government.

\section{Safeguards and compensation}

A government trying to convince the public that a certain reform will proceed smoothly might tip the scales by offering guarantees against disruption. These might include strengthened antidumping provisions (a safeguard measure) or additional income support for those who stand to lose (a compensation measure).

Unfortunately, the experience with safeguard measures is not encouraging. In practice, the search for safeguards has become a complicated process which is carried along by its own momentum and has precious little to do with economic efficiency. For example, a recent antidumping case in Australia dealt with cherries in brine from Italy. It turned on the appropriate valuation to be attached to the drums in which these cherries were packed for shipment. It seems that "dumping" could be "proved" if the drums were valued at their price when new--but if, as turned out to be the case, some drums were secondhand, then dumping could be not proved.

Compensation measures are an alternative approach, but they too have had many defects. The costs of identifying winners and losers are very large. This is because of the practical difficulties of sorting out policy changes and their impacts-people win and lose for all sorts of economic reasons, and it is seldom possible to be sure of the cost inflicted on a particular group by any given policy. Compensation measures also create "moral hazard," in which people are given incentives to behave inefficiently to qualify for compensation.

Buying off pressure groups differs from straightforward compensation-at least in principle. It is a way of overcoming obstacles to change in an overtly political way. Even with this more limited objective, however, the record is discouraging. Far from softening resistance to change, this approach merely channels protest into pressure on governments about who should get the most compensation. 


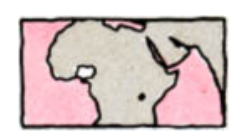

\title{
Structural Adjustment in Nigeria
}

\author{
The core of the program is being implemented. The challenge is to implement the remaining \\ part and to maintain the momentum of reform
}

\author{
Nils Borje Tallroth
}

$T$ he sharp increases in oil revenues in 1973-74 and again in 1979-80 had a pervasive effect on the Nigerian economy. These revenues provided the basis for large increases in public expenditure designed to expand infrastructure and non-oil productive capacity, even as they served the political and social purpose of healing the wounds of the civil war (1967-70). There were also substantial increases in public spending on health, education, and other social services throughout the country.

But notwithstanding some important successes, many public investment projects were undertaken without sufficient attention either to their economic viability or to the capacity of government agencies and public enterprises to implement them. Furthermore, the rapid expansion of construction and urban services that was associated with the increase in public expenditure was accompanied by price and wage increases that severely reduced producer incentives in the non-oil tradeable sectors. Agricultural exports were particularly hard hit, since the exchange rate was allowed to appreciate substantially in order to cheapen costs of imports and to curb inflation. Within a decade, Nigeria became a major food importer, while production of export crops declined substantially, making the country dependent on a volatile international oil market for almost all of its export earnings and most of its federal and state government revenues. In industry, negative real interest rates and rapid wage increases, together with the appreciating exchange rate and the system of tariff protection and import licensing, stimulated the use of imported capital-intensive technology and rapid expansion of consumer goods and assembly-type industries based on imported inputs.

During most of the $1970 \mathrm{~s}$, budgetary expenditures exceeded the rapidly rising revenues from oil. Indeed, official data show only a modest surplus even in 1980 , despite the spectacular rise in oil earnings that year. When the oil market weakened in the early 1980s-reducing Nigeria's oil export earnings from $\$ 23.4$ billion in 1980 to $\$ 9.9$ billion in 1983-the Government responded slowly. Large external and internal deficits resulted. Foreign exchange reserves were run down even as $\$ 6-7$ billion of external payment arrears were amassed. Heavy external borrowing from the late 1970 s increased outstanding medium- and long-term public debt from less than $\$ 1$ billion in 1978 to about $\$ 12.8$ billion in 1983 .

In addressing the crisis, the Government resorted to economic austerity, relying heavily on administrative controls and regulations. These reinforced rather than corrected the structural distortions that had been built up earlier. Large across-the-board cuts were made in investment expenditure, leaving projects without sufficient funding for their completion. Current expenditure was also cut but, since the wage bill was protected, falling revenues left insufficient funds for materials, supplies, and maintenance. While the austerity measures brought about a rapid decrease in fiscal and external deficits, they also brought on a serious recession. The downturn was aggravated by drought-induced declines in agricultural production in 1983 and 1984. Severe supply shortages of both imported goods and foodstuffs sharply boosted prices. Together with an inflexible nominal exchange rate policy, this resulted in an appreciation of the exchange rate in real effective terms of more than 80 percent over the period $1980-84$.

Policies changed when the new military government came to power in 1985 , declaring its intention to move from "austerity alone to austerity with adjustment" and to seek international financial support for its program. Initial reforms, including substantial increases in domestic petroleum prices, were announced in the 1986 budget. The dramatic fall in world oil prices in early 1986 increased the urgency of reform. An ambitious structural adjustment program was adopted in June 1986. The program is supported by a debt rescheduling and external financing package to provide new funds, involving commercial banks, and the Paris Club and other creditors. The World Bank is supporting the program with a Trade Policy and Export Development Loan in the amount of $\$ 452$ million. The IMF approved in January 1987 a stand-by arrangement of SDR 650 million (about $\$ 830$ million) in support of the adjustment program, though the Government has declared its intention not to draw on the IMF stand by.

\section{The adjustment program}

The Nigeria program has two main components: measures aimed at changing the structure of the economy and policies to support stabilization. While there is considerable interplay between the two, the focus of structural adjustment is on exchange rate and trade reforms, while monetary and fiscal 
policies are the important instruments of stabilization. The adjustment strategy is based on the assumption that external financing will permit Nigeria to run current account deficits and thereby to achieve higher import levels and growth rates than would otherwise be possible. In the spirit of the Baker Plan, the approach is to allow debt to increase, although at a slower rate than projected export growth, with the result that creditworthiness would be restored over time. Austerity is still necessary, for the oil price decline of 1986 sharply reduced export revenues. But the strategy allows Nigeria to avoid the further expenditure controls that would have otherwise been needed for a rapid restoration of creditworthiness.

Exchange rate reform. The centerpiece of the adjustment program is the shift to a market-determined foreign exchange rate for trade transactions, through the introduction of an auction system for the allocation of foreign exchange--the second-tier foreign exchange market (SFEM). At the inaugural SFEM auction on September 26, 1986, the value of the naira was discounted by 66 percent, trading vis-a-vis the US dollar at $\$ 1=N 4.6$ as against the administered rate of $\$ 1=$ N1.6. Initially held every week, fortnightly auctions have been the rule since April 1987. A shift has also been made to a "Dutch auction" system, whereby buyers pay their bid price, rather than the earlier system where each successful buyer paid only the marginal rate that exhausted the total amount being offered. The official, administered ("first tier") rate was kept for an interim period, with its use reserved for debt service and payments to international organizations. In accordance with the program, the two rates were unified in July 1987. Overall, the auction is working well and has become a generally accepted part of the economy. These are important achievements for a country that had long resisted outright devaluation.

In addition to the auction, SFEM encompasses transactions between authorized dealers and the private sector and an interbank market, which accommodates the recycling of foreign exchange initially purchased from private sources. The latter have become an important source of foreign exchange for the market; data for February 1987 suggest that proceeds from non-oil exports, remittances, invisibles, and capital transfers supplied to the market amounted to almost 50 percent of the auction sales for that month. This is an encouraging development, given the rather insignificant funding from such sources at the beginning of the SFEM.

Trade reform. Virtually all price controls and import licensing were abolished at the start of the SFEM, and the number of items subject to import prohibition was reduced from 74 to 16 . Under the program, the Government also abolished the temporary 30 percent import surcharge introduced in January 1986 and adopted an interim import duty and excise schedule. This reduced the dispersion of rates and the trade-weighted average customs duty from 35 percent to 25 percent. Some imports of agricultural and industrial products, which compete with the products of major domestic producers, still bear high nominal rates. Nevertheless, the removal of import licensing has transformed the protection regime, with the devalued exchange rate combined with more uniform and lower taniffs now providing protection for domestic producers. By far the most powerful change in export incentives under the program is the devaluation of the naira, while regulations carried over from the previous era of bureaucratic controls, such as prohibitions and export licensing requirements, have been reduced or removed.

Monetary policy plays a dual role in the adjustment program. For demand management purposes, monetary policy is to remain tight over the program period in order to prevent inflationary pressures from creating excessive demand for foreign exchange. In 1986 the broad money supply (M2) grew by only 2 percent; inflation was only half the level that had been projected in the program, and there was considerable upward pressure on interest rates. Recently, monetary policy has become expansionary. Monetary policy also has a structural component under the program, involving movements toward a more market-oriented financial system designed to facilitate the mobilization of financial savings and to encourage more efficient allocation of financial resources. Recognizing the need to give banks greater flexibility in their credit operations, the Government replaced the earlier extensive use of sector-specific credit targets with a simpler categorization which gives guidelines for the allocation of credits between priority activities for only half of the banks' lending. This is a further step in the deregulation of the financial system. Interest rate ceilings were also raised, thereby making it more profitable for banks to intermediate savings to potential investors and ensuring resources are devoted to more profitable projects.

Fiscal policy under the program was to combine a restrictive stance with measures to improve efficiency. The program aimed at keeping the federal budget deficit below 4 percent of GDP, with the devaluation facilitating the achievement of this target by sharply increasing the value of external petroleum receipts in naira terms. But in pursuing the fiscal balance target, certain general principles designed to enhance the effectiveness of public spending were to be followed including restraint on the growth of federal wage bill; an increase in material supplies to ensure adequate maintenance of infrastructure; and a reduction in subsidies to economic and quasi-economic parastatals. In the event, fiscal policies and control over public expenditures have proved the most difficult area of the program to implement, and there has been some slippage from the fiscal deficit target. This issue needs to be addressed in order to ensure the smooth implementation of the program, in particular its monetary and price objectives.

\section{Impact}

The changes in trade policy and the real exchange rate that accompanied the introduction of SFEM are likely to have their main effects on relative prices. Thus far, the program has had its greatest impact on the price of exports. Prices of import substitutes have risen to a lesser degree, since the effects of SFEM have been partly offset by removal of import restrictions and lower tariffs. The exchange rate and trade policy changes have had less effect on the prices of nontradable goods which, with domestic demand weak, have continued to decline both relatively and absolutely. The profound distortion in the relative price structure that was built into the economy during the oil boom years has now been largely corrected.

There was some concern in Nigeria that the introduction of SFEM, together with the removal of ex-factory price controls, would cause a resumption of high inflation rates. In the event, prices of grains fell sharply in late 1986, following a bumper harvest, and prices of other food products have increased only marginally. Prices of nonfood commodities have shown a mixed pattern, with modest increases for most items, basically because their retail prices largely reflected depreciated values before the introduction of SFEM. Prices for a few highly visible goods, such as automobiles, have risen sharply. But many prices actually fell somewhat during the first three months of SFEM operation, a trend that seems to have continued during the first quarter of 1987.

In agriculture, domestic prices for the principal cash crops-oil palm, cocoa, rubber, cotton, and groundnuts-used to be set by the respective Commodity Boards, which were dismantled in 1986. This move, together with the exchange rate change, greatly improved incentives for most of Nigeria's traditional cash crops, especially those whose prices had not been artificially supported by export 
subsidies or import restrictions accompanying the overvalued exchange rate. The immediate supply response has been strong for cocoa-the dominant non-oil export commodity-and rubber, with most existing trees reportedly now back in production. The longer-term supply response is still difficult to gauge; substantial new investment in additional capacity for tree crops with long gestation periods will require confidence in the sustainability of the present incentive framework.

The exchange rate adjustment and accompanying measures to liberalize trade have led to far-reaching changes in the incentive structure for industry. Previously, the Nigerian industrial sector had expanded largely in the direction of import substitution, influenced by the overvalued exchange rate which discouraged export production, and the tight limitations on actual imports. The program has reduced the previous bias against export activities. Incentives for producers of import substitutes, taken as a group, have been left broadly unchanged, although the exchange rate and trade liberalization measures have tended to affect individual producers in different ways, depending on the changes in tariffs and the share of local inputs in overall production costs. Broadly speaking, trade liberalization lowers the prices of imported final products, while depreciation of the exchange rate tends to raise them, as well as prices for imported inputs. For a given depreciation of the exchange rate and tariff reduction, the net effect on profitability of producing import substitutes will depend on the share of labor in production costs, since, in the short run at least, labor costs will not be directly affected by the exchange rate change. Hence, the larger the labor and local raw material share, the larger will be the increase in profitability.

Survey results tend to confirm these expectations. The more efficient local resource-based activities in manufacturing have felt a strong boost to their competitiveness. Import-dependent, assembly-type industries, on the other hand, have seen their costs escalate because of SFEM, while their competition from imports has increased, as a result of the freeing up of trade together with reductions in tariffs, and demand for their products fallen as a result of the recession that accompanied the drop in oil revenues. Some have closed down plants, adding to the unemployment problem. Most of the problems in manufacturing are in large, highly visible, urban-based firms which were developed behind protective tariff walls but were not, and will never be, efficient users of Nigeria's scarce resources. In fact, an inevitable outcome of a structural adjustment program designed to reorient production along the lines of comparative advantage is the restructuring or closing of such activities. The expansionary effects on industry of SFEM are likely-at least initially-to come from small companies based on local resources. These companies have limited visibility so far, particularly as the previous trade and exchange rate regime discouraged the development of a viable industrial export sector.

Notwithstanding serious transitional problems for some groups, the broad social impact of the adjustment program appears positive, particularly when seen in terms of the evolution of policy from "austerity alone to austerity with structural adjustment." The decline in economic activity that preceded the adjustment program increased unemployment and reduced per capita income. Without the program, the recession was projected to continue and even worsen, given developments in oil prices. By contrast, the large price boost that the adjustment program has given to exportables, and in particular the labor-intensive tree crops, has raised the demand for labor. This should help to forestall further increases in overall unemployment. As the effects of the program become more broadly felt, unemployment should begin to fall. Although the labor market adjustment process on the whole seems to be working, there is a transitional problem of mismatches between skills and job openings-the unemployed are school leavers and those with advanced training, while the jobs being created are for relatively unskilled rural workers.

\section{Conclusions}

While the response to the adjustment program in many areas has already been favorable, the domestic political situation is not an easy one, with the effects of continuing austerity and collapsing oil export revenues on imports and production partially obscuring the program's positive effects. Still, it is essential for Nigeria to persevere with present policies, for the recovery depends on availability of imports and, in turn, on export revenues and access to foreign financing. While oil revenues depend on factors that Nigeria can do little to influence, development of non-oil exports depends on the implementation of the adjustment program. The supply response to the improved incentives depends very much on entrepreneurs' confidence in a continuation of present policies. Moreover, should the Government lapse in its pursuit of reform and return to the previous policy regime of controls, external financing would be less forthcoming. The challenge ahead is to implement the remaining parts of the program and to maintain the reform momentum, thereby establishing the program's credibility in private markets.

Nigeria's prospects for growing out of the debt crisis are good. Assuming continued implementation of the program, Nigeria's debt crisis should subside over the medium term, as oil and non-oil exports grow. But until then, Nigeria will face a foreign borrowing constraint. This constraint, in turn, will limit the investment response to the structural adjustment program's changed incentive framework and constrain per capita income growth, particularly given the effects of desert encroachment and deteriorating soil fertility on agricultural prospects.

The Nigerian experience illustrates the importance of keeping public sector spending within "permanent income." This precept is difficult to implement for countries that depend, like Nigeria, on exports of a single commodity for the bulk of their foreign exchange. Indeed, if oil prices were to rise again dramatically, there would be pressures to use the proceeds for improving standards of living. However, these pressures should be accommodated only to the extent that increased revenues and spending are sustainable. With spending kept in check, painful austerity measures would not be required when prices decline again. This would also prevent the real exchange rate from appreciating unduly during periods of temporary increases in export revenues, thus avoiding costly shifts in the structure of production that would ultimately need to be reversed. This approach would also preclude foreign borrowing to finance consumption or investment in non-economic projects, which-while apparently affordable when oil prices are high-are not affordable from the perspective of permanent income.

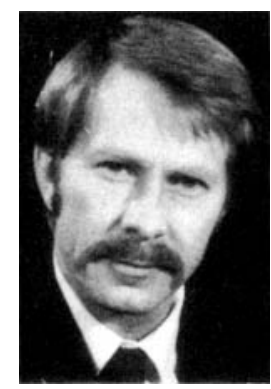

Nils Borje Tallroth Suedish, has a $P h D$ from Uppsala University. He taught there and worked at the Swedish Ministry of $\mathrm{Fi}$ nance before joining the Bank staff as a country economist. He now works on Nigeria. 


\title{
(DA) \\ Raising Resourees for IDA:
The Eighth Replenishment
}

\author{
A number of key policy issues were resolved during complex negotiations \\ that raised \$12.4 billion for the poorest developing countries
}

\author{
Alexander Fleming and Mary Oakes Smith
}

\begin{abstract}
$\mathbf{T}_{\mathrm{t}}$ he Intemational Development Association, an affiliate of the World Bank, was founded in 1960 to provide concessional long-term financing to its poorest member countries. Like the International Bank for Reconstruction and Development (IBRD), the main organ of the Bank Group, IDA provides assistance to high-priority investment projects and economic adjustment programs. While the terms of IDA are highly concessional, its projects are generally identical in scope and are appraised and implemented with the same rigor as IBRD projects. IDA differs from IBRD in eligibility criteria, terms of lending, and sources of funds.
\end{abstract}

Currently IDA is the largest single multilateral source of concessional assistance for low-income countries. During 1970-83 it provided 10 percent of the net official development assistance (ODA) flows from members of the OECD's Development Assistance Committee to countries with 1985 GNP per capita of $\$ 790$ or less. Within this eligible group, over 80 percent of IDA commitments have been made to countries with 1985 per capita incomes below $\$ 400$. In 1984-86 this share of IDA commitments increased to 96 percent. As IDA has grown, it has become an increasingly important source of finance in many recipient countries (see box "Flow of IDA credits"). This is especially true for the smaller countries of Africa and Asia, where IDA flows account for a significant portion of investment resources. Particular sectors, such as agriculture, transport, and power, have benefited greatly from IDA credits in these countries. But the impact of IDA extends beyond its contribution to investment financing. The influence of IDA on policy reform, on creating viable development institutions, and on general economic and sector analysis is perhaps its most important contribution to development in member countries.

While IBRD is financed by borrowings in the world's international capital markets backed by the capital subscribed by member governments, IDA is a fund periodically replenished by donors. Commitments of resources are made throughout the period of the replenishment, although actual disbursements to borrowers, and the corresponding contributions by donors, typically take place over a four-to ten-year period. IDA's resources are bolstered by reflows from the repayments of outstanding credits and by a periodic transfer of net income from the IBRD.

IDA donors as a group steadily increased their contributions to the Association through the first six replenishments. Then, for the first time, during the Seventh Replenishment, covering 1985-87, the total contributions dropped in both nominal and real terms. This fall reflected a concern in some donor countries about the size of their domestic budgets-especially the aid component-as well as a change in emphasis from multilateral to bilateral support. The Eighth Replenishment, therefore, was important to reaffirm to the development community and recipient countries the commitment of donors to IDA.

The negotiations to provide IDA with the resources it would need over fiscal years 1988-90 culminated in Rome in December 1986. The agreement provided IDA with $\$ 12.4$ billion, an increase of more than $\$ 3$ billion over the Seventh Replenishment. The agreement also reflected accord on a number of changes in key policy issues, such as the allocation of resources among main groups of borrowers, the terms of credits, the purposes of lending, and the relative sizes of contributions by donors (burden sharing). In order to gauge the significance of these changes, this article reviews briefly the background of the replenishment process.

\section{The negotiation process}

When IDA was established in 1960, donors provided an initial subscription of $\$ 750$ million. The demand for IDA resources was so great, however, that by 1962 it was clear more funding would be needed much earlier than expected. Members began negotiating a

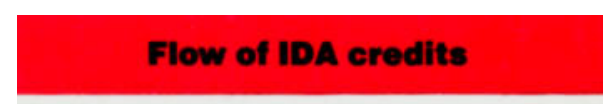

IDA has 131 member countries and through June 30, 1986 has extended $\$ 39.6$ billion in credits to 85 countries. Of the $\$ 3.14$ billion in credits committed in fiscal year 1986 July 1, 1985-June 30,1986$), 36$ percent went to Sub-Saharan African countries, 45 percent to South Asia, and the remainder elsewhere. Structural and sector adjustment lending, involving programs of economic policy reform, accounted for roughly half the commitments to African countries by IDA and a Special Facility for Sub-Saharan Africa over the past two fiscal years.

The poorest countries receive IDA credits, or credits from the other concessional facilities exclusively. Those countries with somewhat better creditworthiness receive a blend of IDA and IBRD loans; the latter carry near-market interest rates. Countries which move above an annual per capita income level of $\$ 790$, and are deemed creditworthy for Bank or commercial market loans, are no longer eligible for IDA credits. To date 28 countries have "graduated" from IDA; three of them, Colombia, the Republic of Korea, and Turkey are now IDA donor countries. 


\section{When does IDA8 become effective?}

Only when donors have secured the necessary budgetary allocations can IDA begin disbursing its resources. The principle of fair burden sharing applies in the implementation of the replenishment, however, as well as to the negotiations. Donors have tied the release of resources to similar action by other donors.

Under the IDA8 agreement donors will deposit with IDA an Instrument of Commitment indicating their commitment to make resources available to the Association. The replenishment, which is due to begin on July 1, 1987, will in practice become effective when IDA receives Instruments from donors representing at least 80 percent of the total replenishment amount. Such notification must also be received from at least 12 developed country donors.

Because the date of effectiveness might be delayed beyond the beginning of a new replenishment, advance contribution schemes have been devised. Under these, donors have agreed to make some proportion of their contributions (usually one third) payable and hence immediately available for commitment on credits prior to the effectiveness of the replenishment. The donors decided to use such a scheme in the context of IDA8. This advance contribution scheme would itself become effective under IDA8 once 20 percent of the resources for the basic replenishment have been formally "notified" (committed) by donors.

replenishment for the three fiscal years 1965-67, thus establishing the practice of preparing replenishments at three-year intervals.

The negotiation process itself extends over a year or more, depending on the number of issues raised and the complexity of the ultimate agreement. Formal negotiations are chaired by an appointee of the President of the World Bank; the appointee may, or may not, come from inside the Bank. In the IDA8 negotiations the then Senior Vice President for Finance at the World Bank, Moeen A. Qureshi, served as Chairman. The replenishment negotiations were supported by an IDA team in the Financial Studies Division of the Bank.

Each donor country is represented by a designated "Deputy," who is typically a representative from the treasury or foreign affairs ministry and is empowered to negotiate within the limits defined by his government. These limits are narrowed as the negotiation proceeds. The agreements reached by the Deputies take the form of recommendations for the approval of IDA's Board of Executive Directors. A report of the IDA negotiations and a draft resolution governing the IDA replenishment is forwarded by IDA's Executive Directors to the Association's Board of Governors-normally the finance ministers of member governments or their equivalents-for agreement. The negotiating process has never been easy. The size of the replenishment has always been the focal point of the negotiations and the positions of individual donors have reflected their own economic well-being and political priorities. Questions of burden sharing have often complicated the negotiations, as have the adjustment of voting rights, the terms to be attached to IDA credits, and the allocation of the Association's funds among the eligible borrowing countries.

\section{The IDA8 negotiations}

The IDA8 negotiations began with the disappointment of the IDA7 negotiations fresh in donors' minds; IDA7's $\$ 9$ billion replenishment had been lower than the previous replenishment of $\$ 12$ billion. From the outset of the IDA8 negotiations there was a very positive tone, characterized by a strong cooperative spirit among the Deputies. The IDA8 negotiations began with all donors reaffirming their support for a strong and adequately financed IDA. There were, nonetheless, divergent views on the size of the replenishment. A range of $\$ 10.5-\$ 12.5$ billion was established at an early point in the negotiation. This range reflected a balance between the perceived resource needs of the eligible countries over fiscal years 1988-90, and the budget realities of aid availability in many donor countries. Many donors would have preferred a figure above this range but were prepared to accept a figure toward the top end if that meant that the negotiations could be completed expeditiously and an interruption in the flow of resources to borrowing countries could be avoided.

The central issues of size, terms, and allocations were dealt with as a package. Gradually, as the negotiations proceeded, most donors agreed to aim for a replenishment of at least $\$ 12$ billion. To secure this figure, donors were prepared to accept some hardening of terms. Donors were also prepared to increase IDA's lending for adjustment support in order to secure broad-based agreement on an increased replenishment.

A number of donors played active roles in marshalling support for the Association and facilitating a successful conclusion to the negotiations. Several donors-among them the Nordic countries, the Netherlands, France, and Italy-promoted a replenishment in excess of $\$ 12$ billion. The United States played a key role in shaping the package of issues that ultimately led to a basic replenishment of $\$ 11.5$ billion and it released a part of its share capital in IBRD to accommodate other donors who wanted to increase their shares and were prepared to raise their contributions to IDA to do so. Japan contributed $\$ 450$ million more than its 18.7 percent share. Together these positive initiatives provided the incentive for other countries to increase their contributions.

\section{The outcome}

The main features of the IDA8 replenishment are reviewed below. For a summary of the various implementation arrangements, see box "When does IDA become effective?"

IDA8 size. After extensive deliberations, donors agreed on a basic IDA8 replenishment of $\$ 11.5$ billion with normal burden-sharing arrangements. Most donors, however, felt that a replenishment at the top end of the negotiating range would better facilitate the adjustment efforts and long-term investments required in many countries. Accordingly, a number of countries agreed to supplement their contributions: Japan, as noted above, provided an additional $\$ 450$ million; the Netherlands $\$ 125.5$ million; Italy $\$ 90.5$ million; Germany $\$ 50$ million; and the United Kingdom $\$ 15$ million. The Dutch and Italian supplementary contributions were in addition to increases in their shares in the basic IDA8 replenishment. Canada also agreed to make a special contribution of $\$ 28.75$ million which was also included in the basic IDA8 replenishment. The supplementary amounts were not made a permanent feature of future burdensharing arrangements. In addition, Switzerland (not a member of IDA) concluded a bilateral agreement with IDA for \$165 million as an untied grant in conjunction with the IDA8 replenishment. These supplementary resources brought the total funds available to IDA during the Eighth Replenishment to $\$ 12.4$ billion.

Burden sharing. In negotiating the basic $\$ 11.5$ billion replenishment, donors placed considerable importance on fair burden sharing (see Table 2 for shares of donors). Donors take a range of economic and political considerations into account in determining their shares. The important economic indicators include relative GNP and per capita GNP sizes. In IDA8 the United States and Japan maintained their IDA7 shares: 25 percent and 18.7 percent, respectively. Those of France, Canada, and Italy were increased significantly, while the Nordic countries, the Netherlands, Spain, Austria, New Zealand, and the Republic of Korea also agreed to take larger shares. Japan indicated that greater harmonization of its shareholdings in IBRD 
and IDA was required and that its IDA7 share in IDA8 could not be maintained without an increase in its share in IBRD. Italy, Canada, the Netherlands, and the Republic of Korea also made increases in their IDA contributions conditional on increases in their IBRD shareholdings. The United States, which held a limited amount of unsubscribed shares, agreed to give up some of its shares to accommodate three of these countries. Under this agreement the United States will release 2 percent of its total IBRD share capital to Japan, Italy, and Canada. Additional shares will also be allocated to the Netherlands and Korea, but from other sources as they become available. Subsequent to the

\begin{tabular}{|c|c|c|}
\hline \multicolumn{3}{|c|}{$\begin{array}{c}\text { Table } 1 \\
\text { Replenishment of IDA resources } \\
\text { 1961-90 } \\
\text { (In millions of US dollars') }\end{array}$} \\
\hline & $\begin{array}{c}\text { Basic } \\
\text { replenishment }\end{array}$ & $\begin{array}{c}\text { Additional } \\
\text { contribution }\end{array}$ \\
\hline Initial (1961-64) & 757 & \\
\hline IDA1 (1965-68) & 745 & \\
\hline IDA2 (1969-71) & 1,200 & $71^{2}$ \\
\hline IDA3 (1972-74) & 2,441 & \\
\hline IDA4 (1975-77) & 4,501 & \\
\hline IDA5 (1978-80) & 7,686 & $46^{2}$ \\
\hline IDA6 (1981-83) & 12,000 & $1,982^{3}$ \\
\hline IDA7 (1985-87) & 9,000 & $1,345^{4}$ \\
\hline IDA8 (1988-90) & 11,500 & $896^{5}$ \\
\hline
\end{tabular}

\begin{tabular}{|c|c|c|c|}
\hline \multicolumn{4}{|c|}{$\begin{array}{l}\text { Source: World Bank data. } \\
\text { In dollar terms established at the time of the } \\
\text { agreement. } \\
2 \text { Special contributions. } \\
{ }^{3} \text { The Fiscal Year } 1984 \text { Special Contribution. } \\
\text { whiche resources represent the African Facility } \\
\text { which was negotiated separately and after the IDA7 } \\
\text { replenishment was completed. These resources were } \\
\text { administered, however, by IDA. }\end{array}$} \\
\hline \multicolumn{4}{|c|}{$\begin{array}{c}\text { Table } 2 \\
\text { Changing contributions to IDA } \\
\text { (Percentage of total contributions) }\end{array}$} \\
\hline & $\begin{array}{c}\text { Initial } \\
(1961-64)\end{array}$ & $\begin{array}{c}\text { IDA7 } \\
(1985-87)\end{array}$ & $\begin{array}{c}\text { IDAB } \\
(1988-90)\end{array}$ \\
\hline \multicolumn{4}{|l|}{ United } \\
\hline \multicolumn{4}{|l|}{ United } \\
\hline Kingdom & 17.33 & 6.70 & 6.70 \\
\hline France & 7.00 & 6.60 & 7.30 \\
\hline Germany & 7.00 & 11.50 & 11.50 \\
\hline Canada & 5.00 & 4.50 & 5.00 \\
\hline Japan & 4.44 & 18.70 & 18.70 \\
\hline Italy & 2.40 & 4.30 & 5.30 \\
\hline \multicolumn{4}{|l|}{ Nordic } \\
\hline Group & 3.90 & 5.70 & 6.17 \\
\hline OPEC & 0.49 & 4.20 & 3.47 \\
\hline Others ${ }^{1}$ & 10.10 & 12.80 & 10.86 \\
\hline \multicolumn{4}{|c|}{$\begin{array}{l}\text { Source: World Bank data. } \\
\text { The complete list of IDAB donors, which includes } \\
\text { some countries that borrow from the Bank, is as } \\
\text { follows: Argentina, Australia, Austria, Belgium, Brazill, } \\
\text { Colombia, Greece, Hungary, Iretand, the Republic of } \\
\text { Korea, Luxembourg. Mexico, the Netherlands, New } \\
\text { Zealand, South Africa, Spain, Turkey, and Yugoslavia. }\end{array}$} \\
\hline
\end{tabular}

negotiation meetings, Turkey-another former IDA recipient-agreed to contribute to IDA for the first time, with a share in the replenishment of 0.09 percent.

Allocation of IDA8 resources. In allocating IDA8 resources among borrowers, donors were guided by established eligibility and allocation criteria. A per capita income of $\$ 790$ or less in 1985 and lack of creditworthiness remained the key factors. Donors supported the continued use of existing criteria-relative poverty, population size, and economic performance-for allocating resources among regions and countries. They agreed, however, to place greater emphasis on economic performance.

Two aspects of allocations were also discussed: allocations by country group of recipient and by type of lending operation. There was broad support for maintaining both the global character of IDA allocations and the financing of investments for long-term development as the mainstay of IDA operations. At the same time donors gave high priority to increasing resource flows from IDA to Sub-Saharan Africa, especially in support of programs of policy reform. Donors recognized that the problems facing Sub-Saharan Africa were of a protracted nature and would need the sustained support of the donor community. They agreed that a minimum of 45 percent and up to 50 percent of IDA8 resources should be made available to that region, depending on the progress made in their economic adjustment programs.

The donors also agreed to continue to support India and China, which receive a blend of IDA and IBRD funds, as well as other low-income countries outside Africa. Donors believed that despite considerable progress, India and China would continue to need inflows of foreign capital and technology to restructure and modernize their economies. Only by securing adequate concessional financing could they continue to meet their investment requirements and avoid excessive debtservice burdens. Concessional resources were also needed to alleviate persistent poverty in these countries. In nominal terms the donors agreed that India and China should not receive less than they had under IDA7, and that they should receive about 30 percent of IDA8 resources.

The donors, while wanting to maintain IDA as a lender primarily for investment purposes, placed greater emphasis on adjustment support lending in IDA8, especially in Sub-Saharan Africa, to improve the policy environment for investment. Between $\$ 3$ and $\$ 3.5$ billion of total IDA8 resources will be used for adjustment support and some of this will be used in conjunction with the IMF's new structural adjustment facility.

\section{Defining the grant element}

The grant element of a credit seeks to measure the concessionality of aid funds, extended at a given set of terms, as compared to the same funds extended as a grant (the benchmark). Five primary factors dictate the degree of concessionality of a credit: its interest rate, maturity, grace period, volume, and the relevant discount rate. The grant element in this article is defined as the difference between the present value of disbursements (disbursements are assumed to be made over an eight-year period) and all debt-service payments, divided by the present value of disbursements.

The change in IDA8 terms. one of the key policy issues discussed was the terms to be attached to IDA8 credits. This issue was closely linked to the size of IDA8. Some donors were prepared to accept a change in IDA's terms, provided this would enhance the size of the replenishment. Hardening terms, they felt, would lead to a more rapid recycling of IDA resources, thus enhancing the Association's ability to redirect its funds to areas of greatest need. Donors also generally recognized that IDA terms had grown considerably more concessional since the inception of IDA in 1960. Given that market interest rates were, in recent years, much higher, on average, than those prevailing in 1960, some donors supported restoring the concessionality of IDA credits to its original level.

Donors eventually agreed to reduce final maturities on IDA credits from 50 to 40 years for the least-developed IDA recipient countries-that is, eligible countries with insufficient creditworthiness to have any prospect of receiving IBRD loans or the least less developed countries (LLDCs) according to UN terminology that are IDA borrowers-and to 35 years for other recipients. Grace periods will be maintained, however, at 10 years for all countries. A reduction in final maturities from 50 to 40 years, with the grace period unchanged, will lead to a fall in the grant element from 81 percent to 77 percent (see box "Defining the grant element"). A further reduction in final maturities to 35 years reduces the grant element to 74 percent.

Under the existing terms of a 50-year credit, 55 percent of the face value of an IDA credit would reflow to the Association by the thirty-fifth year. In contrast, with the 40-year credit, 80 percent of the credit would reflow 
by the thirty-fifth year. With the 35 -year credit, of course, all of the credit would be repaid by the thirty-fifth year.

In reviewing IDA terms, donors also expressed concern that some countries that had graduated from IDA and had since made major economic strides still had outstanding IDA credits. Prompted by the importance of recycling IDA funds more quickly to those countries most in need, donors agreed that a provision be introduced for IDA8 credits and beyond that would permit terms to be reviewed and adjusted after a specified period to reflect changes in individual country circumstances. The changes in IDA terms agreed during the negotiations will apply only to credits committed to borrowers during the IDA8 replenishment period and beyond.

\section{Conclusion}

Agreement on a satisfactory replenishment was vital if the World Bank Group was to continue to meet the needs of an important group of developing countries: those Sub-

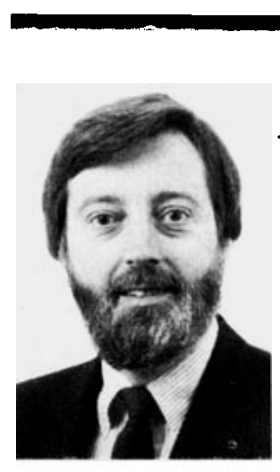

Alexander Fleming from the United Kingdom, is a Senior Economist in the Financial Policy and Risk Management Vice Presidency. Before joining the Bank staff in 1980, he was an Economist with the Bank of England.

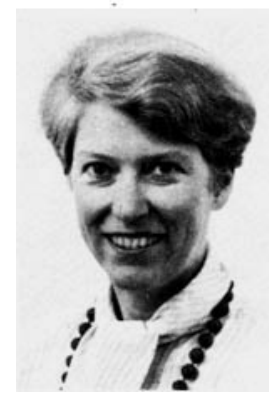

Mary Oakes Smith a US national, is Chief Officer, Replenishment Operations, in the Financial Policy and Risk Management Vice Presidency, An MIT Sloan Fellow, she joined the Bank's staff in 1969.
Saharan African, Asian, and other countries that are insufficiently creditworthy to borrow from the Bank Group entirely on IBRD terms. IDA is by no means a static institution. It must constantly adapt to changing perceptions of the types of policies and projects that will produce the most effective forms of development. It must direct its resources to countries where the problems of poverty are greatest and where resources can be used most efficiently. It must also adapt to the budgetary constraints in the donor countries that influence the availability of resources to the Association. All of these pressures are reflected, and ultimately resolved, within the replenishment negotiations.

Donors' budgetary constraints seem unlikely to ease in the near future. New replenishments are likely to follow the course set by the IDA 8 negotiations, with continuing emphasis on borrower performance, closer links with policy-based lending, and a greater share of resources being devoted to the least-developed countries.

\section{New From the International Monetary Fund}

\section{Staff Studies for the World Economic Outlook}

\author{
- Potential Output in Industrial Countries \\ - Capital Flight \\ - Import Intensity of Output Growth in Developing Countries \\ - Export Diversification in Developing Countries
}

Staff Studies brings together some of the background work that underlies the analysis and projections in the April 1987 issue of the World Economic Outlook. It is the latest in the Fund's series of World Economic and Financial Surveys, which carry regular studies by the Fund's staff on topical issues in the fields of finance and international economics.

Available from: Publication Services - Box A-873 International Monetary Fund - 700 19th Street, N.W. Washington, D.C 20431, U.S.A. • Telephone (202) 623-7430 Price: U.S. $\$ 15.00$ (regular) U.S. $\$ 11.00$ (university libraries, faculty, and students)

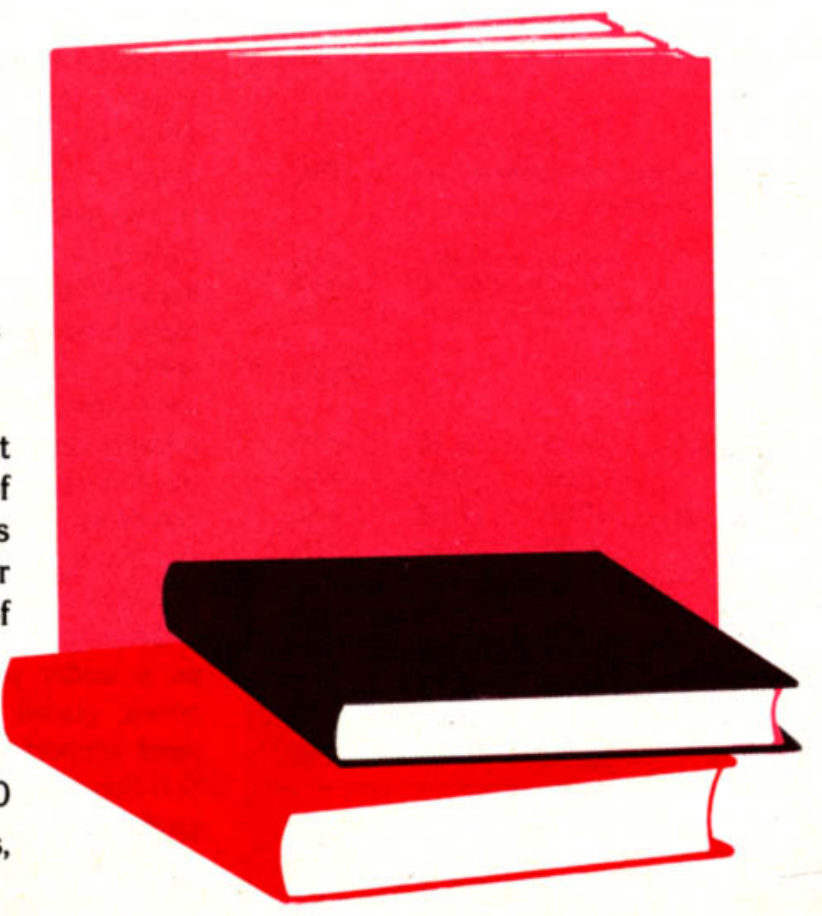




\title{
Issues in Capital Flows to Developing Countries
}

\author{
What influences the supply and demand for external finance in the 1980s?
}

\author{
Anthony Lanyi
}

$\mathbf{S}_{\mathrm{int}}$ financial community has been uncertain about how to provide debtor countries with the financing they need for adequate growth. Can and should private capital flows meet the demand? To what extent can official assistance replace private financing?

\section{Supply factors}

Some economists argue that if perfect markets prevailed throughout the world, private capital would naturally flow from the capital-rich North to the capital-poor South, equating at the margin the cost of funds in the North with the risk-adjusted rate of return in the South. But markets are not perfect. Besides, political risks in certain countries and long-term prospects for returns from certain infrastructural investments discourage commercial lending to support potentially profitable investments. This is a major argument for official development assistance (ODA) and other types of official financing.

In this analysis, ODA is treated as supplementing private capital flows. But the converse notion-that private capital flows supplement ODA-was voiced in the 1970 s, when ODA was not growing rapidly enough to meet the demands of developing countries for financial assistance. Even today, when there is little or no recourse to private capital markets for many potential borrowers in the South, the same argument is offered to support the urgent establishment of economic conditions that would permit restoration of "normal" creditor-debtor relationships.

Private capital. Private capital, mainly bank loans and bond purchases, was the principal source of external finance to developing countries from the early 1970s until recently. Private lending peaked in 1981 at $\$ 90$ billion (see table), declined sharply during 1982-83, and has continued downward ever since. Determinants of the supply of private finance are various and complex. The supply of bank financing seems to be mainly affected by economic growth in creditor countries and therefore in banks' total portfolios, and by economic performance in debtor countries, which influences the share of those countries' liabilities in banks' portfolios.

The cost to developing countries of bank loans is determined principally by the rate of interest in world financial markets. While spreads over the most commonly used index, the London Interbank Offered Rate (LIBOR) vary, such variations may not fully equalize the demand for and supply of funds to a country. While the prevailing interest rate is determined mainly by economic conditions in creditor countries, rates of return on investment in a debtor country do influence the supply of bank lending to that country. This influence is brought to bear on the banks' perception of the default risk and their desire to maintain a presence in the debtor country's economy, both of which affect the spreads on loans and banks' portfolio decisions. The risk element, which has dominated the reduction of lending in the $1980 \mathrm{~s}$, is, in turn, influenced by the debt-service burden and capacity of the borrowing country, its political stability, the effectiveness of its economic policies, and its prospects for export expansion and overall economic growth. The expected return on bank lending incorporates these risk elements.

Another influence on the external debt situation of developing countries has been the flow of deposits from these countries into the major financial centers; for two decades these centers have functioned increasingly as financial intermediaries for countries whose own financial systems have suffered from financial repression. The outflow of residents' saving to the major financial centers has starved domestic financial institutions of funds, leading to increased borrowing from external financial centers. This situation has been compounded in many instances by large fiscal deficits "crowding out" credit to the private sector.

Although in normal times it is good business for banks to lend to their own

This article is based on a longer paper presented at a conference on North-South cooperation sponsored by the Netherlands Ministry of Development Cooperation. The paper will be published in a forthcoming volume by Croom Helm Ltd. (Beckenham, U K). 


\begin{tabular}{|c|c|c|c|c|c|c|c|c|c|}
\hline \multicolumn{10}{|c|}{$\begin{array}{l}\text { Capital-importing developing countries: ex } \\
\qquad \text { (In billions of US dollars) }\end{array}$} \\
\hline & 1970 & 1975 & 1980 & 1981 & 1982 & 1983 & 1984 & 1985 & 1986 \\
\hline Current account deficit & 18.6 & 46.3 & 76.3 & 116.8 & 107.6 & 65.0 & 38.1 & 41.3 & 43.2 \\
\hline Nondebt-creating flows & 6.6 & 13.7 & 23.6 & 26.1 & 25.6 & 24.6 & 24.2 & 30.8 & 30.1 \\
\hline Official transfers & 3.0 & 7.6 & 12.5 & 13.6 & 13.0 & 14.0 & 14.2 & 16.7 & 17.0 \\
\hline Direct investment & 2.7 & 6.8 & 9.1 & 14.2 & 13.0 & 10.5 & 10.3 & 10.2 & 9.8 \\
\hline SDR allocations & 0.9 & -0.7 & 2.0 & -1.6 & -0.5 & 0.2 & -0.3 & 3.8 & 3.4 \\
\hline Use of reserves & 1.5 & -2.0 & -22.9 & 0.4 & 17.5 & -9.9 & -20.0 & -10.7 & -14.0 \\
\hline Asset transactions & -2.2 & -5.2 & -12.8 & -25.8 & -10.1 & -9.7 & -14.9 & -10.9 & -1.9 \\
\hline Errors and omissions & 0.1 & -7.2 & -16.1 & -18.9 & -25.3 & -9.9 & -2.2 & -5.4 & -2.1 \\
\hline Net borrowing & 12.7 & 47.0 & 104.4 & 134.9 & 99.9 & 69.8 & 51.1 & 37.5 & 31.2 \\
\hline Reserve-related & -0.5 & 2.5 & 2.5 & 12.3 & 25.7 & 21.4 & 7.3 & 0.4 & 3.2 \\
\hline Use of Fund credit & -0.5 & 2.1 & 1.4 & 6.1 & 6.7 & 11.2 & 4.9 & 0.3 & -2.2 \\
\hline Arrears & - & -0.1 & -0.7 & 5.6 & 15.7 & 12.3 & 3.2 & 0.1 & 5.2 \\
\hline Other & - & 0.4 & 1.8 & 0.6 & 3.3 & -2.1 & -0.8 & - & 0.1 \\
\hline Long-term official & 6.0 & 11.1 & 24.5 & 32.6 & 31.5 & 31.4 & 30.9 & 24.1 & 30.2 \\
\hline Other borrowing & 7.1 & 33.4 & 77.5 & 90.1 & 42.7 & 17.0 & 12.9 & 13.0 & -2.2 \\
\hline Long-term & 7.1 & 32.5 & 42.6 & 60.7 & 30.3 & 33.2 & 10.3 & 32.9 & 7.6 \\
\hline Banks & 3.1 & 20.5 & 24.8 & 30.8 & 18.9 & 33.9 & 9.9 & 61.0 & 9.9 \\
\hline Other & 4.1 & 12.0 & 17.8 & 29.9 & 11.4 & -0.7 & 0.4 & -28.1 & -2.4 \\
\hline Short-term & - & 0.9 & 34.9 & 29.4 & 12.4 & -16.1 & 2.5 & -19.9 & -9.8 \\
\hline
\end{tabular}

Sources: IMF; and Fund staff estimates

depositors, whether domestic or external, banks have nonetheless become reluctant to lend new money to depositors in countries with a debt-servicing problem. Regulators in some creditor countries have reinforced this reluctance by requiring banks to strengthen capital/asset ratios and to increase provisioning against risky loans. Meanwhile, however, they have continued to encourage concerted lending in specific cases.

For the immediate future, the amount and terms of commercial bank lending will depend in part on the types of lending instruments available. New lending might be encouraged by a secondary market for loan sales and swaps, which has already begun to develop. Other new financing arrangements include debt-equity conversions, long-term floating rate notes, use of cash reserve funds or zero-coupon hard currency bonds as collateral, and bank lending for export-oriented projects whose earnings could be earmarked for debt service.

Certain other innovations have, for the most part, only reached the discussion stage, although a few pilot arrangements are under way. These include investment by nonbank financial institutions in equity in developing countries, investment by multinationals or bank consortia in projects on the basis of shares of revenue or profit, and index-linked or commodity-linked bonds.

Some of the new arrangements highlight the possible substitutability between bank lending and foreign direct investment-that is, between debt and equity financing. The supply of foreign direct investment depends on economic growth in the host country, its political stability and macroeconomic policy environment, its location and export potential, and the institutional and policy features that either encourage or restrict foreign participation in domestic enterprises. In recent years more than half of new net foreign direct investment has gone to no more than three or four countries, and the existing stock of foreign direct investment is concentrated in a relatively small number of host countries. While these groups include some of the large and medium-sized developing countries, they exclude several large economies, such as China, India, and the Republic of Korea, that traditionally have limited large-scale foreign direct investment.

Official financing. The term "official financing" comprises concessional official development assistance and nonconcessional official development flows. The latter include officially guaranteed export credits and World Bank loans. ODA is directed largely to low-income countries; official development flows, to middle-income countries. (The use of Fund resources is not counted as development finance, but the extended Fund facility and Structural Adjustment Facility provide finance with maturities of up to ten years in support of growth-promoting adjustment policies.)

To the extent that ODA is simply motivated by the desire to support economic development efforts, there is, in principle, a link between the amount of aid offered particular countries and the social return to the corresponding investment. While the use of ODA is justified on the grounds that social return is larger than the private rate of return when the latter is too low to justify market borrowing, social return itself depends on many of the same factors that influence expected private profitability. A deterioration, for example, in growth prospects may weaken political support in donor countries for continued aid.

The flow of ODA is not determined solely by rates of return. Fiscal constraints and priorities in donor countries also influence the volume of official financing. Strategic political and military considerations often have played dominant roles in determining the direction of bilateral aid flows, as have humanitarian concerns and linkages between aid and promotion of the donor's exports. With respect to export promotion, a notable recent tendency is to combine export credits at commercially related terms with highly concessional assistance.

Substitutability and complementarity: $a$ creditor's view In the $1980 \mathrm{~s}$, private capital has not filled the gap between the financing needs of developing countries and the amount of official financing available. The volatile changes in bank lending have not been synchronized with the demand for external financing. Foreign direct investment and bonds have proved somewhat more stable, although as noted earlier, they have been available in substantial volume only to a rather small number of countries.

The view that ODA and official development flows should be regarded as a substitute for private financing has received some validation over the past several years during which official financing, to some extent, provided a safety net for debtor countries as private lending diminished. In the long run, however, the budgetary stringency that most donor countries face is likely to severely limit this process.

Private capital and official financing have commonly been considered complementary in the sense that private capital is best suited to financing foreign trade and projects with a relatively short gestation period as well as projects whose expected returns are commensurate with commercial rates of interest, while official financing is best suited for long-gestating (e.g., infrastructural) projects. For the private creditor, the latter projects carry the risk that the debtor might not be able to service medium-term debt on schedule, while concessional assistance used to finance commercially viable projects remains open to the criticism that it provides an 
unwarranted subsidy to activities that could have been privately financed at commercial terms.

\section{Demand for external finance}

Borrowing countries face basically two problems in attracting foreign capital. First, a large and positive net payment for factor services, such as interest payments to nonresidents, can "crowd out" imports and force a cutback in either investment or consumption. Second, net capital outflows increase the amount of foreign financing necessary to sustain desired investment. To the extent that increases in foreign borrowing are used merely to service earlier debt, the cost of such financing at the prevailing interest rate will be greater than the marginal social rate of return on additional investment being financed. There may be other social returns, such as the short-run benefits of averting politically difficult adjustment measures, but the result is a more severe debt-servicing problem in the future.

The demand for financing is also related to its cost. One would expect the demand for external financing to increase with a falling interest rate, reflecting a growing positive difference between private saving and investment. For heavily indebted borrowers, however, this effect may be more than offset by the need to obtain additional financing to cover higher debt-service payments when interest rates rise.

Considerations of debt management may also strongly influence and sometimes govern official demand for external finance. Unlike the private borrower, who is motivated solely by his own cost and the return he realizes from using borrowed funds, the official borrower must reckon with the macroeconomic effects of the overall increase in external indebtedness-including the indebtedness of private residents. When an economy's aggregate debt-service burden has risen rapidly, the government may decide to limit the further growth of external debt. It may do so by trimming public sector expenditures or by raising taxes; by taking steps to encourage private saving or to curtail private investment; by imposing direct limits on the private and public sectors on further borrowing abroad; and by attempting to reduce debtservice payments through agreements with creditors or unilaterally. Finally, in order to produce an outcome on the external side corresponding to the desired levels of domestic saving and investment, the government may have to take measures, such as exchange rate adjustments, to reduce imports and expand exports. Alternatively, in order to avoid the need to carry out such measures while at the same time maintaining debt- service payments, the government may decide to seek additional financing.

The demand for external finance may be influenced by the longer-term prospects of availability of such finance. For instance, a sharp increase in the availability of external finance or a fall in its cost would create an excess supply, inducing governments to reassess their need to finance government investments and/or fiscal deficits.

Substitutability and complementarity: $a$ debtor's view. External finance is to some degree fungible between the private and public sectors. For example, certain types of ODA may directly finance private sector activities; loans guaranteed by the debtor country government may be channeled directly to private borrowers (for example, export credits or sector loans of the World Bank); and some official borrowing may be on-lent to private borrowers. Moreover, additional ODA directed to the public sector frees domestic saving for financing private investment.

Nevertheless, a cutback in external finance will generally have different effects on the public and private sectors. When foreign commercial banks reduce their lending, the private sector may be affected more unfavorably than the public sector if the private sector has depended on foreign financial intermediation for much of its trade and investment credit, domestic residents continue to place saving abroad, and official lending covers a large part of the public sector's financing requirements.

Long-standing government policies affect the composition, and hence the substitutability, between different forms of external financing. Many countries limit foreign direct investment, often to avert foreign control of productive activities. Some governments have, at times, prohibited external commercial borrowing by the public sector and strictly controlled such borrowing by the private sector, because they considered the terms of the loans inappropriate for investment in a developing country, and because of fears that future debt-servicing requirements would limit the use of foreign exchange for essential purposes.

Official borrowers naturally prefer concessional ODA to other forms of external resources because of its concessional terms. A negative feature of some ODA, however, is that a large part of it is tied either to particular projects or to imports from the donor country. Certain types of relatively quick-disbursing and untied loans, notably World Bank structural adjustment and sectoral loans, are associated with policy conditions and nonconcessional terms.

In the 1970 s, borrowing from private sources was attractive because it was quickdisbursing and nonconditional and because, until 1979, real interest rates were low, even negative. Nevertheless, such borrowing by governments often created serious problems. Although the heavy borrowing of the 1970 s and early 1980s enabled developing economies to invest a larger proportion of their GDPs than might otherwise have been the case, much of it was used for consumption or to finance capital outflows. Furthermore, the returns on the additional investment did not necessarily accrue to the government or other public sector borrowers. Moreover, the terms and maturity of private financing do not always correspond to the timing of returns on the investment. In the case of infrastructural investment, long-run returns depend also on the ability of the government to meet the recurrent costs involved in maintaining the investment after its completion. For all these reasons, the authorities' ability to service the resulting external debt has necessitated raising additional revenue. Because tax revenues in developing countries are often inelastic with respect to output, tax rates have frequently had to be raised or new taxes introduced. An additional complication in many countries has been that inappropriate economic policies have led to inadequate growth of the capacity to generate the foreign exchange required for debt service.

A number of governments in heavily indebted countries have recently been more favorably inclined to nondebt-creating private capital flows and have limited borrowing from foreign commercial banks. While the latter tendency to some extent reflects simply limited availability of bank financing, there have been initiatives by governments to ease limitations on foreign direct investment and to carry out more rigorous adjustment policies to avoid a further worsening of their external position.

\section{Policy conditionality}

Both the Fund and Bank's policy conditionality and the management of ODA by donor country aid agencies involve requirements by lenders or donors that the resources be used in ways that meet certain purposes: improved financial stability and international competitiveness, which are especially emphasized in programs supported by the Fund and Bank; and productive investment and fulfillment of basic needs in the case of ODA (including, of course, financing from the Bank). These purposes are overlapping and complementary. A successful Fund-supported program or Bank structural adjustment loan should improve the overall macroeconomic environment and efficiency of resource allocation. Such improvements, in turn, should 
serve to raise returns on both official and private investment, including projects currently supported by ODA, as well as stimulate a greater inflow of foreign private resources.

Nevertheless, Fund-supported programs in particular have been criticized for having the effect of cutting back on development programs, because the fiscal adjustments required under stand-by arrangements usually have fallen heavily on government investment expenditure. To be sure, under programs supported by the Bank and Fund, painful choices have had to be made in reducing government expenditure. There has sometimes been considerable scope for cutting wasteful public investment projects. Harder choices must often be made among current expenditures. Some of these--such as in education, health, and maintenance of energy and transport infrastructure--are as crucial as is investment to sustaining and expanding output. But others, such as salaries and defense, are politically sensitive. Cutbacks in local outlays on investment and capital maintenance expenditures have naturally influenced the volume and direction of official financing.

\section{Donor coordination}

The lack of coordination of official financing originating from many different donor countries and institutions and the resulting lack of complementarity among individual loans or grants have long been obstacles to the efficient use of such assistance. (See "Aid coordination: a recipient's perspective" by Sven B. Kjellstrom and Ayite-Fily d'Almeida, Finance and Development, September 1986.) To be sure, the consultative groups of donors organized by the Bank have played a useful role. But because official financing generally complements the recipient countries' own resources, coordination also needs to come from within the recipient country, and this might best be accomplished by strengthening the Ministry responsible for coordinating external assistance. Of course, for some low-income countries, this will require a considerable degree of institution building, which by its very nature requires technical assistance from the outside.

The closer collaboration in recent years between the Bank and the Fund has strengthened aid coordination and its linkages with Fund-supported programs. The Bank and Fund jointly prepare economic policy framework papers in connection with the Fund's Structural Adjustment Facility. These papers are intended to help mobilize additional ODA and to coordinate ODA management. Although additional ODA is still at the discussion stage, aid agencies have expressed interest in using the policy papers as general guidelines for aid efforts.

\section{Prospects}

With the possible exception of Japan, it seems likely that the fiscal stance of donor countries will, in the immediate future, limit the growth of official financing in real terms. Prospects for increasing resources available to the Fund and World Bank are mixed. Meanwhile, overall nontrade-related lending by commercial banks has dipped, despite larger flows to a small number of countries with strong economic prospects.

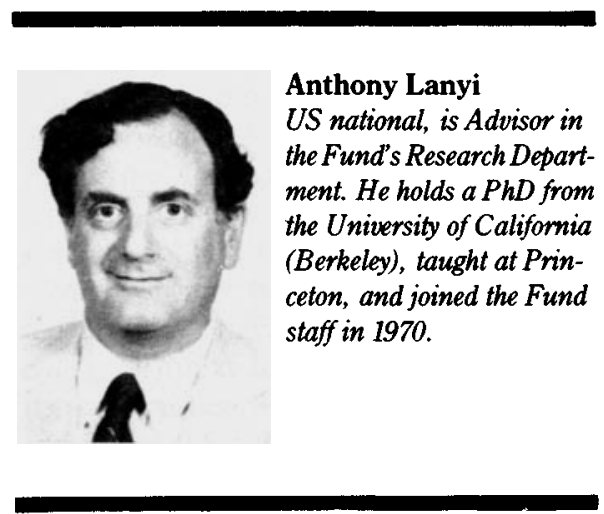

The ability of donor country governments to encourage, where appropriate, expanded private sector lending through official guarantees, banking regulation, and other devices is considerable. New financing of these types will not be forthcoming, however, unless warranted by adequate expected returns, which in turn will require a strong economic performance in debtor countries. Needless to say, such performance depends in considerable part on the growth and openness of foreign markets. Nevertheless, chronic policy failures and slow growth of donor countries have contributed to foreign banks' reducing new financing for many debtor countries and the weakening of political support for ODA and multilateral development banks. Conversely, strong recipient government policies, high levels of domestic saving and investment, and efficient use of domestic resources will attract external resources.

Appropriate policies may not be sufficient, however, in countries where existing debt, even if restructured, cannot be serviced without severely impeding future economic growth. Strengthening economic performance for countries with an excess demand for financing may require initial increases in financial assistance. Assuming such financing becomes available, the chief task will be to create an environment in which both public and private sectors use resources more efficiently. This is especially relevant to low-income countries, where political will and heavy doses of technical assistance are required, and where additional financing will need to be largely concessional.

The complementarity of official and private sources is heightened in these circumstances. Because the overall economic performance of a debtor country is so important for calculating expected returns to investment, private investors need the assurance that official donors, especially the Fund and World Bank, are offering advice and monitoring policies of the debtor countries.

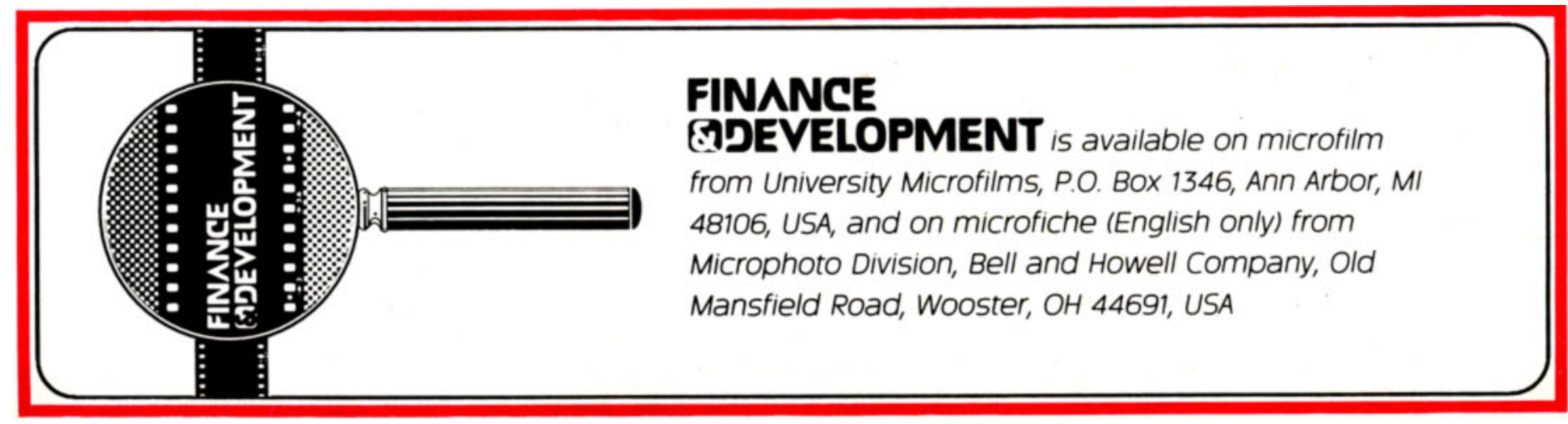




\title{
Financial Liberalization in Developing Countries
}

\author{
Why financial markets in LDCs are inefficient and how they can be improved
}

\author{
Michael P. Dooley and Donald J. Mathieson
}

\begin{abstract}
M any developing countries attempted during the 1970 s and 1980 s to increase the role of market forces in the determination of interest rates, the allocation of credit, and the overall scale of financial intermediation. These financial reforms, along the lines of similar efforts in industrial countries, were motivated both by a desire to improve the efficiency and stability of the financial system and by internal and external developments which made it increasingly difficult to maintain a tightly regulated financial system. However, unlike the experience of industrial countries, the process of financial liberalization in many developing countries has not produced a successful transition to more efficient and market-oriented financial systems. The explanation for this contrast in experience lies in the different nature of financial systems in developing countries.
\end{abstract}

\section{Financial repression}

Most developing countries have repressed financial systems and a relatively high degree of official regulation. While the administrative rules and regulations naturally differ across countries, there are certain elements which are a part of many regulatory structures.

Interest rates. Interest rate ceilings on lending and deposit rates exist in almost all developing countries. Such ceilings are often justified on the grounds that unfettered interest rates would tend to be abused by the oligopolistic owners of domestic financial institutions. These ceilings have in some countries resulted in highly negative real interest rates, especially in countries with rapid inflation, and a wide spread between loan and deposit rates. Such rates tend to be adjusted slowly to changing economic condi- tions and inflation and may provide little incentive to accumulate domestic financial instruments.

Portfolio selection. Restrictions on portfolio selection are the principal means of allocating the resources that flow through the organized financial sector in most LDCs. These restrictions often include required lending by financial institutions to specific activities, central bank rediscounting of credits to key sectors often at subsidized rates, and the control of financial intermediaries through direct ownership (see table).

These rationing schemes are unlikely to match available resources with the most productive sets of investments. "Instead, resources end up financing government deficits or flow to capital-intensive projects undertaken by large firms (often parastatals) whose domestic markets are protected by trade restrictions. Small- and medium-sized enterprises are then forced to seek out credit from the informal (unregulated) financial markets or, in the absence of access to both domestic and international financial markets, increasingly need to rely on self-financing. For such firms, the true "opportunity cost" of obtaining credit is far in excess of published loan interest rates. Moreover, in a regulated market, bank managers and loan officers face such a large excess demand for credit that they may not be forced by competition to market their product or to select among competing projects on the basis of rates of return.

Taxes and reserve requirements. The portfolio choices of financial institutions are also influenced by the existence of high liquidity and required reserve ratios; and the complex mix of explicit and implicit taxes and subsidies that the fiscal authorities impose on the financial system. Direct taxes on interest income, bank profits, and financial transactions in some cases represent important sources of tax revenues. Moreover, high reserve and liquidity ratios ensure a ready demand for government securities or "highpowered" money that can help finance the government deficit at given ceiling interest rates. This creates scope for significant inflation tax revenue, since banks are required to increase their holdings of reserves as the price level rises. At the same time, the authorities provide implicit subsidies for financial transactions in the form of deposit insurance and by acting as the lender of last resort.

Access to alternative financial markets. The regulations and taxes affecting the official financial system have created strong incentives for domestic bank and nonbank institutions to conduct their financial operations in external or informal domestic markets. Depositors are attracted to these alternative markets by higher yields, while borrowers find that they can obtain the credits they desire (even though at unsubsidized interest rates) which they cannot obtain in the domestic market because of credit rationing. Moreover, such financial transactions allow these institutions to escape the taxes imposed on financial market transactions in the formal sector. To prevent an erosion of this tax base, the authorities in most developing countries with repressed financial systems have traditionally placed extensive controls on both inflows and outflows of capital and have made contracts in the informal sector legally unenforceable.

Concentration and entry. Entry is gener- 


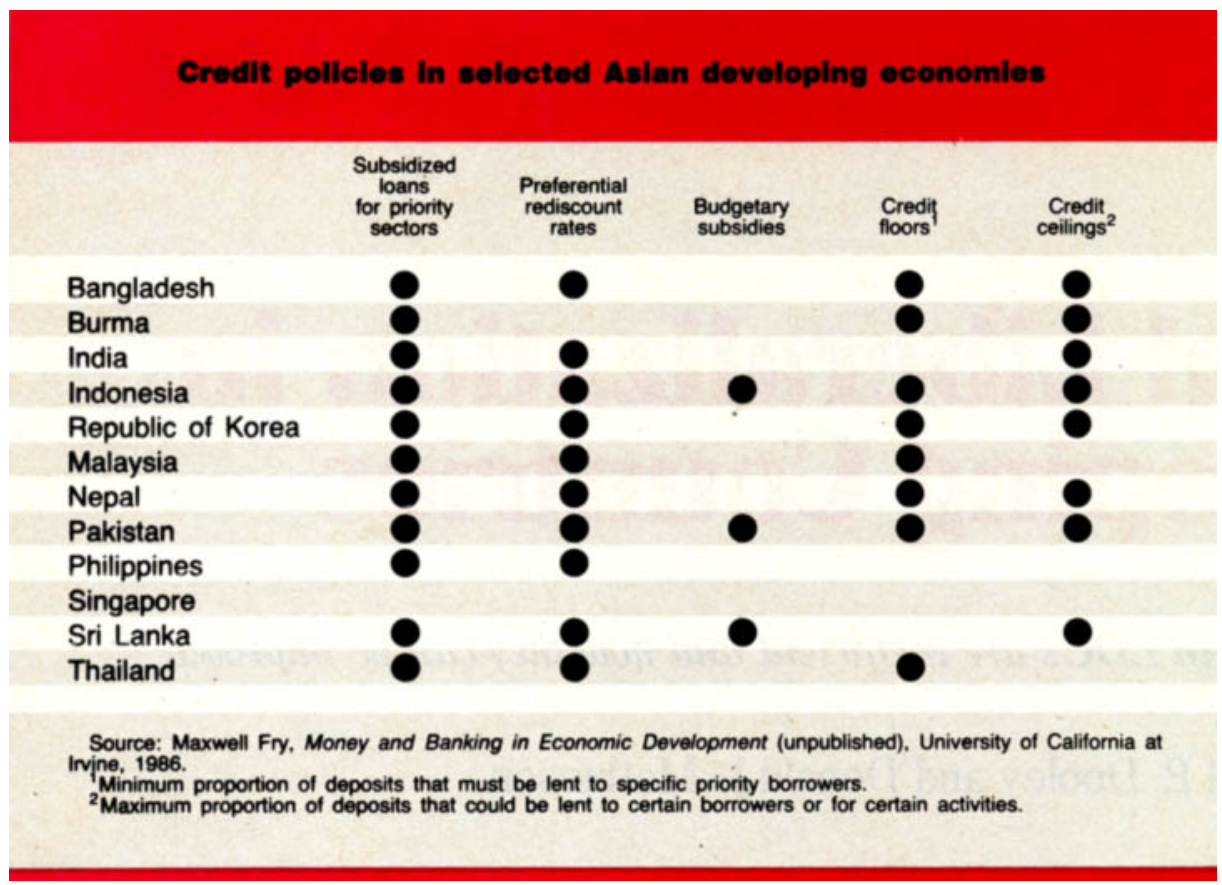

ally quite restricted, and the rights are typically granted to certain groups rather than auctioned to the highest bidder. This limitation on entry, plus restrictions on foreign ownership of domestic financial institutions, have often resulted in an oligopolistic structure for the regulated banking industry. The degree of concentration in the banking system in a group of Asian developing countries during the 1970s illustrates this situation rather graphically. A single bank held as much as one third of all deposits, and the largest four banks accounted for as much as three quarters of all deposits. In addition, ownership of the financial institutions has been linked in some countries to large industrial group holding companies.

\section{Implications of financial repression}

Authorities in developing countries often favor a repressed financial system since it allows them to exercise control over resource allocation and to tax financial intermediation. No matter how desirable those attributes may appear to the authorities, the costs that such a system imposes on the private sector may be less obvious but substantial.

Limits of diversification. Developing economies generally offer domestic residents relatively little opportunity to diversify their investment portfolios. In part, this reflects the fact that, in those economies which rely heavily on the export of only a few goods, or whose exports are sent to only a limited number of markets, economic activity in all sectors will be influenced by changes in either the price or volume of such exports. Given the controls which limit the access to foreign financial institutions from matching these demands and pooling risks and, therefore, from providing a full set of transformation services.

\section{Financial reforms}

The financial reforms undertaken in developing countries of Asia and Latin America during the past two decades have differed considerably with regard to the types of measures enacted, the speed of the liberalization, and the degree of coordination with other policy measures. The outcomes of these reforms have also varied, with some reforms being sustained over an extended period with relative stability (for example, in the Republic of Korea) but others ending in the midst of financial crises (for example, Argentina and Chile).

Much of the recent literature on financial reforms that ran into difficulties has focused on the origins of such difficulties, with particular attention to the interaction between liberalization of the goods markets (e.g., through tariff reduction) and liberalization of the financial markets. It has generally been argued that inconsistent macroeconomic policies were the main reason for the eventual failure of the reforms. Such inconsistencies were principally associated with the fact that goods and financial markets adjust at different speeds, and the real exchange rate changes that may be generated by a financial reform make the integration of domestic and foreign goods markets much more difficult.

The discussions of the macroeconomic policy coordination issues have led to some conclusions about the pace and order of reforms, for example that: (1) fiscal imbalances should be dealt with relatively early, since it is difficult to offset the adverse effects of financing large-scale deficits; (2) trade reforms (e.g., tariff reductions) should also take place early but there is considerable debate over whether these changes should occur quickly or be phased in gradually; and (3) extensive financial reforms should be phased in gradually in order to protect the domestic financial system during the transition. However, less attention has been devoted to measures that could be taken (other than better coordination of macroeconomic policies) to ensure a more efficient and stable financial system.

The authorities in many developing countries have enacted a broad spectrum of changes including lower required reserve ratios, removal of ceilings on interest rates for certain types of deposits, freer entry into the financial system, elimination of portfolio allocation rules, and relaxation of controls on external financial transactions. Although the potential benefits of such policies may be 
substantial over time, it is also important to consider short-run implications for financial stability in the context of a repressed financial system.

\section{The climate for reform}

In most developing countries some aspects of the repressed system are likely to remain in place throughout a reform effort. The residual role the authorities want to retain in allocating resources affects the nature of any reform effort. Another important factor is the willingness of the authorities to allow foreign institutions and markets to supply the financial intermediary services that are needed by the economy. Despite the efficiency arguments in favor of such moves, most countries have restricted the access of foreign financial institutions to the domestic markets, perhaps because of concerns about allowing the banking industry to be controlled by external owners. In addition, recent analyses of the financial reforms in the Southern Cone of Latin America have argued that the full integration of domestic and external financial markets may have to be delayed until inflation is under control and the domestic financial system has been made more competitive.

As mentioned earlier, taxes on financial intermediation have been quite an important source of fiscal revenues in developing countries. In addition, there is in some cases a strong political commitment to tax relatively wealthy members of these societies. For both these reasons, deregulation of financial markets is often a more difficult problem for governments of developing countries in comparison with developed countries.

Another factor that will influence financial reform in developing countries is that the institutional arrangements surrounding financial markets in industrial countries are not evident in the "typical" financial system in the developing world. For example, in a system in which domestic credit is channeled through the banks, there is usually only a small traded equity market. Moreover, in a repressed system there is no demand for private credit rating services, public regulatory bodies such as the Securities and Exchange Commission in the United States, or uniform accounting standards and practices. Such institutional arrangements are an integral part of credit markets in industrial countries but, at least initially, are not well established in developing countries. Since regulations severely limit the investment choices of the managers of financial institutions in developing countries, there is no obvious reason to separate the ownership of financial institutions from the industrial firms to which the banks lend. For similar reasons, a competitive structure for the banking system is also not an important policy objective. Finally, the role of bank regulation and examination of insured intermediaries is also quite different from that of industrial countries. In a typical system before reforms, regulators seek only to ensure that the banks are not engaged in fraud, and that they conform to the government's guidelines on credit expansion.

Given these structural differences between developed and developing countries, liberalization of the banking system in a developing country can expose several potential trouble spots.

Prudential risks. One of the traditional goals of supervision of bank portfolios in industrial countries has been to ensure that the bank's assets do not become too concentrated in a single firm or subject to a common source of risk. The objective is difficult to achieve in a developing country because of the prevalence of joint ownership of banks and other businesses. In addition, all of the bank's potential customers within such countries may be equally affected by shocks to commodity prices or crop conditions. Moreover, national income for such countries may display a higher variance than that in industrial countries for a host of economic and political reasons. Thus, it may be impossible for banks to diversify their asset portfolios if they are limited to domestic credits. Ironically, the acquisition of foreign assets may be considered capital flight and be interpreted as a weakening rather than a needed strengthening of the financial structure of banks in developing countries.

Concentration of ownership. Another factor influencing portfolio selection in a newly liberalized system is that initially there is substantial joint ownership of financial, industrial, and commercial firms. Such holding companies or groups may be ill-equipped to adjust quickly to a market-determined cost of credit--particularly if they have for a long time received favorable treatment under the previous regime. In such cases, banks may extend credit to related firms that are not viable in order to protect for a time their own capital.

Deposit insurance and moral hazard. A familiar problem in industrial countries that may be even more serious in a newly liberalized system in developing countries is the moral hazard generated by insurance of bank liabilities. It may not be credible for a government that has historically been deeply involved with credit allocation to limit its commitment to maintain the solvency of both the banks and their commercial debtors. The political pressure to rescue both financial intermediaries and their customers that become insolvent may be impossible to resist, as has been illustrated in the recent experiences of a number of Latin American countries.

\section{Supervision and regulation}

As a result of these problems, and rather paradoxically, the role of supervision and regulation of financial intermediaries becomes much more important as a financial reform is undertaken. In a newly liberalized system, one should not assume that such a supervisory framework exists or will develop rapidly. At a minimum, it will take time, and perhaps painful experience, to show how such institutions must be structured in developing countries.

Clearly the establishment of a system of supervision and regulation would have to be adjusted over time as the reform progresses, inflation is reduced, restrictions on capital account transactions are relaxed, and the institutional structure is changed. Nonetheless, certain supervisory features would be expected to endure.

Diversification and asset selection. Although the financial reform will broaden the portfolio choices of both banks and nonbanks, a key task is to identify the limits on portfolio selection required to promote financial stability. Given the traditional linkages between banks and industrial firms, diversification of domestic risks calls for limitations on the proportion of total loans going to single firms (either individually or as part of a group) and possibly for limitations on the types of businesses to which banks could lend. It is also important to regulate and monitor the banks' lending to commercial enterprises in which they have an equity interest.

Liability selection. Since their ability to diversify portfolio risks is limited by capital controls, banks may be unable to offer liabilities to the public with a much more stable value than their current assets. Financial institutions that offer fixed par-value liabilities should be required to hold a corresponding amount of short-term government securities. Alternatively, financial institutions may be required to offer a larger share of assets that have some element of equity participation in the fortunes of the bank. The share of par-value deposits, the nominal value of which are independent of the market value of the banks' assets, may, therefore, have to be much smaller than those typical of banks in industrial countries. Bank regulations should, therefore, be structured to allow at least for the use of such nonpar-value deposits.

Foreign currency exposure. Similar considerations suggest that the foreign currency exposure of domestic financial intermediaries be monitored carefully and perhaps regulated. Such monitoring will become relatively more 
important as the limitations to access on foreign markets are relaxed. Thus, a requirement that foreign currency risk be fully hedged might be useful.

\section{Preconditions for success}

Several preconditions are necessary for a successful reform in which supervisory policy can play a stabilizing role. First, fiscal problems, including those emerging from the loss of tax revenues, must be resolved. Liberalization will not, in itself, improve the fiscal position of the government. In general, no liberalization scheme is likely to work if it is accompanied by increasing inflation rates that result in part from a reduced ability to tax financial intermediation.

Second, to the extent that the flight from domestic financial investments has led to an increase in gross external debt, there is the need both to coordinate financial reforms with other structural reforms (e.g., tariff reductions) and to limit the speed at which domestic and international financial markets are integrated (in order to avoid capital flows that lead to real exchange rate movements, making it more difficult for the trade reform to proceed). Moreover, domestic debtors should be allowed to hedge their exchange rate and interest rate risks or be offered some protection against them. Without such hedging possibilities, the financial reform

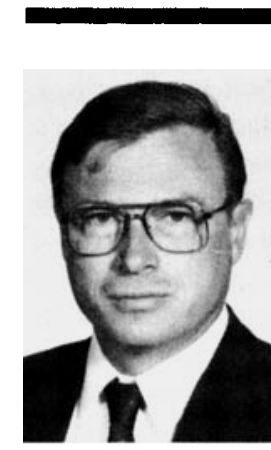

Michael P. Dooley a US citizen, is Chief of the External Adjustment Division in the Fund's Research Department. He is a graduate of Duquesne University, the University of Delauare, and Pennsyluania State University.

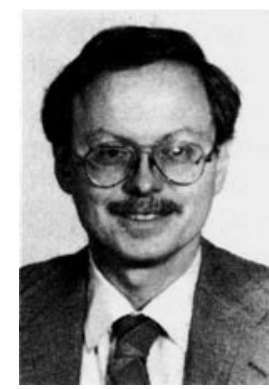

Donald J. Mathieson a US citizen, is Chief of the Financial Studies Division in the Fund's Research Department. Educated at the University of Illinois and Stanford, he taught at Columbia before coming to the Fund in 1975. process could be readily destabilized as a result of significant exchange rate or international interest rate movements.

Third, supervisory policy should be used at least to limit the banks' commitment of funds to risky enterprises, especially within the same holding company. The potential insolvency of nonbank enterprises under a market-oriented system may necessitate special subsidies or purchases of shares by the government in such firms. But these subsidies should be arranged through the normal fiscal accounts rather than through the financial system.

The initial changes in supervisory policy could focus on measures which would strengthen the audit process to prevent fraud, improve the diversification of portfolio risks, allow for nonpar-value deposits and substantial backing for par-value deposits, and strengthen bank capital positions.

None of these supervisory policies will be easy to implement in a developing country. However, the "typical" institutional arrangements that have marked developing countries may rot be able to survive in an open and highly competitive international financial environment.

\section{INTERNATIONAL MONETARY FUND TWO NEW OCCASIONAL PAPERS}

\section{Structural Reform, Stabilization, and Growth in Turkey}

by George Kopits

Number 52 in the Fund's Occasional Paper series, this paper records the performance of Turkey after its severe balance of payments crisis in the late 1970s. The analysis shows how Turkey combined short-term stabilization measures with efforts to achieve longer-term structural change in its productive sectors, and turned its current account around by 1985, sharply reducing inflation rates, and raising GNP growth.

\section{Floating Exchange Rates in Developing Countries: Experience with Auction and Interbank Markets}

by Peter J. Quirk, Benedicte Vibe Christensen, Kyung-Mo Huh, and Toshiko Sasaki

A review of the exchange market arrangements of developing countries that have used auction and interbank markets as a method for floating their currencies. This paper, published as Occasional Paper No. 53, summarizes the recent experience with these relatively new instruments and their economic implications.

Price: US\$7.50 (US\$4.50 to university libraries, faculty members, and students)

Available from: Publication Services - Box No. A-873

International Monetary Fund • 700 19th Street, N.W.

Washington, D.C. 20431, U.S.A. • Telephone: (202) 623-7430 


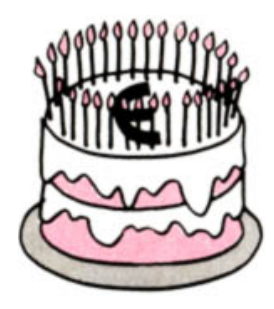

\section{The European Community: On the Road to Integration}

\section{The European Community has made important, though uneven, progress toward European unity during its first 30 years; its most significant life may lie ahead}

Augusto Lopez-Claros

W ith the accession of Portugal and Spain on January 1, 1986, the European Community (EC) now includes 12 member states covering most of Western and Southern Europe (see "Evolution of the European Community," Finance \& Development, September 1986). Its combined population, in excess of 320 million, makes it the world's largest trading bloc. In terms of GDP, the EC is second only to the United States. Established in 1957 by the six founding members of the European Coal and Steel Community, the EC has, in its first 30 years of existence, not only grown in size and influence but, by facilitating the process of economic integration between its members, also made a significant contribution toward strengthening European political unity, its original and foremost objective. The thirtieth anniversary of the signing of the Treaties of Rome establishing the various EC entities provides an appropriate occasion to review the Community's origins, its most important accomplishments and remaining weaknesses, and the prospects for the creation of a single unified economic entity within the next decade.

\section{Early days}

Earlier calls for political unification in Europe, in the 1920s, had made little headway against the firm allegiance of most governments to the concept of inviolable and indivisible national sovereignty. It was only after World War II, with its attendant destruction and economic collapse, that governments appeared ready to begin to develop the mechanisms which would bring about a greater degree of cooperation among European nations. Indeed, cooperation and unity began to be perceived as essential prerequisites for economic growth and prosperity.

The fundamental question was how to allow the German economy-with its key coal, iron, and steel sectors, so important in any war effort-to make a contribution to the recovery of Europe without jeopardizing its future peace. A plan, elaborated by Jean Monnet and put forward by Robert Schuman, the French Foreign Minister, on May 9, 1950, proposed the creation of a common market for FrancoGerman coal, iron, and steel products under a joint authority. Other countries were invited to participate in the creation of such a market and in April 1951 Belgium, France, Germany, Italy, Luxembourg, and the Netherlands signed a treaty establishing the European Coal and Steel Community (ECSC).

The main features of the ECSC were to place all coal, iron, and steel industries under the control of a supranational High Authority whose powers included the setting of production quotas for all member countries, the financing of retraining schemes for redundant workers, and the laying out of certain rules to prevent unfair competition. Important institutional provisions included the creation of a Council of Ministers empowered to take certain major decisions, a parliamentary assembly to add a measure of democratic control, and a European Court of Justice to ensure compliance with the provisions of the Treaty.

The establishment of the ECSC was not seen as an end in itself, but rather as a first step in a lengthy process which had the potential to lead toward greater economic and political integration. At about the time that the ECSC Treaty was signed, for instance, France proposed the creation of a European Defense Community to bring the armed forces of Europe under the control of a federal authority. As this would have entailed the existence of a common foreign policy, a proposal was considered by the members to create a new Community with powers in the areas of foreign affairs, defense, economic and social integration, and human rights. But the ensuing debate showed that there were significant differences among member states in the degree of commitment to the principle of integration and in the extent to which each was willing to cede sovereignty in specific areas.

The failure to establish a viable European Defense Community, however, convinced the ECSC countries that European integration would have to proceed with less ambitious objectives in mind. To this end the Foreign Ministers of the ECSC countries appointed a committee-under the chairmanship of Paul-Henri Spaak, the Belgian Foreign Minister-to look into the issue of further integration and, in mid-1956, the committee's proposals were approved and intergovernmental negotiations set in motion with the aim of establishing the European Atomic Energy Commission (Euroatom) and the European Economic Community (EEC). The Treaties of Rome establishing these two institutions were signed by the Six on March 25, 1957; 
together with the earlier ECSC Treaty they form the constitution of the European Communities.

\section{The Common Market}

The EEC Treaty sought the establishment of a common market, free of trade barriers, in which goods, services, labor, and capital would move without hindrance across national boundaries. The economic rationale for such a market was firmly grounded on the principle that international trade among countries with different resource endowments is mutually beneficial to all of them, and that specialization based on comparative advantage leads to greater efficiency in resource allocation and thus raises the overall level of welfare. Further, a larger market may provide firms with the advantages of economies of scale in production, marketing, and research and development.

The initial step taken to create a common market involved two elements. One was the elimination of customs duties, equivalent taxes, and quota restrictions on intra-member state trade; the other was the establishment of uniform custom duties for goods entering any member state from third countries. To achieve these ends the EEC Treaty set a timetable for the gradual reduction of tariffs over a 12-year period, a process which was to culminate in the establishment of a common external tariff (CET) for imports from nonmember countries. This was achieved in mid-1968, 18 months ahead of schedule. When Denmark, Ireland, and the United Kingdom joined the Community in 1973 (and when Greece became a member in 1981) they were given five-year transition periods to dismantle tariff and nontariff protection. Portugal and Spain, upon joining in 1986, were granted seven-year periods to adapt.

The gradual but widespread reduction of tariff protection (including lowering of the CET) contributed to an enormous expansion in the volume of both intra-EEC trade and trade vis-a-vis the rest of the world. Between 1958 and 1985 intra-EEC exports as a proportion of total exports for the ten members rose from 35 percent to 53 percent, while the ratio of intra-community exports to GDP rose from 4.9 percent to 14 percent. The EC countries are among the most open economies of the world as measured by the ratios of trade to GDP. Between 1958 and 1985 , for instance, the ratio of imports of goods and services to GDP for the Ten rose from about 19 percent to 32.4 percent. The corresponding ratios in 1985 for the United States and Japan were 10.2 percent and 11.7 percent, respectively. By 1985 the EC had become the largest trading bloc in the world accounting for approximately 20 percent of total imports and exports (excluding intracommunity trade).

Notwithstanding the rapid expansion of trade, there are a number of factors that have prevented the emergence of a fully developed internal market. These include differences in customs formalities and differences in health and safety requirements; such practices introduce price differences for the same good insofar as imports from third countries are concerned. The Treaty's original declaration that member states could, under certain circumstances, maintain quantitative restrictions on the grounds of "public morality, public policy, or public security," health, or the "protection of industrial or commercial property" has been sometimes used to erect protectionist barriers, thus obstructing the achievement of a free internal market.

An important step toward the creation of a unified internal market was taken in 1985 when the Heads of State of the member countries endorsed the recommendations put forward by the Commission for the completion of the internal market. A detailed legislative agenda was drafted-affecting trade in goods and services, labor and capital mobility, transport, and the harmonization of laws and regulations-and is to be implemented by 1992 .

\section{Labor mobility}

The Treaties of Rome provide for the free mobility of the factors of production across national boundaries. Community workers should not be discriminated against on the basis of nationality and should enjoy equal rights and privileges in regard to employment, remuneration, and other working conditions. The free mobility of labor was implemented by the Community in a number of stages, between 1961 and 1968, by which time free labor mobility became a reality. The progressive relaxation of national controls was accompanied by complementary measures to remove other possible barriers to labor movement. Foremost among these was the right of a worker to transfer social security rights to another member state. In time, migrant workers became eligible to receive the same social security benefits as national workers, and periods of employment and contributions made in two or more member states could be aggregated for the purpose of determining the appropriate level of benefits.

The distortions that could have come about as a result of the different levels of national taxation-with labor presumably moving to low-tax member countries-have not materialized. Language and other cultural differences may have thus far acted as the most important disincentive for a greater degree of labor mobility. At the same time the $1970 \mathrm{~s}$ and 1980s have witnessed a steady deterioration of labor market conditions in virtually all of the member countries, with the average rate of unemployment in 1985 being about 9 percentage points higher than in 1970 . Nevertheless the free mobility of labor is a reality within the boundaries of the $\mathrm{EC}$ (it is to be achieved by 1992 with respect to Spain and Portugal) and stands as one of the most significant accomplishments of the EC's first 30 years.

\section{Services}

The Treaties of Rome also called for the elimination of restrictions that might prevent self-employed individuals and firms from setting up facilities and providing services in other countries. The freedom to supply services across national boundaries appeared to be a natural adjunct to the freedom of movement for goods which the gradual dismantling of tariffs and quotas was intended to accomplish. Equal rights of access to work in other member states were guaranteed on a nondiscriminatory basis, that is on the same conditions as applied to nationals.

This general principle notwithstanding, certain obstacles emerged that prevented the full implementation of the measures called for in the Treaties. In the case of the professions, for instance-the health sciences perhaps being the best example-the existence of differing licensing requirements laid down by each member state, as well as the right of members to enact certain types of protective legislation (for example, for purposes of consumer protection) led to substantial delays in the creation of mechanisms that might allow professionals to move freely between member states. There have also been obstacles to the provision of insurance across national boundaries. Thus an insurance company wishing to establish a branch in another member state could do so only if it satisfied all the conditions-as regards reserves, margins of solvency, etc., which were sometimes more stringent than those existing in the home country-demanded by the host government.

The progress made thus far on the freedom to supply services across national boundaries has been considerably slower than that achieved for the free movement of goods. The need to speed up the establishment of a common market in services is underscored by the increasing relative importance of the services sector within the Community, both in terms of value added and employment prospects. By the mid-1980s services in the Community accounted for over 55 percent of value added while the manufacturing sector's contribution had fallen to around 25 percent. The steady decline of employment in industry 
over the past decade likewise stands in sharp contrast to the healthy growth of employment in both the traditional services sectorbanking, insurance, transport-and those associated with the development of new technologies, such as information and data processing, computerized marketing and distribution, and audiovisual services. The completion of the internal market by 1992 should help remove the present obstacles to the provision of services across national boundaries and thus contribute to a more efficient allocation of resources within the Community.

\section{The European Monetary System}

The gradual establishment of a common market strengthened the bonds of economic interdependence between the member states and began to impose certain limitations upon the pursuit of national economic policy objectives. Economic policy measures implemented by each member state began to have a much greater impact upon its partners than at any other time in the past. This greater interdependence in time gave rise to the Community's first attempt at monetary integration, the Werner Plan of 1970 (named after Luxembourg's Prime Minister), an ambitious attempt to establish a monetary union by the end of the decade. Although a Community exchange rate system was established in April of 1972, the floating of the dollar in 1973 and the emergence of important divergences in economic policies among member states in the wake of the first oil crisis, led to the system's gradual shrinking into a deutsche mark zone.

The creation of the European Monetary System in March 1979 has proved to be a far more successful attempt at monetary cooperation. Participating currencies in the EMS exchange rate mechanism were to maintain $21 / 4$ percent margins of fluctuation around bilateral central rates (the margin for the Italian lira was 6 percent) expressed in terms of the ECU (European Currency Unit), a basket of fixed amounts of the currencies of EC member countries. The ECU serves as the indicator to determine the magnitude of one currency's deviation from the others, and as the unit of account for all interventions and transactions under the credit facilities. It is also being increasingly used in private sector transactions. Originally conceived as a way of stabilizing exchange rate fluctuations and thus reducing uncertainty for traders and investors, the EMS has contributed to a significant reduction in the variability of nominal exchange rates and a convergence of prices and costs among member countries. The average rate of inflation in the EMS group of countries-all the 1979 members except the United Kingdom, whose currency is included in the ECU but not in the exchange rate mechanism-has fallen steadily from 11.3 percent in 1980 to 2.5 percent in 1986 . Nominal wages and unit labor costs have likewise exhibited a marked degree of convergence.

The success of the EMS notwithstanding, the progress made thus far in the area of monetary cooperation falls short of the Werner Plan's original objectives which, inter alia, proposed the creation of a Community central banking system with ample executive responsibilities in the area of Community monetary policy. The completion of the internal market is likely to test the strength of the EMS in coming years as remaining exchange controls are removed and the process of capital liberalization continues.

\section{Agriculture}

Agriculture is the most important sector in which the Community has sought to evolve a common policy, in accordance with the specific sectoral objectives set out in the Treaties of Rome. The objectives of the policy have included increased productivity, a "fair" income for the agricultural population, the stabilization of markets, the ensuring of adequate supplies, and the maintenance of reasonable prices for consumers. Given the scope for potential conflict between these various aims-the improvement of farm incomes versus the interests of consumers, or self-sufficiency versus the access of nonmember countries to the EEC market also provided for in the Treaty-it is perhaps not surprising that the system which eventually emerged was a delicate compromise between opposing interests. These were, on the one hand, the national interests-as represented by the ministers at the Council-with economically important and politically powerful agricultural constituencies, and the European interest as seen by the Commission, on the other.

The main instrument of the EC's Common Agricultural Policy (CAP) has been an elaborate system of price supports which would simultaneously provide an adequate remuneration to farmers and insulate the market from undesirable price fluctuations. The intervention mechanism involves three types of prices: target prices, which are deemed to be consistent with the goal of supporting farmers' incomes; intervention prices at which official support-buying by the Community-in unlimited quantities--takes off the market excess supplies and thus provides farmers with a minimum guaranteed income; and threshold prices which are applied to imports from nonmember countries and thus provide a measure of protection. In addition to these, in the 1970 s a system of border tariffs and subsidies was introduced to offset the effects of exchange rate changes on the level of support prices expressed in national currency terms. These adjustments at the border, known as monetary compensatory amounts, arose out of the disorderly conditions then prevailing in the exchange markets and, although they were expected to be of a temporary nature, remain firmly in place today.

The price support operations as well as those aimed at structural reforms are financed through the European Agricultural Guidance and Guarantee Fund. Because nearly two thirds of Community spending has been absorbed by the operations of the CAP-particularly the buying and storing of surplus produce at relatively high prices and occasional subsequent sale in world markets at lower prices--no other Community policy has been the subject of greater scrutiny and criticism. The widely held perception that the CAP's intervention mechanisms have given rise to distortions and inefficiencies in resource allocation has tended to dominate public discussion of the common market and has frequently cast a shadow over many of the Community's other accomplishments. Indeed, in the minds of some critics the common market has become synonymous with the implementation of an agricultural policy which stimulates overproduction without any bearing on market realities.

The achievements of the CAP and its overall efficiency need to be examined against its original objectives and within the context of the EEC's common trade policies. To begin with, the CAP did lead to the stabilization of markets. The price intervention mechanism resulted in agricultural prices within the Community being more stable over time than other prices and more stable than prices in the world markets. Support buying and stock-adjustments have likewise compensated for supply and demand fluctuations. The CAP also contributed to greater selfsufficiency; whereas in 1960 the Six were self-sufficient in only four out of ten key agricultural commodities, by the early 1980 s the number had risen to nine. Agricultural productivity has likewise increased rapidly, leading to a widening gap between the rates of growth of production and consumption. The price intervention mechanism, however, has prevented necessary price adjustments and as a result surpluses have continued to rise. To the extent that CAP prices have tended to be above those prevailing in the world markets, the CAP's original goal of securing "reasonable" prices for consumers has not been met.

Other criticisms leveled against the CAP include: (1) that it is regressive in nature 
since, by artificially raising the price of food--to support farmers' incomes--it undermines the welfare of the poor among whom the share of expenditure on food is the highest; and (2) that the emphasis on self-sufficiency may have had an adverse impact on nonmember country producers by restricting access to the market; hence the Treaty's requirement that Community policy should contribute to the harmonious development of world trade may have been violated. Furthermore, the monetary compensatory amounts continue to exist despite the fact that the EMS has re-established a large measure of exchange rate stability.

The open-ended nature of the CAP's price support system has in recent years put increasing strains on the Community budget and has led to widespread calls for reform. At the heart of these proposals is the notion that price policy must reflect prevailing market conditions.

\section{Other common policies}

There are a number of other areas in which the Community has attempted to establish common policies and where progress has been considerably more limited. The Treaties called for the creation of a transport policy on the grounds that the emergence of more efficient methods of transporting goods between states could have trade-creating effects similar to those associated with the process of tariff reduction. But unlike agriculture, the Treaties left to the Commission the working out of the policy's objectives and the mechanics of implementation. Partly because the transport sector has been one of the most regulated within the Community, some of the Commission's original proposals-such as the need to create "competition of the widest scope" in the provision of transport services -did not receive the requisite level of political support.

A common energy policy was also thought to be an important Community objective. Differing national policies with regard to energy could give rise to distortions of competition or different approaches to the problem of dependence on imported sources of supply. Progress on this front has been limited for a number of reasons. Jurisdiction over energy matters has been divided, with the ECSC having responsibility over coal, Euroatom over nuclear power, and the EEC over oil, hydro-power, gas, and electricity. As in the case of transport the Treaties did not contain a timetable for the implementation of energy policy. National self-interestparticularly after the first oil shock-and heavy government intervention in the energy sector were further factors undermining the development of a viable common energy policy.
The completion of the internal market presupposes the implementation of a significant number of common policy measures affecting the agricultural, transport, and energy sectors. The internal market may thus act as the catalyst which will trigger further progress in the development of the EC's common policies.

\section{Prospects}

The Community's first 30 years may best be characterized as a series of achievements tempered by setbacks, and innovations in the wake of stagnation. The member states' commitment to integration and increased cooperation has coexisted with a reluctance, stemming from a desire to safeguard national interests, to transfer sovereignty to the Community institutions. The extent and the speed of progress has thus been largely determined by the relative strength of these two forces. Overly ambitious initiativesmuch like those that preceded the creation of the EEC-have been discouraged and ways have been found to keep the pace of change attuned to domestic political realities. The unanimity rule adopted in 1966, which effectively gave members veto power over Community decisions on the grounds that they might wish to defend "vital interests," is a good example of the latter force gaining the upper hand. In time it led to segmentation in the decision-making process, weakening the chances for consistency between different policies.

In spite of these setbacks, the 1980s have seen significant progress in a number of key areas. The EMS has succeeded in creating a zone of exchange rate stability through a greater coordination of financial policies and has led to the increasing recognition that such coordination will probably have to be brought under the control of a European central banking system. The Council's 1985 call on the Commission to "draw up a detailed programme with a specific timetable to achieve a single large market by 1992 " is further evidence of a renewed commitment to the accomplishment of the Treaties' original objectives.

But perhaps the most recent significant development-and one that is likely to have a profound influence upon the evolution of the Community in coming years-is the 1987 unanimous ratification by the member states of the Single European Act, an amendment of the Treaties of Rome. In addition to providing for the completion of the internal market, by restricting the rights of members to veto decisions in many key areas, particularly those pertaining to the elimination of barriers to the free flow of goods, services, labor, and capital, the Single European Act provides for a significant streamlining of the decision-making process. It is the legal instrument which will permit the speedy implementation of the legislative agenda set out for the completion of the internal market. The Act also brings under the jurisdiction of the Treaties new fields of concern-for example, the environment-and sets up a permanent Secretariat for political cooperation on foreign policy matters. Furthermore, it recognizes the competence of the Community in the area of monetary policy and enhances the consultative rights of the European Parliament.

Underlying these important policy and institutional developments is an increasing degree of popular support for the ideals which gave rise to the creation of the European Community. EUROPE 2000, a comprehensive opinion poll carried out by the Commission on the occasion of the thirtieth anniversary of the Treaties of Rome to assess European citizens' attitudes about "Europe," showed, among other things, that two out of three EEC citizens are in favor of the Community developing into a "United States of Europe" within the next 20 years and that nearly 60 percent would entrust a European supranational authority with responsibility over economic policy, foreign affairs, and defense within the same period. This is an extraordinary statistic that indicates a marked shift not only in economic attitudes but in psychological reflexes between generations which appear to be moving from an unquestioning faith in national sovereignty to a searching belief in more comprehensive loyalties. Against the background of several centuries of hostile nationalism and conflict, the results of this survey underscore the enormous changes that have taken place in the last four decades in the attitudes of the average European citizen, changes which augur well for the future of the Community.

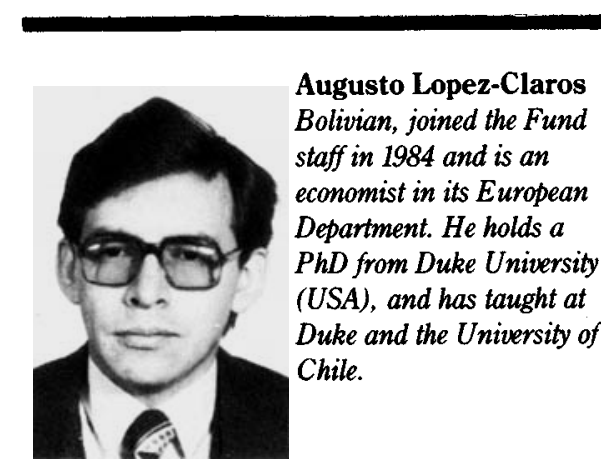




\title{
1. \\ Managing the Budget
}

The complexities of the US budgetary process explained

\author{
A. Premchand
}

$T_{1}$ he basic objectives of government budgeting, as they have evolved, are (1) to relate expenditure decisions to specified policy objectives and to existing and future resources; (2) to relate all major decisions to the state of the national economy; (3) to ensure efficiency and effectiveness in the implementation of government programs; and (4) to facilitate legislative control over the various phases of the budgetary process. The administrative process intended to convert these objectives into day-to-day operations operates within a political context. In recent years considerable publicity has been given to the budgetary situation of the United States, in particular the efforts to reduce-and eliminate--the deficit. However, the unique and complex US budgetary process, and the difficulties of effecting major changes, are often not clearly understood. This article seeks to provide an overview of the budgetary framework and process in the United States.

\section{A little history}

During the early years of the working of the Constitution, particularly after 1791, the US Congress showed the same attitude as the legislature in Britain and made efforts to gain control over the Executive branch of government through the device of specific appropriations of funds for purposes approved by Congress. This period witnessed the ascendency of the Congress over the Executive in the control of the budget. Within the Executive, the Treasury Department was assigned the task of transmitting the budget estimates to Congress, and the President had no responsibility for the budget. Congress, for its part, was more anxious to gain control over the Executive and had little interest in securing economy in expenditure. This situation continued practically up to 1912 when the whole issue was comprehensively reviewed by the Taft Commission which recommended placing responsibility for the budget in the President's office. But the implementation of this recommendation had to await the end of the First World War. The war period itself witnessed a slight relaxation in the Congressional control in that greater flexibility was given to the Executive to meet war exigencies. In 1921, with the passage of the Budget and Accounting Act, a Bureau of the Budget was established in the Executive, and was entrusted the task of preparing an annual budget. Passage of the 1921 Act was facilitated by the belief that centralization of the primary responsibility in the Executive would lead to expenditure and tax reductions from the high levels experienced during the war.

The implementation of the new procedures ushered in as part of the 1921 Act involved the establishment of several Congressional committees to approve, modify, or disapprove the President's proposals; to authorize and appropriate funds; to oversee departmental activities; and to raise taxes or incur debt. Each committee developed, in due course, its own domain and, as a consequence, sectional interests emerged as major political phenomena. The President had to rely on his powers of persuasion or ability to reach political agreement to ensure availability of funds. The procedures for budget approval also increased in complexity and the achievement of the goals of economy and efficiency continued to be elusive. Indeed, the whole process became so entropic that the late Professor Arthur Smithies of Harvard, reviewing the situation in 1955 , thought that it was miraculous that the process worked as well as it did, and attributed it to the 'triumph of the wisdom of individuals over defective organization.'

\section{Recent developments}

The problems arising from the excessive fragmentation of jurisdiction among the Congressional committees led to friction among them. Often policy purposes were lost in attention to minutiae, and isolated actions by the committees did not add up to coherent strategies. Appropriation bills were also not completed in time, and more significantly by the early $1970 \mathrm{~s}$, there was a considerable increase in 'backdoor' spending or resort to methods to circumvent the appropriation process through the enactment of laws mandating federal payments, and granting of authority to enter into obligations, prior to appropriations. Further, in the early 1970s, there were Presidential impoundments of voted funds with a view to containing budget deficits. As the legislature became more vulnerable to budgetary stress, the systems and procedures of budget making in the Congress came to be examined more closely. The result of this scrutiny was the enactment of the Congressional Budget and Impoundment Control Act of 1974. As a part of the implementation of this Act, new institutions were established and improved procedures 
Appropriation: Authority that permits government agencies to incur obligations and to make payments for purposes specified.

Authorization: A measure enacted by the Congress providing the legal base for the operation of an agency or a program; it is a prerequisite for appropriations.

Balanced Budget and Emergency Deficit Control Act of 1985: Also known as 'Gramm-RudmanHollings' Act, it establishes maximum deficit amounts for fiscal years 1986 to 1991.

Base-Line Projections: Projections of future revenues and expenditures under current law or policy.

Budget Authority: Authority provided by law to enter into obligations leading to outlays. This includes appropriations, authority to borrow, and authority to enter into contracts in advance of an appropriation.

Budget Resolution: A resolution passed by both Houses of the Congress setting out aggregate outlays, revenues, loans, loan guarantees, etc. This does not require the President's signature. The spending and credit aggregates are distributed among functional categories.

Credit Budget: This covers proposed direct loan obligations and guaranteed loan commitments.

Entitlement: This refers to programs operating under law to make payments for which the budget authority is not provided in advance by appropriation acts.

Functional: This refers to the 21 categories into which spending Category: and credit are divided in a budget resolution for analytical purposes.

Margin: Difference between receipts and outlays: margin is negative when there is a deficit, positive in the context of a surplus, and zero when there is a balance.

Of-Budget: This refers to programs and entities that are excluded from the budget (e.g., pension funds).

Outlays: Payments made normally in the form of checks issued or cash disbursed.

Beconciliation: This refers to a provision in the concurrent resolution on the budget that calls on congressional committees to recommend legislative changes that increase receipts or reduce outlays to be in line with the levels set in the budget resolution.
Government agencies submit their budget request to the Office of Management and Budget (OMB) by early September. The federal agencies are expected to follow a three-track approach to budgeting-the implementation of the current fiscal year's budget, the procurement of Congressional approval of their budgets for the next fiscal year, and preparation of the budget for the year after that. To illustrate, in April 1987 federal departments would be working on the execution of the 1986-87 budget, processing the approval of the budget for 1987-88, and compiling initial estimates for the 1988-89 budget (i.e., the budget that will be transmitted by the President to the Congress in January 1988).

The estimates so furnished by the agencies are reviewed by the OMB and, after necessary revisions, are consolidated into the President's budget and submitted to the Congress in January of the following year. Two features of this process merit particular attention. First, the budget is formulated in the context of a multiyear budget planning system, and the estimates cover the four years following the budget year. Second, the estimates also show the budget authority and outlays needed to maintain government services and activity without any change in policy and thus reveal to the Congressional committees the magnitude of discretionary spending.

The budget is then considered by the Congress and eventually modified or approved in a different form. A first step in government spending is authorization of funds (see box). The Congress, however, votes on the budget authority and not on the level of outlays. (Chart 2 shows the relationship between budgetary authority and outlay.) In many cases, authorizations may be available for a specified period or without any limitations. Appropriations are the main form of budget authority provided by the Congress and it is these that permit the agencies to incur obligations.

As a first step in the Congressional process, the President's budget is subjected to hearings by the two budget committees in the House of Representatives and in the Senate. The committees also receive the analysis of the CBO by February 15. This analysis pays particular attention to the economic assumptions of the budget and to the baseline projections. The next step is the receipt of the recommendations of all standing committees (see Chart 1) of both the House and the Senate concerning the new budget authority and outlays for activities under their jurisdiction. This is followed by the passage of a budget resolution by April 15. The resolution sets out the budget authority and outlays in terms of the major aggregates and 


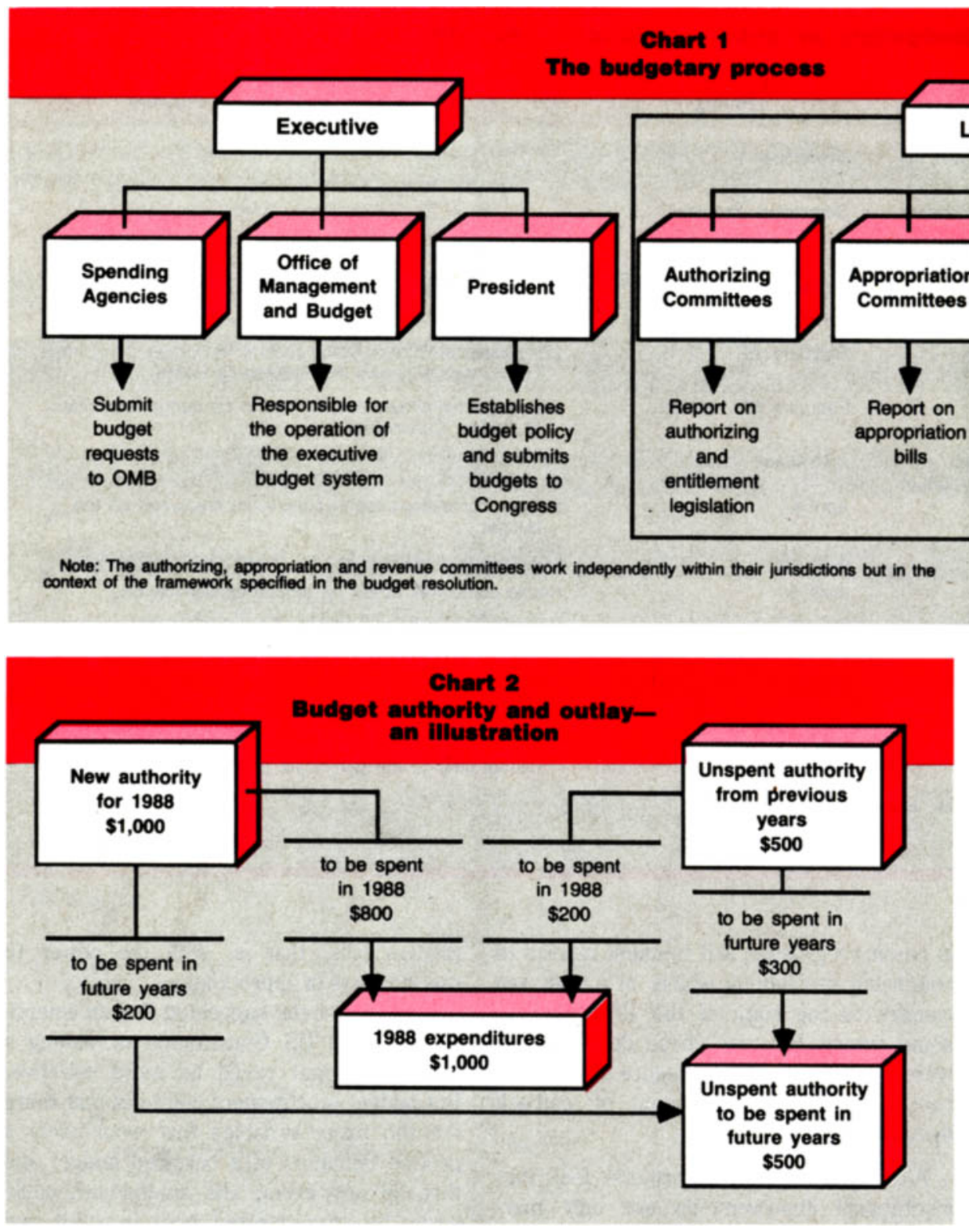

provides guidance to the Congress in its subsequent revenue and spending decisions. Budget authority and outlays indicated in the resolution are considered as ceilings and the estimated revenues as a binding floor.

The appropriation process is initiated in the light of the budget resolution. Traditionally, appropriation bills originate in the House of Representatives and the appropriation committees of the two Houses are structured into subcommittees on the lines of federal government departments to oversee their funding needs. After these needs are approved by the House, they are sent to the Senate which undertakes a similar review. In cases of disagreement, a conference committee comprising members of both chambers is organized to resolve differences. The report of the conference committee is then approved, first in the House and then in the Senate, and thereafter submitted to the President for his approval or veto.
A major step in the Congressional action is the reconciliation process. The purpose of this is to require all Congressional committees to implement the decisions embodied in the budget resolution in regard to tax and spending matters. This process may involve more than one committee. Action on reconciliation and appropriation is to be completed by end-June of each year. If, however, these various actions are not completed by the beginning of the fiscal year (i.e., by October 1), Congress enacts a 'continuing resolution' under which funds are provided to defray government expenses.

A more recent addition to the process is the requirement under the Gramm-RudmanHollings Act to adhere to a designated deficit target or the total margin which covers both budget and off-budget items (see box). If, however, the target is unlikely to be met, the Act provides that budgetary resources may be sequestered by reducing outlays. The
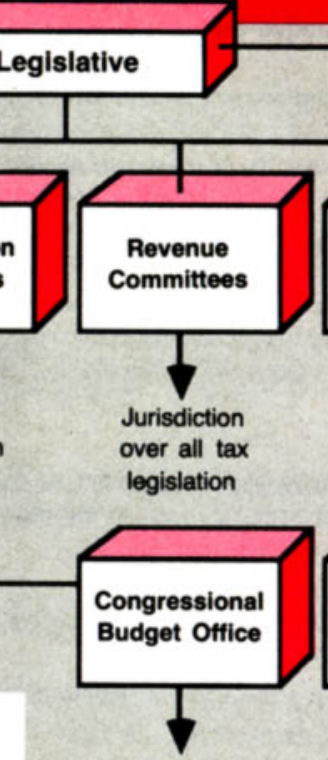

Issues reports on budget and economy including 5-year budget projections

Reports on Audit operations of federal agencies

(Although the GAO no longer plays a statutory role in terms of the Balanced

Budget Act of 1985 ,

it provides analyses

of budget reductions in response to congressional requests.)

need for this reduction is determined in the light of a joint assessment by $\mathrm{OMB}$ and $\mathrm{CBO}$, and Congressional consideration thereof.

The budget, after its approval by the President, becomes the basis for the release of budget authority and resources through an apportionment system, administered by the OMB, in terms of defined periods and categories of activities. If more resources are needed in the course of the year, supplemental requests are considered by the Congress. Within the Executive branch, certain deferrals (i.e., temporary withholding of budgetary authority) or rescissions may be undertaken in certain contingencies. These must be reported to the Congress which can, however, overturn them and restore funds to the agencies.

\section{The system at work}

The objectives of the 1974 and 1985 Acts were to streamline and bring greater coherence, discipline, and economic context to budgetary procedures. This is no mean task given the various political pressures at work and the lengthy budgetary calendar. This calendar has many steps. At each step there is considerable uncertainty about the eventual 


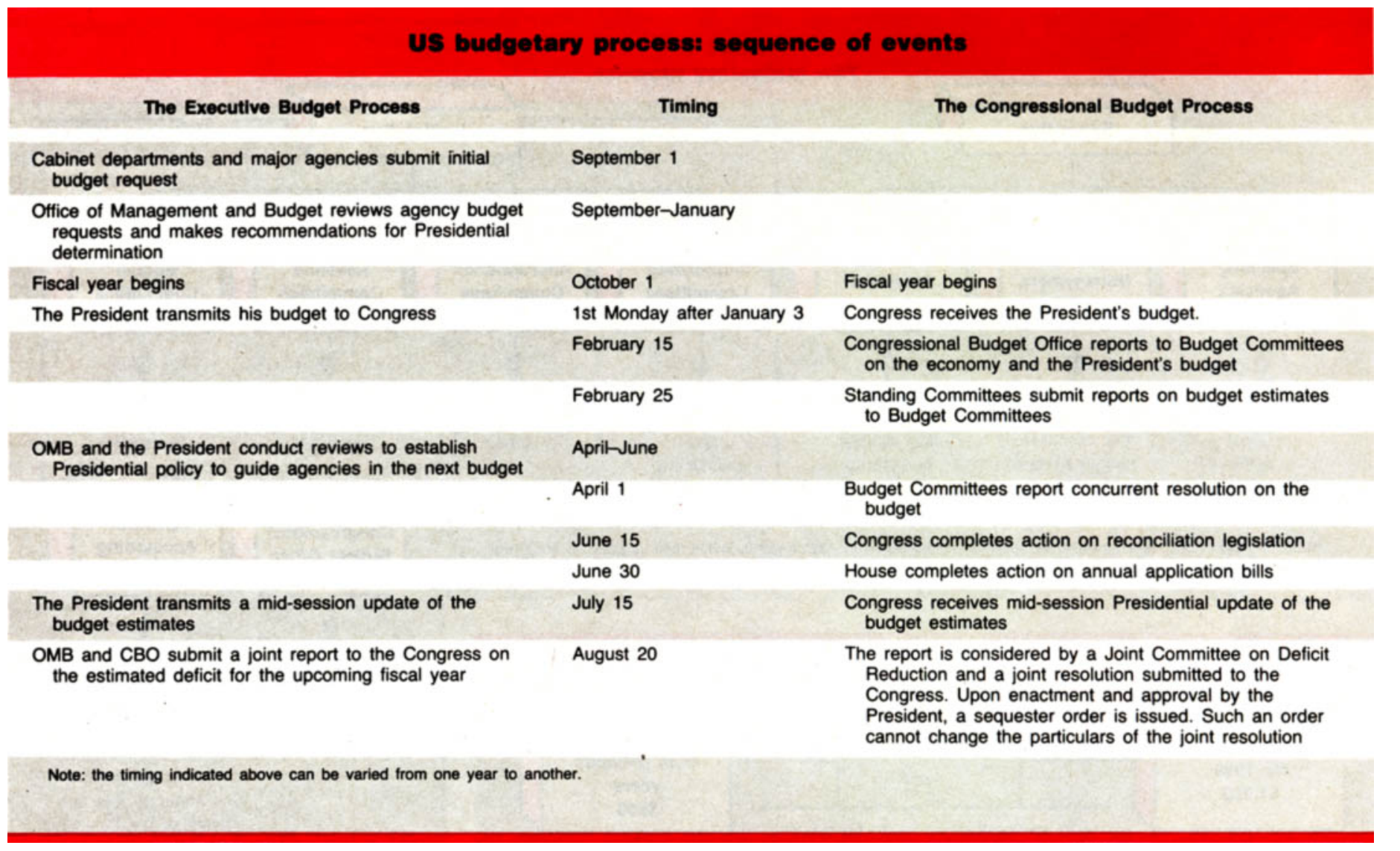

outcome. The determination of fiscal aggregates, including the magnitude of deficits, is not easy and the political decisionmakers have the difficult task of matching thought and action while seeking to ensure that what is decided is not only feasible but offers a coherent policy for the economy.

Legislative decisionmaking on financial matters needs good policy analysis. While such analysis is available from the CBO and the staff of the Congressional committees, it is also true that in the final analysis the budget inevitably reflects the political choices of the majority. These views are shaped by a combination of political philosophy, social priorities, pragmatism, and what is perceived to be the need of the hour. Members of the legislature are often impelled by local or regional considerations which lead to higher expenditures; these have then to be balanced by broader, national, considerations.

Both the 1974 and 1985 Acts testify to the desire of Congress to improve its operational procedures. In addition, the 1974 Act had a major role in arranging the convergence of revenue and expenditure budgets, in developing the credit budget, and in expanding the base of fiscal information. Further, the reconciliation procedures enabled the legislature to assert the role of the budget committees and to enact sizable cutbacks. On the other hand, there were major delays in passing legislation and frequent resorts to continuing resolutions which, in a way, ran counter to the spirit of the 1974 Act. To some extent, however, these developments were exacerbated by the absence of a political consensus in an environment of 'cutback management.'

Although some policymakers feel that institutional improvements are only marginally relevant to existing fiscal dilemmas, others are of the view that there is considerable room for strengthening the budget process. An important issue, however, is not so much the identification of the problem areas as much as the bewildering array of options.

The proposals that have been made for improvement cover both the Congressional and Executive operations, as well as enactment of new laws. As regards the former, suggestions include the introduction of a biennial budget which, while enabling a longer timetable, would be in conformity with the tenure of the members of the House of Representatives (who are elected for twoyear terms), and combining the Appropriation and Budget Committees of the Houses. On the Executive side, it has been argued that in addition to the available options of deferral and rescissions, the President should also be endowed with a 'line-item' veto of Appro- priation bills, that is, with the power to rescind parts of appropriations.

It has also been suggested that an amendment to the US Constitution mandating a balanced budget would be more effective. But budget practitioners point out that there are too many variables that would defy a precise definition of a balanced budget and that in any event, the amendment could easily be circumvented both in spirit and word. Moreover, the Gramm-RudmanHollings Act is to be seen as an effort at mandating the size of permissible fiscal deficits.

The very fact that these avenues are being explored is an indication of the awareness of the problems and the perceived need for further reform.

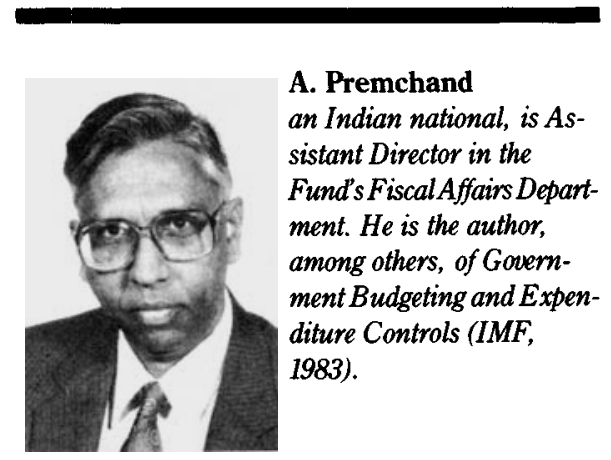




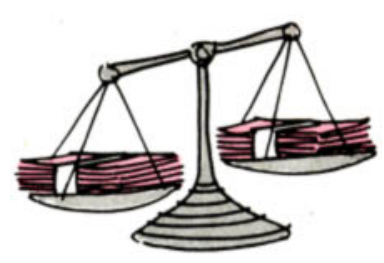

\title{
Why the World Current Account Does Not Balance
}

\author{
Shuja Nawaz \\ Managing Editor
}

$T_{t}$ balance in economics is analogous to Newton's Third Law of Motion in physics. For every surplus on a national current account there is, in principle, an equal deficit somewhere in the world, so that the world current account must sum to zero, with each deficit matched by an offsetting surplus. In other words, the amounts paid by intemational purchasers of goods and services should be matched, if all the bookkeeping is correct, by the receipts shown by the sellers of those goods and services. Yet, for the past decade or so, the global current account has shown a growing discrepancy, particularly in the accounts maintained by the International Monetary Fund. From a rough balance in the early 1970 s emerged an imbalance of about $\$ 20$ billion by 1978 , increasing more than fivefold by 1982 to $\$ 109$ billion, before gradually declining to $\$ 56$ billion in 1986 (see table).

The growth and persistence of the discrepancy indicated that either the deficits of some countries were being overstated or the surpluses of others were being understated. In any case, the large size of the imbalance, relative to the recorded deficits of major regions of the world, gave rise to international concerns that it could lead to inappropriate policy actions.

To investigate the causes of this growing discrepancy so that it might be corrected, the Executive Directors of the Fund set up in 1984 a Working Party of international experts (including Fund staff) to examine, in particular, the investment income accounts and the role of offshore financial centers in the compilation of world current accounts. This Working Party, assisted by the staffs of the
Fund and the Organisation for Economic Co-operation and Development, completed its work in 1986 and presented a report in early 1987. This article draws upon that report to explain the problem and its causes.

\section{Why data matter}

In a global economy that relies on international trade of goods and services, national economic policy is based on an analysis of data on national and international transactions. A consistent set of accounts, along the lines of similar accounts maintained by other countries, allows a country to assess its economic performance, to conduct a mean-

\begin{tabular}{|c|c|c|c|c|c|c|c|c|}
\hline \multicolumn{9}{|c|}{$\begin{array}{l}\text { Summary of global payments balances on current account- } \\
\text { recorded and adjusted, 1979-86 } \\
\text { (In billions of US dollars) }\end{array}$} \\
\hline & 1979 & 1980 & 1981 & 1982 & 1983 & 1984 & 1985 & 1986 \\
\hline \multicolumn{9}{|l|}{ Industrial countries } \\
\hline Recorded & -23 & -62 & -20 & -22 & -22 & -62 & -54 & -9 \\
\hline Adjusted $^{1}$ & -27 & -55 & -6 & - & -9 & -44 & -40 & -2 \\
\hline \multicolumn{9}{|l|}{ Developing Countries } \\
\hline Recorded & 6 & 30 & -49 & -87 & -64 & -34 & -24 & -47 \\
\hline Adjusted & 4 & 33 & -40 & -70 & -54 & -21 & -12 & -44 \\
\hline \multicolumn{9}{|l|}{ Total } \\
\hline Recorded & -17 & -32 & -69 & -109 & -86 & -96 & -79 & -57 \\
\hline Adjusted & -22 & -19 & -42 & -63 & -58 & -58 & -44 & -39 \\
\hline Other countries & -3 & -2 & -3 & 3 & 3 & 4 & 3 & 1 \\
\hline International organizations & 2 & 3 & 3 & 3 & 3 & 4 & 5 & 5 \\
\hline Total, adjusted ${ }^{1}$ & -22 & -18 & -42 & -57 & -52 & -50 & -36 & -34 \\
\hline
\end{tabular}

Source: IMF, World Economic Outlook, Washington, DC, April 1987

- Indicates that the figure is zero or that the item does not exist.

Note: For 1979-84 adjustments are based on the Final Report of the Working Party on the Statistical Discrepancy in World Current Account Balances; for 1985-86, adjustments are based on preliminary Fund staff estimates. Includes adjustments for which no geographical breakdown is available. 
and assess the role and performance of individual countries or groups of countries (see box "IMF global statistics").

The emergence, in the early 1970s, of an unexplained discrepancy in the global current account balance highlighted the difficulty of making accurate analyses of global economic trends on the basis of incomplete information.

Similarly, incomplete information on the sources of imbalances affects the quality of multilateral surveillance over exchange rates of the major industrial countries, since an unexplained imbalance creates uncertainty about the accuracy of estimates of the current account of a country or countries. This, in turn, affects the analysis by Fund staff of both the imbalances and the underlying exchange rates, and undermines confidence in projections of world economic growth, such as those published in the Fund's World Economic Outlook. If major countries adopt deflationary policies to cope with their apparent balance of payments deficits, their actions may produce a global deflationary bias. The growing discrepancy suggests that the growth of global output over 1979-82 may have been understated by as much as one percentage point.

Further, capital flows and exchange rates can be influenced by expectations about changes in balance of payments, and the expectations may themselves be guided by perceived movements in the current account. An inaccurate estimate of the current account may lead a country to take inappropriate action, such as adopting a protectionist policy to counter an expected or growing deficit. For all these reasons, it is important to understand the origins of the global imbalance on the current account, and its implications for particular countries or groups of countries.

\section{Sources of the discrepancy}

Broadly speaking, major changes in the nature and speed of international financial transactions in the past decade have been at the root of the growing statistical gaps in the income sector of the global balance of payments accounts. Rapid changes in the technology for effecting transactions and transferring enormous amounts of money across national boundaries emerged in the wake of the liberalization of the international financial system and the closer integration of financial markets. Further, political and economic uncertainties in some countries meant that investment flows emanating from those countries were concealed by investors from domestic authorities.

Large-scale financing through traditional investment centers and newer offshore centers, using indirect channels (such as foreign

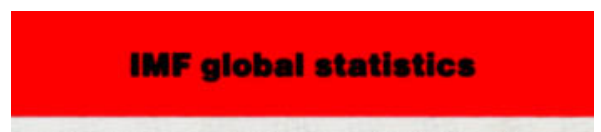

The Balance of Payments Statistics Yearbook of the Fund serves as the repository of data reported to the Fund by member countries. Part 1 of this Yearbook carries balance of payments statistics of individual countries as reported by them in accordance with the procedures and categories spelt out in the Fund's Manual for production of such statistics.

A separate volume, Part 2, summarizes the information from Part 1 and, based on further estimation and adjustment by Fund staff, presents regional and global balances. This is where the discrepancy in the global current account shows up.

subsidiaries of multinational banks and other financial institutions based in tax havens) complicate the process of recording and attributing capital flows to their countries of origin. These changes, coupled with the emergence of a growing service sector in international trade, made it well nigh impossible for national authorities to track and record all transactions involving their residents, or to make reasonably accurate estimates. Traditional merchandise trade has been recorded for very long periods, partly because it is often subject to duties or regulation, so that data on such transactions are relatively well established. They happen to balance out fairly well, for the world as a whole. Service transactions by their very nature are intangible and difficult to define and measure; they do not have a long tradition of statistical enumeration. There is now an international effort to improve these data.

Based on three comprehensive questionnaire surveys giving details of data reported by a broad cross section of national statistical agencies, detailed discussions with national compilers of balance of payments statistics, and intensive analysis of available data on international financial flows, world shipping, and unrequited transfers, the Working Party identified the main sources of the gap in the global current account.

Much of the discrepancy in global accounts resides in the failure of investment income accounts to capture transactions accurately. The emergence of a large body of "crossborder assets," or capital held in other countries, has been recognized by most debtor countries but not by creditors in their national accounts. High interest rates after 1979 that raised the return on these investments exacerbated the inconsistency in reporting of such assets. Over the period $1977-83$, for example, some $\$ 300$ billion in reported net inflows (excluding reinvested earnings from these investments) did not show up in the accounts of the countries of origin of these flows. An examination of individual types of investments and related income reveals the extent and nature of the discrepancy.

Direct investment income. This includes after-tax income from foreign affiliates of multinational companies, as reflected in tax accounts of creditor and host countriesincluding any undistributed profits. These earnings and other activities of multinational enterprises are difficult to trace given the complicated structures of these operations and lack of detailed and consistent information from country to country. Many countries have difficulty in collecting the necessary data from these enterprises. Even when data are available it is often difficult to allocate direct investment income geographically on a consistent basis because the entity that is the source of income may be owned through a multinational subsidiary based in a third country.

- Reinvested earnings. This component of income from direct investment includes portions of the net profits from overseas operations that are not declared as dividends to the home countries of investors. In 1983, some $\$ 13.9$ billion in reinvested earnings were reported by investing countries to the Fund, whereas only $\$ 4.4$ billion of debits were reported by countries where these investments had been made, leaving $\$ 9.9$ billion unaccounted for. The main problem is that many debtor (host) countries do not collect or calculate data on such reinvested earnings, whereas the major creditor countries collect and report these credits in their accounts.

- Other direct investment income. This covers dividends, branch profits, and interest paid by affiliates to the parent company. The main source of the very large discrepancy in the reporting of this item was inadequate and inconsistent reporting of such income. The information needed must come from the enterprises concerned, and, of course, the operations of multinationals are very complex and measurement and geographic allocation of source of income is somewhat arbitrary. The Working Party has suggested that the statisticians in creditor and host countries cooperate to achieve a better matching of credits and debits. There was an excess of debits of some $\$ 11.5$ billion in this account in 1983, with host countries debiting some $\$ 33.8$ billion in such payments while investing countries reported receipts of only $\$ 22.3$ billion. The Working Party was able to identify the specific origins of about half of the discrepancy; Fund staff will make further efforts to reduce the discrepancy. 
Portfolio investment income. This covers interest and dividend payments to and from banks and other financial institutions, including interest and dividends on marketable securities and other financial instruments, such as mortgages and suppliers' credits.

A very large and rapidly growing net debit is shown when the global accounts are aggregated for this account. The Working Party traced the origins of most of this discrepancy to the fact, mentioned above, that over the years inflows of capital reported by countries receiving funds have been much larger than was recorded in the accounts of countries where the funds originated. Thus, the debtor countries recognize these growing liabilities, and are able to enter in their accounts a reasonably full record of the interest payable to the nonresident owners, whereas the countries where the owners reside have no record of the accumulating capital and therefore do not record a comparable amount of income credit.

The Working Party showed that most of the inconsistency in reporting can be identified and eliminated by using the cross-border banking data collected and published by the Fund in Intermational Financial Statistics as a check on the income flows of individual countries. In addition to helping to eliminate the global discrepancy, the use of the detailed geographic data in the banking statistics allows an estimate of the geographic distribution of the missing income receipts.

This is the fastest growing and currently the largest item of discrepancy in the current account balance. It accounted for 43 percent of the gap in reporting of income from services in 1984. Some $\$ 42$ billion more of portfolio investment income was debited in 1984 than showed up in the credits reported for that year by investing countries.

Shipping and other transportation. Intemational shipping has an intricate network of ownership and operating responsibility. Moreover, a number of countries whose residents operate large fleets do not report freight earnings or fleet expenditures to the Fund. Consequently, a substantial part of world freight earnings and ships expenditures are not covered in the global accounts. The Working Party traced most of the problem to the incomplete coverage, together with some specific cases of incorrect reporting. Many countries also understate their earnings from port expenditures (a major portion of "other transportation"). While the global discrepancy in the shipping and transportation accounts is quite large--a net debit of over $\$ 30$ billion-it is relatively steady, and therefore is less likely to lead to errors in the analysis of current trends.
Unrequited official and private transfers. These are entries in the balance of payments covering provision of goods, services, or cash by one party to another without any obligation for repayment. The main types of official transfers are development assistance, direct and indirect, including, among other things, debt relief and payments to international organizations. Private transfers cover a range of activities, most notably remittances by migrant workers.

For official transfers, donor countries showed some $\$ 14.2$ billion more in debits in 1984 than was evident in the $\$ 35.2$ billion of inflows indicated by recipient countries. The Working Party located part of the origins of this discrepancy-including the fact that data for international organizations were being left out-and has provided guidance for further analysis. Private transfers show an excess of $\$ 3.7$ billion reported by countries as credits in 1984 over debits of some $\$ 33.6$ billion reported by countries of origin of these flows.

Role of offshore centers. Traditionally, a small number of major centers, such as London, New York, Amsterdam, Zurich, and Paris, have been involved in the international movement of financial resources. With the opening up of the international financial marketplace, and in response to the demand for specialized services, many new centers opened up or expanded their operations during the past decade, making it even more difficult to follow and report accurately on all international financial flows. The major new offshore banking centers include the Netherlands Antilles, The Bahamas, Bahrain, the Cayman Islands, Hong Kong, Singapore, and Panama, accounting for a substantial share (20 percent) of foreign assets of banks that used international financial centers in 1985.

The growth of offshore banking centers was accompanied by the emergence of innovative financial instruments with considerable effect on accounting techniques. The newer instruments, together with the greater use of swaps and options, tend to obscure the ownership of assets as between residents and nonresidents--a crucial problem for international accounting. Moreover, the changes in banking practices have tended to move these instruments off banks' balance sheets; the nonbank creditors and debtors are much more difficult to reach as sources for the data on crossborder capital and income flows, thus complicating the job of national and international authorities in compiling full and accurate data on financial flows. The existence of the offshore centers adds another layer of difficulty in measuring flows, and encourages investors and their intermediaries to attempt to conceal their activities. Moreover, the growing use of interest rate and currency swaps, and floating rate notes has created a mercurial accounting situation; as highly specific and highly liquid new instruments emerge and change ownership rapidly, their trading becomes less susceptible to recording as between residents and nonresidents in balance of payments accounts.

\section{Removing the discrepancy}

As the Working Party examined the sources of discrepancy or the accounts that reflected most of the asymmetry in the global current account, it collected additional detailed data via questionnaires and located specific examples of erroneous reporting as well as more generalized sources of error. Corrections were suggested for individual variations and gaps partly by closer examination of bilateral national accounts, and suggestions were made for changes in methodology to be applied by all countries and the Fund. The adjustments made by the Working Party reduced the estimate of the global discrepancy from $\$ 109$ billion at its height in 1982 to $\$ 57$ billion, and in 1986 from a reported $\$ 56$ billion to some $\$ 33$ billion. Broadly speaking, the Working Party found that over time a more comprehensive and uniform application of flexible statistical techniques for compiling and reporting data to the Fund, rather than dependence on information from banks on foreign exchange dealings, would resolve many of the problems leading to the imbalance in the global current account. Nevertheless, the negative discrepancy in the global balance of payments data is still quite large and further effort will be required to reduce it.

Following the release of the Working Party's report to the Executive Directors of the Fund (see box on publication), efforts were begun to improve the collection and reporting of data on each of the items found to give rise to discrepancies in the global current account. An important part of this effort will be the updating and improvement of the Fund's Manual for balance of payments reporting, to take into account the innovations in the global financial marketplace and the difficulties identified in tracing transactions in various sectors. The techniques used by the Working Party are expected to provide guidance for the improvement of procedures both in the Fund and its member countries to collect and publish global financial statistics.

The Final Report of the Working Party on the Statistical Discrepancy in World Current Account Balances is published by the IMF. Copies may be ordered from Publications Services, IMF, Washington D.C. 20431 USA. 


\section{(4orld Bank Reorganization}

L in May 1987, the World Bank began to implement its first institution-wide internal reorganization since 1972 , the early period of Robert McNamara's presidency. The current President of the Bank, Barber B. Conable, who launched the reorganization, said that the purpose of the exercise was to make the World Bank more responsive and efficient in the face of new developmental realities. According to Mr. Conable, the Bank's organizational structure had not kept pace with the changing global environment.

As Mr. Conable has explained: "The opportunity to strengthen significantly the Bank's organizational responsiveness in delivering development assistance to its borrowers is the guiding purpose behind the reorganization and one which the new structure must serve."

The reorganization will clarify and strengthen the roles of the President and senior management in providing overall strategic and policy direction for the Bank. This will enable the President to provide effective leadership in five critical areas:

- Defining the Bank's short- and long-term strategic agenda.

- Deciding major institutional issues, while delegating day-to-day decisions to line managers.

- Ensuring that major issues receive adequate debate and analysis.

- Defining the Bank's management struc-

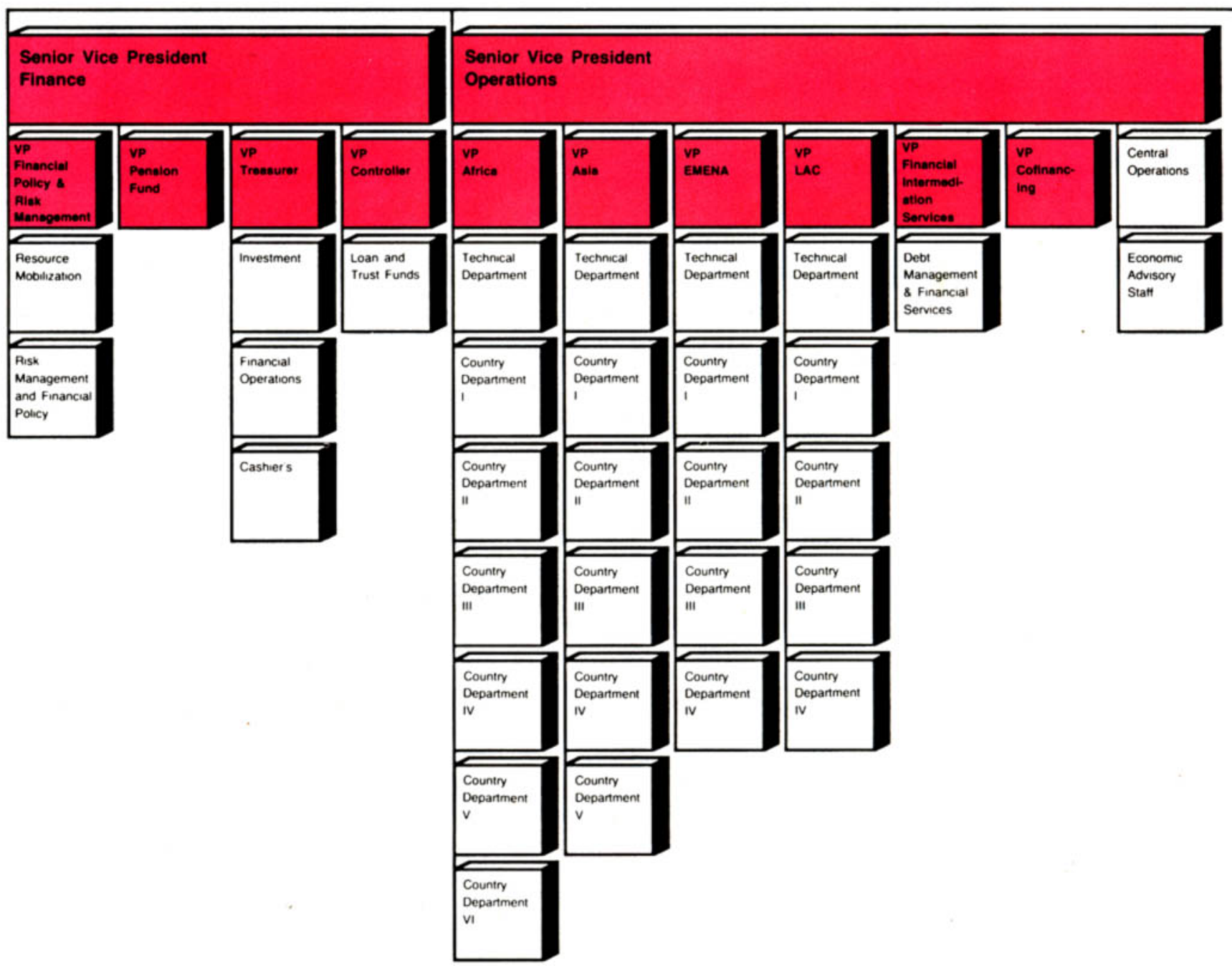


ture and making key appointments.

- Representing the Bank publicly and building support for the institution among its shareholder governments.
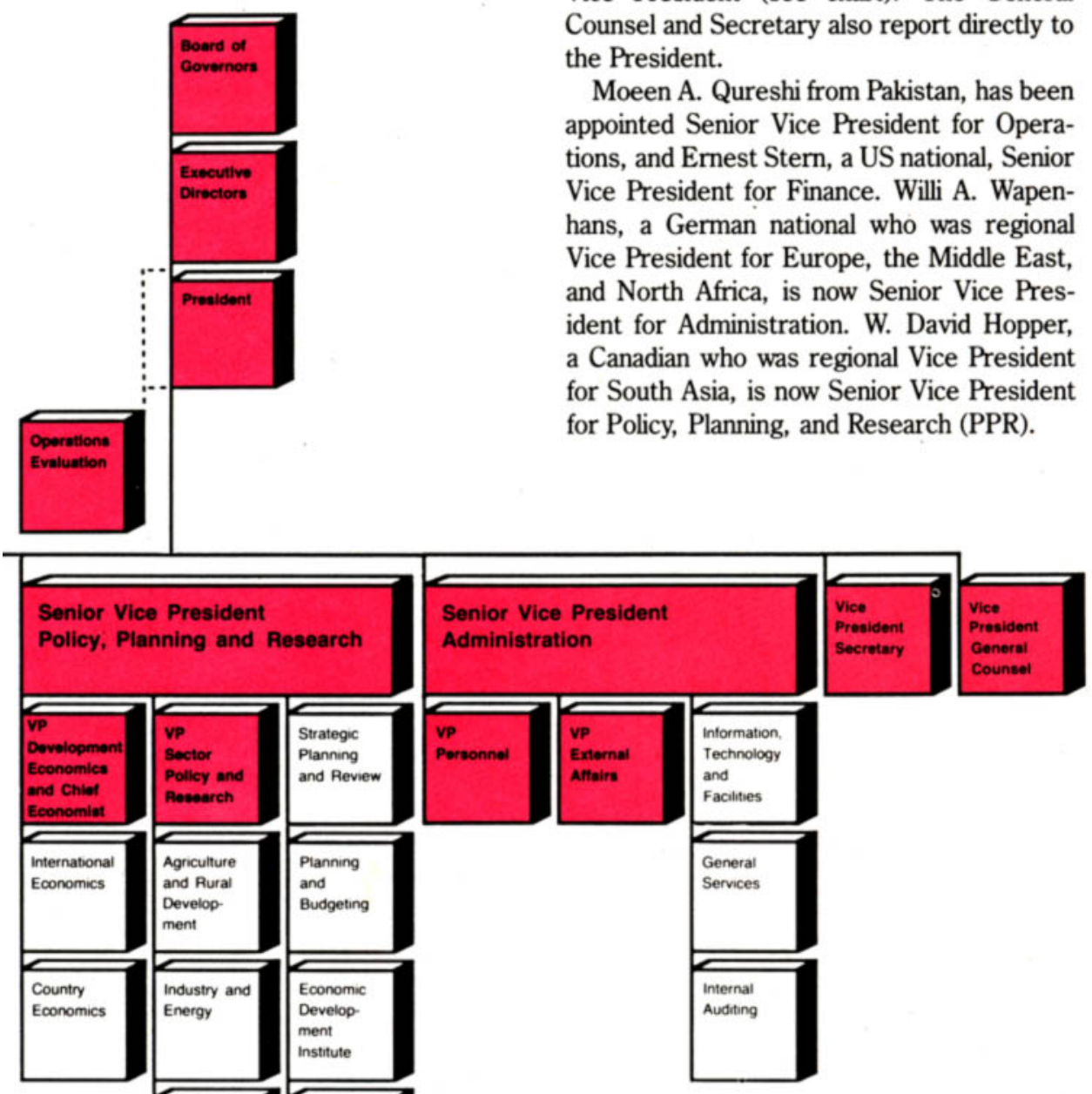

PPR is a new complex which combines the interrelated activities of research, policy formulation, strategic planning, and institutional budgeting that formerly were dispersed across the Bank. The reasons for this consolidation are to:

- Strengthen the Bank's capacity to provide intellectual leadership in the development field and translate the results of research and other analytical work into tangible benefits for the Bank's borrowers.
- Enhance the Bank's capacity to manage strategic issues by linking the policy and research functions with strategic planning and budgeting activities.

\section{Changes in operations}

The number of regions within the Operations complex has been reduced from six to four, each headed by a Vice President. The new regions are Africa; Asia; Europe, the Middle East, and North Africa (EMENA); and Latin America and the Caribbean (LAC). Each region is organized into country departments that combine the operational management functions previously divided between programs and projects departments. In addition, each region has a technical department that is organized into five functional divisions: trade and finance, agriculture, industry and energy, infrastructure operations, and environment. There are some regional variations in divisional structure.

Country department directors have been delegated broad authority, in an effort to reduce management layers and promote efficiency. Each country department's management structure is composed of a country operations division chief, division chiefs for each of the major sectors, and resident representatives.

In addition to the four regional Vice Presidents, there is a Vice President for cofinancing and a Vice President for financial intermediation services who integrate key financial assistance activities for borrowers.

\section{Other functions}

The changes in the Finance complex are relatively limited and relate to strengthening key financial functions and to clarifying accountability and control. Planning and budgeting has been relocated to PPR, and financial intermediation and debt management activities has been moved to the Operations complex.

To the extent possible, the Bank's support functions have been decentralized to the departments that use them. Certain support activities are now within the Administration complex. These include Personnel; External Affairs; Information, Technology, and Facilities (ITF); and General Services. The Internal Auditor also reports directly to the Senior Vice President for Administration but retains access to the President. 


\section{WORLD ECONOMY IN TRANSITION}

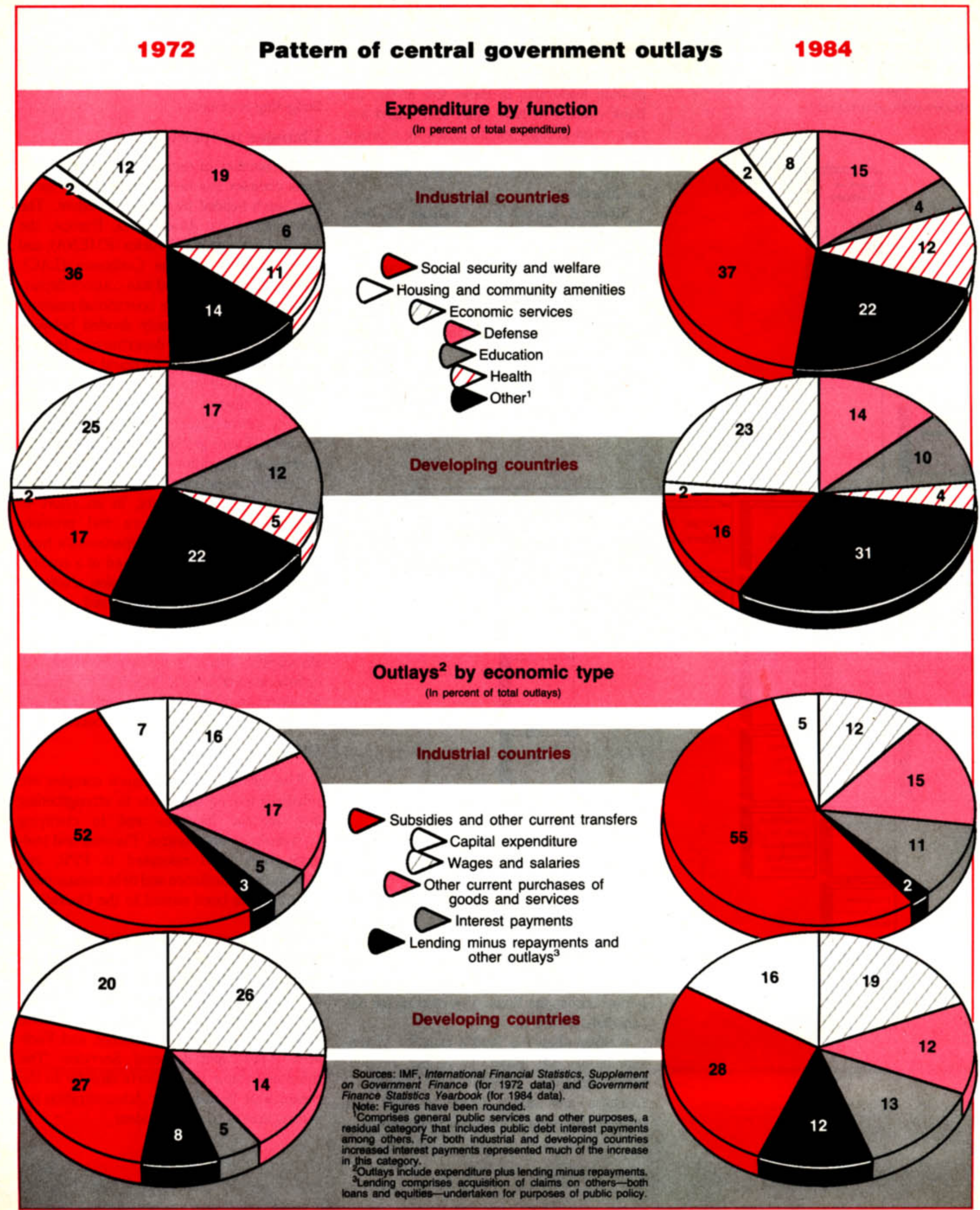


Inving Friedman

\section{Toward World Prosperity}

\section{Reshaping the Global Money System}

Lexington Books, Lexington, MA, USA, 1987, xiii + 317 pp., \$24.95.

This book reviews the performance of the international monetary system over the past two decades and proposes ways of improving its future performance. The analysis centers on the debt crisis of the early 1980 s and on proposals for restoring creditworthiness and economic growth in the affected countries, while creating institutional mechanisms for avoiding a repetition of the recent experience.

Friedman argues that the creditworthiness of the major developing borrowers in the 1970s was well established, based on their previous economic performance, domestic economic management, and debtservicing record. This creditworthiness was lost in the early 1980 s as a result of delays in undertaking needed adjustments, symptoms of which were overvalued exchange rates and capital flight; overreaction by commercial banks fueled by "loud, ill-informed public discussions;" and inad- equate official national and international assistance, owing partly, in Friedman's view, to the inadequacy of the Fund's resources.

The author characterizes the resulting crisis as essentially one of economic development. The central need for borrowing countries is new money, which requires restoration of creditworthiness, and this, he maintains, cannot be accomplished simply through austerity and debt restructuring. Borrowing countries must show evidence of modernization, growth, and improved export competitiveness; and their policies must be convincing to lenders. This process would be assisted by longerterm Fund programs, where conditionality would be the combined responsibility of the Fund and multilateral development banks; by more innovative bilateral assistance; and a better "early warning system" by the Fund and commercial lenders. Naturally, a more rapidly growing world economy would also facilitate restoration of creditworthiness.

The author's major proposals for strengthening the international monetary system include a supplementary financing scheme to cover unexpected falls in export prices, increases in interest rates and import prices, and cutbacks in capital inflows. He also proposes a new international lending institution, privately run but with participation by the multilateral development banks, to channel private resources into development lending. Also included are proposals that the resources and activities of multilateral development banks be expanded, with a greater use of guarantees; that the Fund's resources be greatly augmented; and that the Fund engage in countercyclical lending and exercise greater influence over the economic policies of major members. With such reforms in place, Friedman concludes, the international banks would perceive less risk in renewing voluntary new lending to heavily indebted developing countries.

Although at times prolix, this volume is full of wise reflections based on Friedman's extraordinarily wide experience in the Fund, the World Bank, and international banking. His proposals deserve serious attention.

Anthony Lanyi
Sebastian Edwards and Alexandra Cox Edwards

\section{Monetarism and Liberalization}

\section{The Chilean Experience}

Ballinger Publishing Company, Cambridge, MA, USA, 1987, xxi + 233 pp., $\$ 25$

This book provides a thorough, incisive, and very professional analysis of one of the most fascinating economic experiences of recent years--that of Chile during 1973-83. In that decade, Chile underwent one of the most radical changes in economic management in Latin America.

In the years prior to 1973 , the Chilean economy was characterized by extensive government intervention. In most markets, this resulted in major distortions that were accompanied by significant financial imbalances, eventually resulting in a sharp acceleration of inflation, a deterioration of the balance of payments, and low average rates of economic growth.

In the period under review, various areas of the Chilean economy were liberalized, the role of the private sector was enhanced, financial imbalances were reduced, exports increased, and the rate of inflation declined. Eventually and notwithstanding a worsening of Chile's terms of trade, the economy experienced a rapid expansion of output, and particularly of investment. However, this experiment in market liberalization unintentionally contributed to a major crisis in the early 1980 s that aggravated the impact of weakening export prices and the advent of the debt crisis. By 1983, Chile was left with a weakened private sector, low levels of savings, and an extremely high ratio of external debt to GDP, with the public sector having taken over most of the external debt obligations.

The Edwardses analyze developments of the period and discuss the policy stance that led to deteriorated economic conditions. They show a high degree of professionalism in their presentation, combining a pointed description of events and a lucid economic analysis of these events. The result is a book that will be an asset to readers keen on Chilean economic history and also to those interested in the application of general economic theory to the experience of developing countries.

The book reviews several aspects that were essential to the Chilean experiment. In particular, it discusses the stabilization policies that were pursued, first through a closed economy and then through an open economy and fixed exchange rate-management approach. In addition, the book reviews financial liberalization and its impact on interest and exchange rates; the process of privatization and deregulation; the liberalization of international trade; the effect of the experiment on unemployment and income distribution; and the sequencing of the liberalization reforms.

The authors conclude that the liberalization effort failed because of several major mistakes in economic management, identified as the lack of supervision of the banking system; the excessive concentration of economic power in a few economic groups; and the indexing of wages to past inflation. Other mistakes that they cite were the fixing of the exchange rate while the capital account was being liberalized; a mistaken sequence in liberalization of the external current account and capital account; and more fundamentally, a passive and somewhat rigid approach to macroeconomic management on the part of the economic authorities at the time.

The authors make it clear that the mistakes that affected economic policies did not preclude major advances in moder- 
nizing Chile and inducing it to become more integrated in the world economy, thereby creating the conditions for sustained growth. This structural reform eventually helped Chile to recover from the crisis of 1982-83. The book helps identify dangers inherent in any process of liberalization and points out the need for a consistent and credible set of policies to achieve that goal. While emphasizing the mistakes, the book also makes clear that they did not weaken the validity of the reformist goals that the Chilean experiment embodied.

Claudio Loser
Gordon A. Fletcher

\section{The Keynesian Revolution and Its Critics}

\section{Issues of Theory and Policy for the Monetary Production Economy}

St. Martin's Press, New York, USA, 1987, xxiii +348 pp., $\$ 35$.

It is a mark of great thinkers that they give rise to coteries of avid supporters and fervent opponents, including many who have never read a word of the master's works. Keynes, like Marx and Adam Smith, belongs to this elite category. Savior of liberal capitalism in his own mind and for one group of supporters, he was adopted as the respectable intellectual imprimatur for democratic socialism by another group, and has been cast as the corpus vile of all the wrong-headed policies of the past two decades by the growing ranks of his detractors. Keynes' seminal General Theory of Employment, Interest, and Money was published 50 years ago, in 1936. It inspired a new approach to economic analysis and macroeconomic policy that lasted well into the 1960s and 1970s, and continues to affect policy decisions under different labels. His principal message, that unimpeded market forces will not necessarily lead to full employment and stability, and that limited government intervention may be necessary to fill the gap in effective demand, has often been confused with an unquestioned support for all forms of central planning and government intervention in the economy. The general indictment against Keynes has been that, regardless of successes of Keynesian policies in the 1950s and 1960s--which, in any case, may have had more to do with the post-war recovery-the Keynesian approach was found to be sadly wanting when it came to the stagfiation of the 1970s.

The story of the Keynesian revolution has been told many times before, and the present volume adds little that is new. The earlier parts deal in detail with the minutiae of Keynesian theory on various matters (especially the debates with Robertson); to this reviewer they give the impression of lecture notes, augmented by text. The latter parts, in particular Chapter 23 on Keynesian policy in action, are far more interesting. Most of the actual policy examples are drawn from the United Kingdom, and there is relatively little on international economic policy and the role of Keynes in the Bretton Woods system. This book will be of most interest to the student of macroeconomics, though it is a convenient reprise of the various threads of the Keynesian revolution for all economists.

In the end, how important was the Keynesian revolution? Few would try to belittle his insights into theory and his legacy of a whole new framework for economic analysis. As regards Keynesian economics as a policy guide, the answer is less clear, and Fletcher betrays an oddly ambivalent attitude. He is a faithful disciple and adumbrates all the reasons why the prophet was right but the prescriptions no longer seem to work: his theories have been misapplied; economic circumstances have changed; the political pressures of a democracy proved too strong; there was a loss of control over economic policy; and so on. But if this is the case, in particular if the theory was right but "...the conditions which produced the need for the Keynesian revolution passed away," then was the Keynesian revolution but of transitory relevance, applicable only in the circumstances of the 1930s, and hence an anachronism now?

One would dearly like to know how Keynes would have reacted. He is buried, but it would be unwise to bury his economics.

Bahram Nowzad
Robert Klitgaard

\section{Elitism and Meritocracy in Devel- oping Countries}

\section{Selection Policies for Higher Education}

The Johns Hopkins University Press, Baltimore, 1986, $x i+190$ pp., $\$ 24.95$.

Why should economists be concerned about selection for higher education in developing countries? If countries do not choose their leaders from among their brightest citizens, it can have a grave effect on economic performance. By one estimate developing countries could improve their GNP per capita by 5 percent if they were to base leadership upon merit; by another estimate the economic benefit of meritocracy to developing countries would be three times greater than if OECD countries were to remove restrictions on imports of third world goods. Though hardly precise in results, both estimates are based on sound theory.
The theory suggests that certain elements of social selection, which provides social groups with the opportunity for leadership positions, are amenable to policy manipulation. There are basically three questions that can be addressed by policy makers: (1) whether a wide group of citizens enters school; (2) whether they stay in school; and (3) how they are selected to attend university. Klitgaard concentrates upon the third.

This is one of the first books to look at how developing countries might improve their selection mechanisms. Like many pioneering efforts, it is more heroic than polished. The author successfully addresses three areas of college testing dilemmas: policy (whether social groups are proportionally represented, the definition of merit etc.); technical (fairness in the phrasing of questions, achievement versus aptitude, multiple-choice versus openended testing format); and economic and managerial (who pays for the tests and how should they be given). Since much of the material has been drawn from previous work, subjects rarely flow easily from one to the next; gems of insight are nestled next to sections overflowing with regression formulae.

Nevertheless, the book has several virtues. It contains a fascinating discussion of "market-signaling" in higher education selection. For social reasons most testing in developing countries rewards those who perform well vis-a-vis other local contestants rather than reward them against their marginal productivity on an international scale. This can produce a higher education product of questionable quality. The wrong selection mechanisms may also encourage people to overinvest (from the social point of view) on the basis of the market signal, diverting energy away from more productive activities. This is true where tests overemphasize recall rather than evaluative thinking, interpretation, and synthesis. 
The case examples from China, the Philippines, Indonesia, and Pakistan also demonstrate the incentives provided by the university selection policy. The policy exerts a powerful influence on the kinds of teaching likely to be found in classrooms; on the kinds of students likely to think it possible to advance socially; on the kinds of talent likely to be selected for future leadership; and on the kinds of leaders likely to be available to interpret international market conditions and to make economic policy.

This book is among the first of what may become a series of research and policy investigations on the academic selection process in developing countries. It bypasses the very popular liturgy of the 1960 s, which held that testing was a form of tyranny, a mechanism of the already privileged to perpetuate their social and economic status. In the intervening years we have seen what happens when, as in the case of China's Cultural Revolution (or, in a less extreme example, in Tanzania), selection into university is based not upon academic merit but on more subjective social and attitudinal criteria. We have also seen research results indicating substantial differences between industrial and nonindustrialized countries. Perhaps because of relatively great rewards associated with in-school learning, less-privileged students in developing countries perform academically almost as well as contestants from socially privileged backgrounds from within the same country. This book accurately represents a number of conclusions relevant to selection policy: (1) the upper range of any normal distribution of talent constitutes an elite which countries must identify; (2) if well-designed, testing can be more fair and more efficient than are social and attitudinal criteria; and (3) testing can create either very positive or very negative incentives, both within and well beyond the school system.

The future prospects of developing economies will be determined to a large extent by the talent of their leadership. That, in turn, will be powerfully influenced by the degree to which they are selected for higher education on the basis of merit. This book represents a good start toward giving the selection mechanism the attention it deserves. Stephen Heyneman
Khushi M. Khan (editor)

\section{Multinationals of the South}

\section{New Actors in the International Eco- nomy}

St. Martin's Press, New York, 1986, 261 pp., $\$ 29.95$

A.E. Safarian and Gilles Y. Bertin (editors)

\section{Multinationals, Governments and International Technology Transfer}

St. Martin's Press, New York, 1987, 223 pp., \$37.50.

The pace of writings on the multinational corporation has slowed markedly during the 1980s. In part, this is because the subject has matured, and there is something of a consensus on why multinational corporations exist, how they operate, and what policies should be adopted to deal with them. As governments have gained confidence to flex their regulatory muscles, their fear of domination by multinationals has diminished. On the contrary, the onset of debt problems and the greater need for advanced technologies has led many governments to regard multinational corporations with open arms or, at least, cautious welcome. The era of exciting polemics has ended.

Current literature tends more to make marginal additions to old themes or to examine some new manifestation to the complex multinational phenomenon. The books under review provide an example of each. Both are conference proceedings. The Safarian-Bertin volume goes over the well-trodden field of multinational corporations and technology transfer, with the slight variation that it concentrates on Canada and France (rather than the United States or the United Kingdom, the traditional beat of the analysts). The Khan volume adds to the new and growing body of literature on developing country multinationals. It has no particular country focus, but surprisingly neglects Latin America.

Both volumes have interesting features, though they display the inevitable unevenness that plagues conference publications. The Safarian-Bertin volume is generally of better quality, with short, well-written papers: some provide competent reviews of recent research in their chosen fields, others provide interesting new data. The most valuable were those by Bernard Bonin, Gilles Bertin, and D. G. McFetridge who examined the role of multinational corporations in different forms of technology transfer. None reaches startling conclusions, but they confirm that multinational corporations prefer direct investment to transfer valuable proprietary technology, and that they are increasingly flexible in their strategies to transfer other forms of knowledge. There is also an interesting paper by Alan Rugman on the competitive advantages of Canadian multinational corporations. The author argues that these competitive advantages lie in mature, resource-based activities rather than in advanced research and development. Melvyn Fuss and Leonard Waverman offer a very stimulating analysis of Japan's competitive edge in auto production and debunk a number of common beliefs about the size of the Japanese productivity advantage.

The Khan volume has some good papers as well. The best ones are by John Dunning, on the "investment development cycle," and by Louis Wells, summarizing his pioneer research on developing country multinational corporations. Dunning brings out clearly the evolutionary nature of factors that determine international investment. The rise of multinationals in developing countries is clearly a manifestation of the process of technological and organizational learning on the part of industrializing developing countries, an aspect that Wells recognizes but downplays.

More attention should have been paid to the new breed of multinational corporations in developing countries that are competing head-to-head with established developed country firms in highly sophisticated industries. An example can be seen in the Korean firm, Samsung, which assembles its videocassette recorders and color televisions in the United States. As it is, too many of the papers in the Khan volume accept the rather static conventional wisdom on developing country multinationals: their competitive edge lies in mature, undifferentiated products where price competition is predominant, and their technological strength lies in down-scaled, labor-intensive facilities. While it is true that there are many corporations of this sort, there are a large number which are, apart from their size and spread, practically indistinguishable from conventional multinational corporations.

There is a tendency in many papers in the Khan volume to treat developing country multinational corporations as a vehicle for South-South cooperation and collective self-reliance. The time for such naive analysis is past. It does the subject of developing country multinational corporations a disservice to force their analysis into this mold.

Sanjaya Lall 
Frances Stewart (editor)

\section{Macro-Policies for Appropriate Technology in Developing Coun- tries}

Westview Press, Boulder, CO, USA, 325 pp., $\$ 29.85$

With this collection of essays, the appropriate technology movement joins the search for a better policy environment. Although in parts of the book the jargon of appropriate technology makes it appear to be regarded more as an end than a means, good sense mostly prevails. Appropriate technology, aimed at promoting employment and equity, is defined here by its small scale, labor intensity (high labor/ output and low capital//abor ratios), use of local materials, and output of "appropriate" products that are low cost, with minimal packaging, less standardization, and, as a result, perhaps of lower quality.

$A$ theme repeated throughout is the bias towards more sophisticated mechanized solutions shared by rich entrepreneurs, western machinery manufacturers, their agents in developing countries, and governments that want "modernity." Other groups lose from these technical solutions, but would gain from "more appropriate" ones. While the analysis of these gains and losses gropes for better methods of measurement, they are described plausibly and clearly. Few good ways are proposed, however, to overcome biases so rooted in existing power structures. The collection assesses technology choices widely across sectors and social settings, opening the subject for further scrutiny rather than providing definitive answers about what policies to use.

Among individual papers, Ashok Rudra, in an otherwise ill-conceived attack on Green Revolution technology in India, is right in criticizing subsidized farm tractors, for which no good case can be made--a view also espoused by the World Bank's recent policy paper on agricultural mechanization. Stephen Biggs and Jon Griffith are persuasive about reducing subsidies on mechanized irrigation methods in Bangladesh, and eliminating taxes on their favored technology, the manually operated shallow tubewell.

It is interesting to see a book on appropriate technology embracing the axial flow paddy thresher, which, as Bart Duff's lucid account shows, has thrown a lot of people out of work. It makes the point that appropriateness is relative: the thresher is judged "socially beneficial" in Thailand where policy distortions in its favor were few and labor not in surplus, but "inappropriate" in the Philippines where the reverse was true on both counts. Whether international research should develop such technologies is answered ambivalently.
Jeffrey James discovered that in spite of different ideologies, development goals, and macro environments, parastatals in Kenya and Tanzania chose similar developed country technologies for making textiles, ceramics, detergents, shoes, and processing cashew and sugar. This happened because the parastatals were driven to western financiers. To deal with these biases, he advocates restoring incentives for efficiency, seeking finance from developing countries and multilateral sources, getting independent technical advice, and being wary about choosing technologies on the basis of their making "export quality" goods.

Raphael Kaplinsky compares two distinct sugar refining techniques in Indian and Kenyan settings, while Gustav Ranis and Frances Stewart assess implications for appropriate technology of rural growth linkages in Taiwan and the Philippines. Finally, Philip Maxwell, using examples from Latin America, describes how crucial are in-house resources for the hundreds of adaptations that firms have to make in manufacturing technologies. The initial choice of technology is followed by patterns of technical change which may be more or less "appropriate" for their context.

Graeme Donovan

\section{BOOKS in brief}

Paolo Savona and George Sutija (editors)

\section{Strategic Planning in International Banking}

St. Martin's Press, New York, 1986, xiv + 229 pp., $\$ 32.50$.

While the use of strategic planning in industry has grown in recent years, its application in international banking has lagged and little has yet been written on this subject. This book, a useful collection of papers presented at the International Conference on Strategic Planning in International Banking held at Rome in May 1984 , is a first step toward filling that void. Most of the contributions concentrate on current problems facing international banks, especially their loans to developing countries, rather than on the more theoretical aspects of strategic planning. One exception is the article by Guttentag and Herring on "Strategic Planning by International Banks to Cope with Uncertainty," which breaks some new ground.

Photo credits: Photographs on pages $5,11,15,34$, and 38 by R. Townsend; pages 30 and 42 by D. Zara; and on page 26 by $M$. lannacci.
Abdul Wahhab Ibrahim

\section{Obstacles to Development in the Third World}

\section{A Study of the Case of Egypt; A Sociological} View

Second Edition (Arabic only), Arab Renaissance House, Cairo, $1985,496 \mathrm{pp}$.

This study, which originated as a doctoral dissertation at Cairo University, sets out to investigate obstacles to development identified inter alia as neglect of economic issues by the ruling elites and "colonial" exploitation. The study uses the class structure of Egyptian society as a key variable to explain its development experience. It relies on a survey of $\mathbf{4 5 0}$ persons (the overwhelming majority of whom are described as poor) from two villages near Cairo where agriculture land is fragmented and the "rich" are defined as owning more than ten acres each. The author throughout uses Marxist concepts of class, and finds fault with the government's planning efforts which, in his view, appear to have failed to ensure true participation by the masses in development.
Richard L. Kitchen

\section{Finance for the Developing Countries}

John Wiley \& Sons, New York, xviii + 365 pp., \$48.95

Although some 80 percent of investment in developing countries is financed from domestic sources, external finance is a critical element in the efforts of these countries to develop their economies. The issues and the conditions that they face are broadly similar, but the need for external financing and the relative strength of individual developing countries in tapping the sources of such financing may vary. This book adopts a textbook approach to explaining the theory and practice of financial markets and institutions. While it runs the risk of becoming out of date in the rush of events surrounding the international debt situation and the role of multilateral institutions in providing finance for development and stabilization programs, this volume provides a handy guide to the kaleidoscopic world of high finance. 


\section{In defense of import substitution}

In Guy Pfeffermann's article, “Economic Crisis and the Poor in Some Latin American Countries," in the June issue he writes, "The countries of the region have made significant efforts to adjust" (to the economic difficulties of the 1980s). He continues, “. . . export and efficient import-substitution projects have been undertaken." We all realize that import substitution is not popular among many World Bank and IMF authors, so it is to be welcomed that the possibility at least of "efficient import-substitution projects" is being recognized. However, even now there seems to be an imbalance in that export projects are welcomed without qualification, whereas import-substitution projects have to be "efficient." Do not export projects also have to be efficient? Are there no inefficient export projects? To this reader at least the passage suggests an unjustified tipping of the scales against import substitution.

At the end of the same paragraph, the article displays a similar imbalance by stating, ". . . adjustment so far has been achieved largely through import cuts rather than through employment-creating export expansion." Once again, the innocent reader may conclude that export expansion is employment- creating whereas import substitution is not. Is there any justification for this implication? I would doubt it.

Perhaps I may be allowed to link my comment with the very interesting article by Mohsin Khan and Nadeem Ul Haque entitled "Capital Flight from Developing Countries" in the March issue. While this article relates its figures on capital flight to the international debt problem, one could also relate them to export earnings. Like debt service, capital flight seems to constitute a significant tax on export earnings of Latin American countries. Is it not an advantage of foreign exchange saving through import substitution that it lends itself less easily than export earnings to capital flight?

\section{H.W. Singer \\ Brighton, England}

\section{Guy Pfeffermann responds:}

I fully agree with Professor Singer that efficient import substitution is as desirable as exports as a means to achieve resumed economic growth. In fact, "exports" should be read as shorthand for "exports and efficient import substitution."

In Latin America, however, the scope for further efficient import substitution may be limited. The Latin American share of world

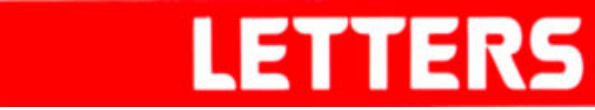

trade had already been halved between the 1950 s and the debt crisis. There remains some scope for efficient import substitution in agriculture, and the World Bank has, in fact, been urging countries to eliminate "negative protection" in that sector.

Unfortunately, industrial import substitution is not often "efficient." This is because in most countries, an array of import barriers makes inefficient import substitution far more profitable than exports. In such countries, trade policy reform aimed at putting production for export on an equal footing with that to substitute imports is the most effective way to achieve resumed growth and employment creation. Exports do not face the limits to growth inherent in small domestic markets, and can therefore generate sustained employment growth.

As for the suggestion that exports facilitate capital flight, this is hardly supported by evidence from Latin America. Brazil experienced rapid export growth during the 1970s and early 1980 s without substantial capital flight.

\section{Staff Papers of the International Monetary Fund}

A quarterly publication, Staff Papers publishes material on current monetary and financial issues. The topics covered are relevant for a broad audience of government officials, professional economists, and all those interested in international monetary economics. The September 1987 issue, for instance, will publish articles on, among others, international capital mobility and saving-investment correlations, hyperinflation and stabilization policy in Argentina and Israel, devaluation and monetary policy in developing countries, and the impact of demographic change on social security financing.

The subscription for Staff Papers is US $\$ 15.00$ a volume or the approximate equivalent in the currencies of most countries. Four numbers constitute a volume. Single copies may be purchased at $\$ 4.00$. Special rates to university libraries, faculty members, and students are $\$ 7.50$ a volume; $\$ 4.00$ a single copy.

Subscriptions and orders should be sent to:

Publication Services - Box No. A-873

International Monetary Fund - Washington, D.C. 20431, U.S.A.

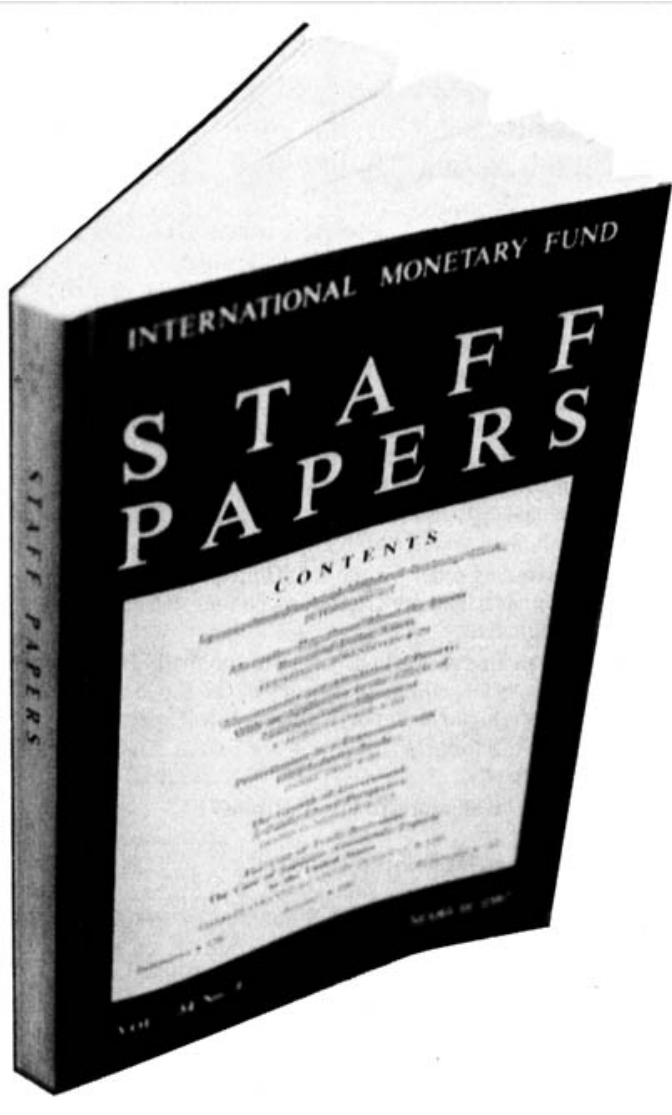

Telephone number: (202) 623-7430 - Cable address: Interfund 


\title{
From the World Bank and Oxford University Press World Development Report 1987
}

\author{
Featuring - A concise review of recent trends in the world economy \\ - A special report on the role of foreign trade in \\ industrialization \\ - World Development Indicators for 128 countries \\ 298 pages $/ 8 \times 10 \frac{1}{2}$
}

\section{And for the first time...}

World Development Indicators on machine-readable diskettes for use in your personal computer

\section{Other studies of industrialization in developing countries from the World Bank and Oxford University Press}

\section{China's Industrial Reform}

Gene Tidrick and Chen Jiyuan

Based on unprecedented access to information from Chinese enterprises, this book analyzes China's far-reaching industrial reforms. It presents the results of a unique collaboration of Chinese and Western economists, whose analysis is already influencing the course of ongoing reforms and has important implications for other socialist countries and other developing countries.

384 pages/hardcover/61/6 x 91/4 ISBN 0-19-520592-8/US\$35.00
Industrialization and Growth: A Comparative Study

Hollis Chenery, Sherman Robinson, and Moshe Syrquin Analyzes a variety of patterns of industrial developmentranging from the export-led growth of the Republic of Korea and Taiwan to the more inward-oriented growth of Colombia and Turkey-that have emerged in the postwar period.

400 pages/hardcover/61/8 x 91/4 ISBN 0-19-520547-2/US\$29.95

\section{Productivity, Technology, and Industrial Development \\ A Case Study in Textiles \\ Howard Pack \\ 208 pages/hardcover $/ 61 / 8 \times 91 / 4$ ISBN 0-19-520543-X/US\$22.50 \\ Small Manufacturing Enter- prises: A Comparative Study of India and Other Economies \\ Ian M.D. Little, Dipak Mazumdar, and \\ John M. Page, Jr. \\ About 275 pages/hardcover/61/8 x $91 / 4$ ISBN 0-19-520619-3/US\$27.50 \\ Success in Small and Medium- Scale Enterprises \\ The Evidence from Colombia \\ Mariluz Cortes, Albert Berry, and Ashfaq M. Ishaq \\ 296 pages/hardcover/61/8 x $91 / 4$ \\ ISBN 0-19-520593-6/US\$27.50}

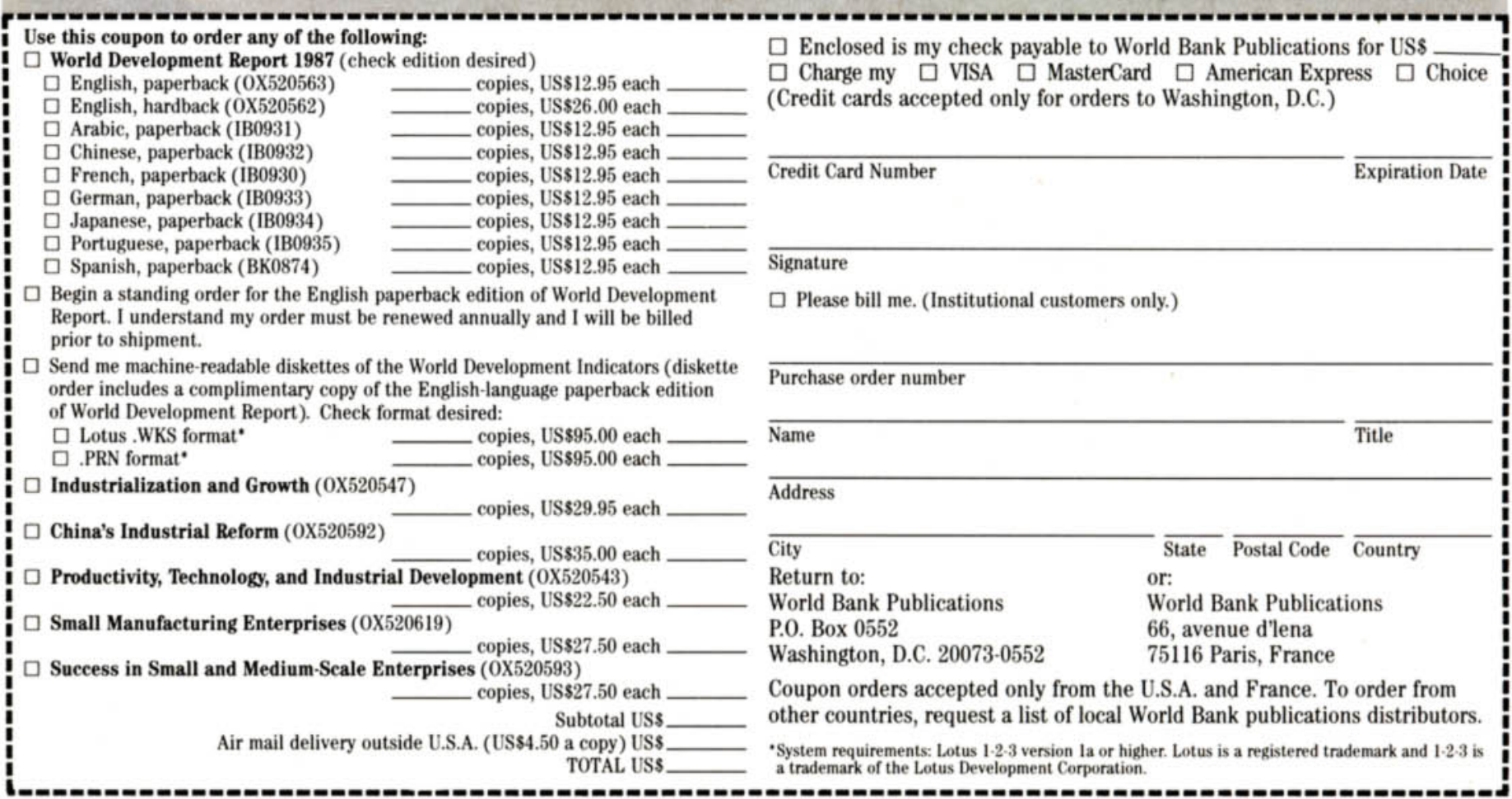

